RENATO ROMERO POLILLO

\title{
ALIENAÇÃO FIDUCIÁRIA DE BENS IMÓVEIS
}

\author{
DissertaÇ̃̃o DE MESTRAdO
}

Orientador: Prof. Titular CARlos Alberto Dabus Maluf

FACULDADE DE DIREITO DA UNIVERSIDADE DE SÃO PAULO

SÃO PAULO

2013 
RENATO ROMERO POLILLO

\section{ALIENAÇÃO FIDUCIÁRIA DE BENS IMÓVEIS}

Dissertação apresentada ao Programa de Pós-Graduação em Direito Civil da Faculdade de Direito da Universidade de São Paulo, como requisito parcial para obtenção do título de Mestre em Direito Civil.

ORIENTADOR: Prof. Titular CARlos Alberto Dabus Maluf

FACULDADE DE DIREITO DA UNIVERSIDADE DE SÃO PAULO

SÃO PAULO

2013 


\title{
FOLHA DE APROVAÇÃO
}

\author{
Candidato: $\quad$ Renato Romero Polillo \\ Natureza: Dissertação de Mestrado \\ Instituição: $\quad$ Faculdade de Direito da Universidade de São Paulo \\ Objetivo: \\ Exigência parcial para a obtenção do título de Mestre em Direito \\ Prof. Orientador: \\ Concentração: \\ Carlos Alberto Dabus Maluf \\ Direito Civil \\ Data da banca:
}

Prof. Carlos Alberto Dabus Maluf (orientador)

Professor:

Titulação:

Instituição: Universidade de São Paulo

Professor:

Titulação:

Instituição: 


\section{Dedicatória}

À minha esposa, Luana, pelo amor incondicional. 


\section{Agradecimento}

Ao meu pai, por ter me transmitido o amor pela advocacia, e ao Prof. Carlos Alberto Dabus Maluf, pelo conhecimento compartilhado e pela paciência durante a elaboração deste trabalho. 


\section{RESUMO}

Esta dissertação tem como objetivo principal a análise da alienação fiduciária de bens imóveis regulada pela Lei $\mathrm{n}^{\circ}$ 9.514/97 e os seus efeitos a partir do seu registro no competente Registro de Imóveis. Essa modalidade de garantia real foi introduzida em nosso ordenamento na década através da Lei $\mathrm{n}^{\circ} 4.728 / 65$, alterada e complementada pelo Decreto-Lei no 911/69, que tratava do financiamento de bens de consumo duráveis. Dada a bem sucedida experiência com aludida lei federal aliada à escassez de moradia que assola o País, a alienação fiduciária de bens imóveis surgiu como uma solução para combater tal problema social e, ao mesmo tempo, fomentar o crescimento econômico, com a geração de empregos na indústria de construção civil. Com o registro do contrato de alienação fiduciária perante o competente Registro de Imóveis, a propriedade fiduciária é constituída. Enquanto a propriedade fiduciária é a garantia real, o contrato de alienação fiduciária em garantia é o título para sua constituição. Inexistido o registro do mencionado contrato, inexiste garantia real. A propriedade fiduciária de bens imóveis representou verdadeira revolução no mercado imobiliário, especialmente no campo das garantias reis. Por meio da propriedade fiduciária, o credor-fiduciário recebe a propriedade resolúvel e limitada do imóvel, bem como a sua posse indireta, ao passo que o devedor-fiduciante recebe a posse direta do imóvel, podendo dele usufruir por sua conta e risco enquanto estiver adimplente. Em caso de inadimplemento do devedor-fiduciário, a Lei $\mathrm{n}^{\circ}$ 9.514/97 autoriza o credorfiduciário a alienar o imóvel em público leilão extrajudicial, desde que observados certos procedimentos. Apesar desta fórmula de satisfação do crédito ainda ser controversa na doutrina e na jurisprudência, a posição majoritária dos tribunais é no sentido de que o leilão extrajudicial atende aos princípios constitucionais do contraditório e da ampla defesa. Tal fato tem contribuído substancialmente para a crescente utilização desta nova modalidade de garantia real.

PALAVRAS-CHAVE: alienação fiduciária de imóveis - propriedade fiduciária - garantia real - Registro de Imóveis 


\begin{abstract}
The goal of this dissertation is to review the contract of fiduciary alienation of real estate governed by Federal Law No. 9.514/97 and its effects after its registration before the real estate registry. Such type of security was introduced in the Brazilian legal system in the 60's by Federal Law No. 4.728/65, modified and complemented by Decree-Law No. $911 / 69$, which regulates the fiduciary alienation of durable goods. Based on the success achieved with that Federal Law and the necessity of covering the lack of residential properties in Brazil, the fiduciary alienation appeared as a solution to face such social issue and, at the same time, stimulate the economic growth with the creation of new employments in the civil construction industry. By the act of recording the contract of fiduciary alienation before the real estate registry, the fiduciary ownership of real estate (propriedade fiduciária sobre bens imóveis) emerges. While the fiduciary ownership is a type of security, the contract of fiduciary alienation is the title necessary to constitute that security. If the contract of fiduciary alienation is not registered before the real estate registry, there is no security. The fiduciary ownership of real estate represented a revolution in the Brazilian real estate market, mainly on the field of securities. Through the fiduciary ownership of real estate, the fiduciary/trustee (credor-fiduciário) receives the title of the property object of the security as well as its indirect possession, and, on the other hand, the fiduciary agent (devedor-fiduciante) receives the direct possession over the property and is entitled to the right of using the real estate by its own risk while he performs his obligations. In case the fiduciary agent fails to accomplish his obligations of paying the debt, Federal Law No. 9.514/97 allows the trustee to recover its credit with the sale of the property at an extrajudicial public auction since all procedures provided in Law are duly respected. Although this formula of satisfying the trustees' credit is still discussed by doctrine and case law, the majority position of case law points out the constitutionality of the public auction regulated by Federal Law No. 9.514/97 since it observes the constitutional commandment of due process of law. This fact has contributed substantially for the increasing use of this new type of security.
\end{abstract}

\title{
KEY WORDS: fiduciary alienation od real estate - fiduciary ownership of real estate - security - estate registry
}




\section{SUMÁRIO}

INTRODUÇÃ̂............................................................................................ 1

\section{BREVES NOTAS HISTÓRICAS......................................................4}

1.1. Importância da análise histórica da fidúcia ............................................... 4

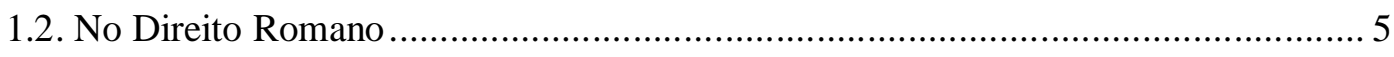

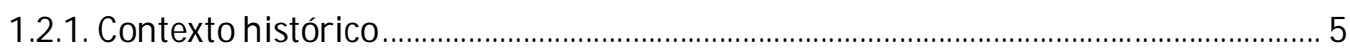

1.2.2. Conceito de fidúcia do tipo romano................................................................................ 6

1.2.3. A constituição da fidúcia e as suas espécies .................................................................... 8

1.2.4. Elementos da fidúcia ...................................................................................................11

1.2.5. A actio fiduciae ............................................................................................................... 13

1.2.6. A decadência da fidúcia como garantia real ......................................................................14

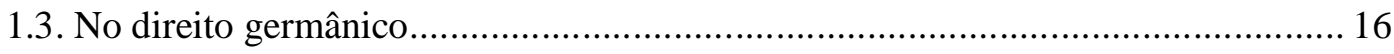

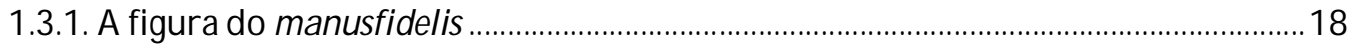

1.3.2. A figura do Salmann ................................................................................................................19

1.3.3. A figura do Treuhand ........................................................................................................... 19

1.3.4. A distinção entre a fidúcia do tipo romano e a do tipo germânico ...............................20

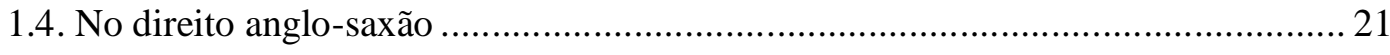

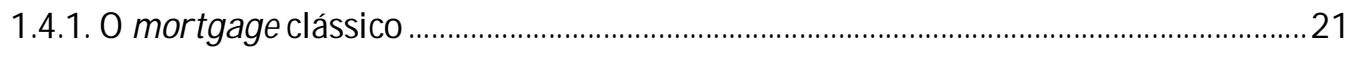

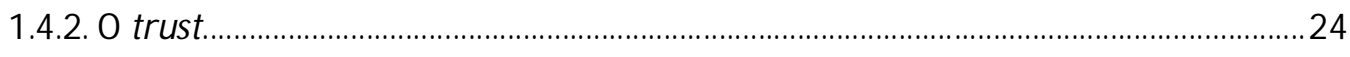

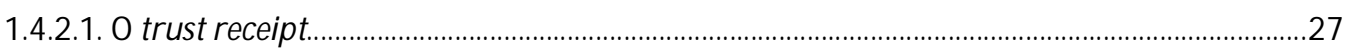

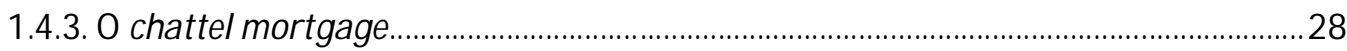

\section{O DECLÍNIO DA HIPOTECA COMO GARANTIA REAL................30}

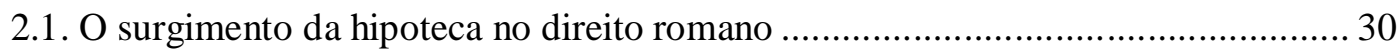

2.2. O surgimento e o declínio da hipoteca no direito brasileiro............................... 31

2.3. A propriedade fiduciária como opção de garantia real ....................................... 36

\section{O PERFIL DOGMÁTICO DA ALIENAÇÃO FIDUCIÁRIA DE BEM

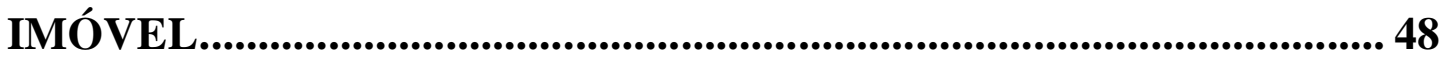

3.1. A estrutura da alienação fiduciária de bens imóveis ...................................... 48 
3.2. A definição de alienação fiduciária de bem imóvel ............................................. 49

3.3. O negócio fiduciário e institutos afins .............................................................. 50

3.3.1. A alienação fiduciária e o negócio fiduciário ...................................................................51

3.3.2. O negócio fiduciário e o negócio simulado .........................................................................55

3.3.3. O negócio fiduciário e o negócio indireto ..........................................................................59

3.3.4. O negócio fiduciário e a venda com reserva de domínio ...................................................61

3.3.4. O negócio fiduciário e o compromisso de compra e venda..............................................64

3.3.4.1. Breves notas sobre o compromisso de compra e venda ...............................................................64

3.3.4.2. A natureza jurídica do compromisso de compra e venda........................................................67

3.3.4.3. As principais obrigações do compromissário comprador e do promitente vendedor ......68

3.3.4.4. Distinção entre alienação fiduciária e o compromisso de compra e venda.............................69

3.4. A natureza jurídica da alienação fiduciária de bens imóveis ............................... 71

3.4.1. A alienação fiduciária de bem imóvel é contrato bilateral sem cunho obrigatório

. .72

3.4.2. A alienação fiduciária imobiliária é contrato típico e causal .........................................74

3.4.3. A alienação fiduciária imobiliária é contrato acessório ....................................................76

3.4.4. A alienação fiduciária de bem imóvel como título constitutivo da propriedade

fiduciária mediante registo .79

\section{REQUISITOS DE VALIDADE DO CONTRATO DE ALIENAÇÃO FIDUCIÁRIA DE BEM IMÓVEL.........................................................81}

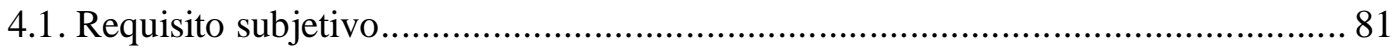

4.1.1. A legitimação do condômino para alienar fiduciariamente sua parte indivisa .......85

4.2. Objeto do contrato de alienação fiduciária de bem imóvel .................................. 86

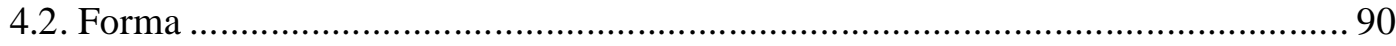

\section{A PROPRIEDADE FIDUCIÁRIA ............................................... 94}

5.1. A natureza jurídica da propriedade fiduciária ................................................... 94

5.2. A indivisibilidade da propriedade fiduciária .................................................. 101

5.3. O desdobramento da posse e suas consequências............................................. 102

5.4. Direitos e obrigações do devedor-fiduciante e do credor-fiduciário .................... 104

5.5. A cessão da posição contratual .................................................................. 107

5.5.1. A cessão da posição do credor-fiduciário ...................................................................... 107 
6. A EXTINÇÃO DA PROPRIEDADE FIDUCIÁRIA .......................... 110

6.1. O adimplemento da obrigação principal .................................................... 110

6.2. O inadimplemento da obrigação principal ..................................................... 111

6.3. O inadimplemento da obrigação principal ................................................... 113

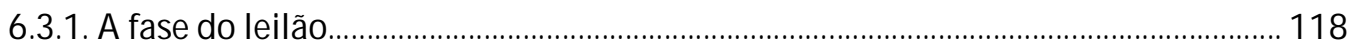

7. QUESTÕES CONTROVERTIDAS .................................................. 123

7.1. A discussão sobre a constitucionalidade do leilão extrajudicial.......................... 123

7.2. O artigo 53 do Código de Defesa do Consumidor........................................... 129

\section{BREVES CONSIDERAÇÕES SOBRE O SISTEMA NORTE- AMERICANO E A CRISE IMOBILIÁRIA ........................................... 134 \\ 8.1. A figura do mortgage no direito norte-americano ...................................... 136

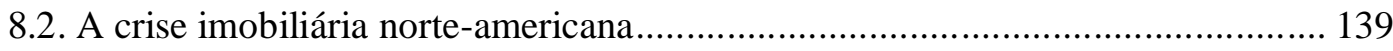

CONCLUSÃO..................................................................................... 144

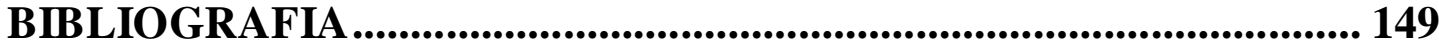




\section{INTRODUÇÃO}

O objetivo desta dissertação é examinar o instituto da alienação fiduciária de bens imóveis e seus efeitos nos campos do direito das obrigações, do direito real e do Registro de Imóveis, sem, contudo, ter a pretensão de esgotar o tema.

A partir da necessidade de se prevenir os riscos de inadimplemento contratual e de reforçar o cumprimento das obrigações, em que há um período de tempo entre a sua conclusão e o seu cumprimento, surgiram as garantias contratuais, que tanto podem ser reais como pessoais.

No caso específico da alienação fiduciária, ela teve sua origem no direito romano por meio da fidúcia e logo se tornou a modalidade de garantia real preferida pelos credores. Apesar de aparentemente inexistir qualquer relação e/ou influência do direito romano, o direito germânico e direito anglo-saxão também desenvolveram institutos de garantia real semelhantes à fidúcia.

No Brasil, com o desenvolvimento econômico no século XIX, decorrente do crescimento do mercado cafeicultor aliado ao início da contratação de mãode-obra assalariada para trabalhar nas lavouras, surgiu a necessidade de constituir a propriedade privada de imóveis para que ela pudesse ser destinada à garantia de obrigações relacionadas à concessão de financiamentos principalmente para os cafeicultores.

Nesse contexto, em 21 de outubro de 1843, foi introduzida em nosso ordenamento a figura da hipoteca por meio da Lei Orçamentária $n^{\circ}$ 317/1843, posteriormente ser regulamentada pelo Decreto $n^{\circ} 482 / 1846$, que, nos seus trinta e três artigos, tratou, dentre outros tópicos, do local de registro da hipoteca, da pessoa responsável em requerer o registro e em executá-lo, dos documentos necessários para registro da hipoteca, dos efeitos do registro.

A hipoteca acabou por se firmar como a principal modalidade de garantia real no direito brasileiro. Contudo, por força da crise pela qual as garantias reais tradicionais, em especial a hipoteca, passam ante a dificuldade na recuperação de crédito, o legislador verificou a necessidade de criar uma nova modalidade de garantia real capaz de atender aos anseios da sociedade.

Em razão da bem sucedida experiência com a alienação fiduciária em garantia de bens móveis criada pela Lei $\mathrm{n}^{\circ}$ 4.728/65, alterada e complementada pelo Decreto-Lei $\mathrm{n}^{\text {o }} 911 / 69$, o legislador optou por estender os princípios daquele texto 
normativo para os bens imóveis de modo a conferir maior proteção aos capitais envolvidos em financiamentos para aquisição de bens imóveis, editando, assim, a Lei nº 9.514/97.

Como será analisado no decorrer deste trabalho, a legislação confere à alienação fiduciária tratamento peculiar, na medida em que a propriedade do bem dado em garantia do cumprimento da obrigação é transferida ao credor-fiduciário pelo registro do contrato de alienação fiduciária perante o competente Registro de Imóveis, constituindo, assim, a propriedade fiduciária, esta, sim, garantia real.

Embora a transmissão da propriedade ao credor-fiduciário ocorra sob condição resolutiva, essa propriedade limitada o permite a alienar o imóvel em público leilão quando verificada a inadimplência do devedor-fiduciante e desde que observados os requisitos legais para consolidação da propriedade na sua pessoa. Em contrapartida, ao devedor-fiduciante cabe a posse direta do mesmo bem e a sua livre utilização, por sua conta e risco, sendo-lhe reservado o direito de ser restituído no pleno domínio do imóvel quando adimplida integralmente a dívida.

Como se vê, a preferência pela adoção de tal instituto nos negócios jurídicos praticados no mercado imobiliário deve-se à sua singular efetividade na recuperação do capital financiado, sobretudo em caso de falência ou insolvência do devedor, seja pela sua eficácia funcional, seja pela sua classificação sobre os demais créditos concursais.

Apesar de parte da doutrina questionar a constitucionalidade do leilão extrajudicial e a incidência do artigo 53 do Código de Defesa do Consumidor nos contratos de alienação fiduciária de imóveis, conforme será analisado adiante, fato é que, com o advento da Lei $n^{\circ}$ 9.514/1997, a alienação fiduciária tornou-se a modalidade de garantia real preferida pelas instituições financeiras nos negócios jurídicos imobiliários, servindo para fomentar o crescimento econômico nacional, seja mediante a rápida recuperação de crédito, seja pela circulação de ativos mobiliários emitidos com lastro em créditos imobiliários.

Ademais, o grave déficit habitacional que tanto assola o País aos poucos vem sendo reduzido com a rápida e desburocratizada concessão de crédito principalmente aos cidadãos de baixa renda.

Por fim, o presente trabalho tece algumas considerações sobre o sistema norte-americano de garantia ao financiamento imobiliário e a crise imobiliária que atingiu os Estados Unidos nos idos de 2008, fazendo comparações pontuais entre as 
modalidades de financiamento daquele sistema com a alienação fiduciária em garantia de imóveis do direito brasileiro. 


\section{CAPÍTULO 1 BREVES NOTAS HISTÓRICAS}

\subsection{Importância da análise histórica da fidúcia}

O surgimento de determinado instituto jurídico é fruto de um longo e lento processo evolutivo da sociedade e não da vontade arbitrária do legislador. Por isso, a sua análise histórica auxilia sobremaneira a sua compreensão, ampliando a visão para a conjectura da qual aquela norma faz parte e não apenas para a letra fria da lei. Esse é o caso da alienação fiduciária, cujas origens remontam ao direito romano, com alguma influência do direito germânico e do direito anglo-saxão.

A fidúcia, tal como era chamada no direito romano, também se desenvolveu no direito germânico na figura do penhor de propriedade. Alfredo Buzaid, assinala que, por meio do referido instituto do direito germânico, "o devedor transferia ao credor a propriedade da coisa com as suas formas habituais, pactuando em conjunto a obrigação de restituí-la tão logo o devedor, no vencimento, tivesse solvido a dívida." ${ }^{1}$

Também há notícia de que o direito inglês contemplava o instituto da fidúcia na figura do mortgage clássico, pelo qual o devedor transferia a propriedade ao credor a título de garantia de um crédito. Como será demonstrado adiante, apesar da semelhança estrutural dos aludidos institutos, o mortgage clássico era dotado de uma peculiaridade no que concerne à condição resolutiva, que não estava presente na fidúcia do tipo romano.

Apesar de a fidúcia ter sido extinta pelo Corpus Iuris Civilis do século VI e não ter sido contemplada no Código Civil francês de 1804 nem no BGB de 1896 e nem no Código Civil brasileiro de 1916, conforme observa Luiz augusto Beck da Silva², a sua simplicidade e eficácia persistiram no tempo e serviram de mote para a sua introdução no direito brasileiro.

Não à toa, George Siqueira, um dos idealizadores da figura da alienação fiduciária do direito brasileiro, mencionou na justificativa de emenda ao projeto da Lei $\mathrm{n}^{\circ}$ 4.728/65, alterada e complementada pelo Decreto-Lei $\mathrm{n}^{\circ} 911 / 69$, apresentada por

\footnotetext{
${ }^{1}$ BUZAID, Alfredo. Ensaio sobre a alienação fiduciária em garantia. São Paulo: ACREDFI, 1969, p. 12. 2 SILVA, Luiz Augusto Beck da. Alienação fiduciária em garantia: história, generalidades, aspectos processuais, ações, questões controvertidas, legislação e jurisprudência. Rio de Janeiro: Forense, 1998, p. 7.
} 
intermédio do senador Jefferson de Aguiar perante o Senado Federal, que a criação e introdução da referida garantia real era inspirada no negócio fiduciário do tipo romano ${ }^{3}$.

Apesar da clara inspiração na fidúcia do tipo romano, diversos fatores externos acabaram por moldar a alienação fiduciária da forma que conhecemos hoje: a cultura, o contexto social na qual ela foi inserida, as necessidades e as características próprias da sociedade brasileira. Entretanto, pode-se afirmar que a essência da mais antiga modalidade de garantia real $^{4}$ permanece intacta: a transferência da propriedade ao fiduciário com escopo de garantia, obrigando-se este a restituir a coisa ao fiduciante quando verificado o pagamento do débito.

\subsection{No Direito Romano}

\subsubsection{Contexto histórico}

Embora a fidúcia consista na mais antiga modalidade de garantia real, seu aparecimento é impossível de precisar por ter sido um instituto presente no seio da sociedade romana desde os seus primórdios, muito antes da sua inserção no sistema jurídico romano como dispositivo legal.

Segundo Otto de Sousa Lima ${ }^{5}$, apesar dos vestígios da efetiva existência da fidúcia no direito romano, diversos fatores contribuem para impedir a exata identificação do seu nascedouro por inexistirem "normas propriamente jurídicas" naquela época. O homem romano primitivo, absorvido pela vida coletiva entre os membros de sua família e da sua tribu, desempenhava suas atividades subordinado apenas aos usos e às regras de cunho moral, sem qualquer caráter coativo. Esse é o mesmo entendimento de Aderbal da Cunha Gonçalves ${ }^{6}$, que, com base em Maynz, Marezoll e Enneccerus, afirma que, antes de ser mencionada na legislação, a fidúcia foi uma "figura do direito costumeiro, nascida da necessidade de uma melhor e mais efetiva garantia para o crédito, sendo anterior ao penhor."

\footnotetext{
${ }^{3}$ ALVES, José Carlos Moreira Alves, Da alienação fiduciária em garantia, 3. ed., rev., atual. e aum., Rio de Janeiro: Forense, 1987, p. 24.

${ }^{4}$ ALVES, José Carlos Moreira. Direito Romano - História do Direito Romano, Instituições do Direito Romano: A) Parte geral; B) Parte especial: Direito das coisas. $3^{\mathrm{a}}$ ed. rev. acres. Rio de Janeiro: Forense, 1971, p. 388.

${ }^{5}$ LIMA, Otto Sousa, Negócio Fiduciário. Tese para concurso à cátedra de Direito Civil da Faculdade de Direito da Universidade de São Paulo. Universidade de São Paulo, São Paulo, 1959, p. 3.

${ }^{6}$ GONÇALVES, Aderbal da Cunha. Da propriedade resolúvel. São Paulo: Ed. Revista dos Tribunais, 1979, p. 214.
} 
Com o desenvolvimento da sociedade romana, as regras passaram a ser corporificadas em dispositivos legais, os quais foram posteriormente inseridos num sistema jurídico. Embora tal fato não seja capaz de precisar com exatidão o surgimento de determinado instituto, ao menos, ele serve para apontar o marco inicial da sua consolidação como norma legal. Esse é o caso da fidúcia que, apesar de largamente utilizada pelo romano primitivo, somente veio a ser cristalizada como dispositivo legal na Lei das XII Tábuas, concluída no ano de 450 a.C., conforme observa Alfredo Buzaid ${ }^{7}$, assinalando que a fidúcia é anterior ao pignus.

Num primeiro momento, a fidúcia lastreava-se apenas na lealdade e na honestidade do fiduciário, uma vez que inexistia qualquer tipo de sanção se ele, fiduciário, se recusasse a restituir a coisa ao fiduciante. Foi somente com a criação da Lei das XII Tábuas em 450 a.C. que a fidúcia veio ganhar a força de lei, cuja Tábua Sexta, cujo título De dominio et possessione assim dispunha: "Quum nexum faciet mancipiumque, uti língua nuncupassit, ita jus eto" ("Se alguém empenha a sua coisa ou vende em presença de testemunhas, o que prometeu tem força de lei.”).

Posteriormente, pelas Institutas de Gaio, confeccionada por volta de 161 d.C., a fidúcia surgiu como um pacto adjeto à mancipatio ou à in iure cessio, que eram modalidades de transferência da propriedade no direito romano. Também há indícios da presença da fidúcia no Digesto publicado em 533 d.C., que, no entanto, não deu continuidade ao seu desenvolvimento, pois, como observa Carlo Longo ${ }^{8}$, referido por Otto de Sousa de Lima, naquele momento, Justiniano a considerava um instituto antiquado. Tal fato já dava indícios de que a rigidez da fidúcia não mais atendia ao dinamismo das relações comerciais em Roma, o que abriu caminho para a sua futura substituição pela hipoteca e pelo penhor, garantias reais que dispensavam os inconvenientes causados ao devedor pela transmissão da propriedade ao credor, conforme será exposto adiante.

\subsubsection{Conceito de fidúcia do tipo romano}

Moreira Alves define a fidúcia como sendo um negócio jurídico pelo qual o fiduciante transferia a propriedade de uma coisa infungível ao fiduciário a título de

\footnotetext{
${ }^{7}$ BUZAID, op. cit., p. 7

${ }^{8}$ LIMA, op. cit., p. 10.
} 
garantia de uma obrigação e, por meio do pactum fiduciae, ajustava "a restituição da coisa, quando extinta a obrigação."9

\section{Mariano Martorell ${ }^{10}$ busca em Para Pietro Bonfante a definição de}

fidúcia:

una convención por la cual una de las partes (fiduciario), al recibir de la otra (fiduciante) una cosa en la forma de la mancipatio o la in iure cessio, asume la obligación de hacer uso de aquélla con un fin determinado, y, al menos por regla general, restituirla una vez logrado el fin.

Paulo Restiffe Neto e Paulo Sérgio Restiffe ${ }^{11}$ aduzem que a fidúcia romana implicava num contrato bilateral e gratuito lastreado na boa-fé, pelo qual o fiduciário recebia uma coisa do fiduciante por meio da mancipatio ou in iure cessio, "assumindo a obrigação de lhe dar uma certa destinação e de restituí-la quando exigida."

A definição de fidúcia confeccionada por Aderbal da Cunha Gonçalves $^{12}$ deixa clara a natureza dos dois elementos que a constituem: um do ponto de vista real, representado pela transmissão da propriedade ao fiduciário limitada, outro de caráter obrigacional, configurado pelo pactum fiduciae, que obrigava o fiduciário a restituir a coisa quando alcançado o objetivo pretendido pelas partes.

Após assinalar que a fidúcia surgiu após o penhor (pignus), Álvaro Villaça Azevedo ${ }^{13}$ a conceitua como sendo a máxima garantia conferida ao credorfiduciário, na medida em que este recebia a propriedade da coisa do devedor-fiduciante, na forma da mancipatio ou da in iure cessio, sendo obrigado a utilizá-la para uma determinada finalidade, restituindo-a com o advento do termo ou cumprimento da condição.

Semelhante entendimento era de Alfredo Buzaid ${ }^{14}$, que definia a fidúcia romana como a convenção pela qual o fiduciário, recebendo uma coisa do fiduciante, na forma da mancipatio ou in iure cessio, "assumia a obrigação de usá-la

\footnotetext{
${ }^{9}$ ALVES, op. cit., p. 389.

${ }^{10}$ MARTORELL, Mariano Navarro. La propriedad fiduciária - La fiducia histórica - Los modernos negócios fiduciários - La propriedad fiduciária. Barcelona: ed. Bosch, 1950, p. 28.

${ }^{11}$ RESTIFFE NETO, Paulo; RESTIFFE, Paulo Sérgio. Garantia fiduciária: manual teórico e prático com jurisprudência. $3^{a}$ ed., atual. e ampl. São Paulo: Ed. Revista dos Tribunais, 2000, p. 25.

${ }^{12}$ GONÇALVES, op. cit., p. 215.

${ }^{13}$ AZEVEDO, op. cit., p. 612.

${ }^{14}$ BUZAID, op. cit., p. 7-8.
} 
para determinado fim e pelo menos, de ordinário, de restituí-la uma vez alcançado o objetivo."

A confiança (fides) e a boa-fé representam o ponto comum dentre as definições de fidúcia acima indicadas, porquanto somente restava ao fiduciante confiar na boa-fé do fiduciário quando da celebração da fidúcia. Afinal, ao firmar a fidúcia, o fiduciante assumia o risco de um eventual abuso de direito pelo fiduciário, sem que dispusesse de qualquer instrumento capaz de obrigá-lo a restituir o bem, restando apenas pleitear indenização por perdas e danos de natureza estritamente pessoal.

\subsubsection{A constituição da fidúcia e as suas espécies}

Dentre os dispositivos legais supracitados, as obras de Gaio é que apresentam maior precisão ao definir o conceito de fidúcia, indicando a forma pela qual a fidúcia era constituída no direito romano, as suas espécies, finalidades e efeitos, bem como as ações que a tutelavam.

O $§ 59$ do Commentarius Secundus ${ }^{15}$ das Institutas de Gaio apontava a necessidade da fidúcia ser pactuada acessoriamente à mancipatio ou à in iure cessio, que eram modos de aquisição de propriedade a título derivado no direito romano. Esse pacto adjeto era denominado pactum fiduciae e tinha como objetivo estabelecer a obrigação do credor-fiduciário de restituir a coisa ao devedor-fiduciante quando adimplido pagamento do débito, sem, no entanto, estipular qualquer sanção ao credor-fiduciário caso ele viesse a descumprir sua obrigação. Afinal, na concepção do direito romano arcaico, o fiduciário era proprietário pleno da coisa, inexistindo qualquer limitação ao seu direito de usar, fruir e dispor da coisa. Como será exposto adiante, ao devedor-fiduciante restava tão somente pleitear indenização por perdas e danos contra o credor-fiduciário.

Segundo Moreira Alves ${ }^{16}$, a mancipatio era aplicada somente para transmissão de propriedade sobre a res mancipi e se tratava de um negócio jurídico solene, iuris civilis, que era processada na presença de cinco testemunhas, de um portabalança, do alienante e do adquirente, quem devia pronunciar as seguintes palavras

\footnotetext{
${ }^{15}$ Adhuc etiam ex aliis causis sciens quisque rem alienam usucapit; nam qui rem alicui fiduciae causa mancipatio dederit vel in jure cesserit, si eandem ipse possederit, potest usucapere, anno scilicet, soli si sit. Quae species usucapionis dicitur usureceptio, quia id, quod aliquando habuimus, recipimus per usucapionem.

${ }^{16}$ ALVES, op. cit., p. 338-339.
} 
perante todos: "Hunc ego hominem ex iure Quiritium meum esse aio isque mihi emptus esto hoc aere aeneaque libra." (Declaro que este homem é meu, segundo o direito dos Quirites, porque o comprei com este bronze e com esta balança). Dita tal fórmula, o adquirente batia num dos pratos da balança com um pedaço de bronze e o entregava ao alienante a título de preço. Concluído esse processo, a transferência da coisa era consolidada.

No que concerne à in iure cessio, José Cretella Júnior ${ }^{17}$ assinala que esta modalidade de aquisição de propriedade poderia ser utilizada tanto na aquisição de res mancipi quanto na de res nec mancipi, consistindo numa transmissão solene pela qual o adquirente reivindicava a propriedade da coisa abandonada pelo alienante perante um magistrado proferindo uma fórmula específica. Dada a palavra ao alienante, ele nada dizia, resultando, pois, na adjudicação da coisa ao adquirente pelo pretor, por força da confissão simulada.

Otto de Sousa Lima ${ }^{18}$ aponta a dúvida entre diversos autores acerca da possibilidade da transmissão da propriedade na fidúcia ser feita pela traditio, ressalvando que a posição majoritária da doutrina afasta a traditio como meio de transmissão fiduciária de propriedade com base nas Institutas de Gaio ${ }^{19}$.

$\mathrm{O} \S 60$ do Commentarius Secundus ${ }^{20}$ das Institutas de Gaio indica a existência de duas espécies de fidúcia: a fiducia cum creditore e a fiducia cum amico.

A fiducia cum amico foi a primeira espécie de fidúcia do tipo romano. Por meio deste instituto, um amigo transferia a propriedade da coisa a outro por certo período de tempo a título de empréstimo de uso ou até que cessassem as circunstâncias que ameaçavam o regular exercício do direito de propriedade, como, por exemplo, perturbações políticas em Roma, uma longa viagem ou risco de perecer numa guerra. Essa modalidade de fidúcia não tinha como escopo a garantia de uma obrigação, mas, sim, de proteção do patrimônio pelo fiduciante, que, confiando na

\footnotetext{
${ }^{17}$ CRETELLA JÚNIOR, José. Curso de direito romano: o direito romano e o direito civil brasileiro no Novo Código Civil. 30ª ed., rev., aum. Rio de Janeiro: Forense, 2007, p. 144.

${ }^{18}$ LIMA, op. cit., p. 68.

${ }^{19}$ Nam si tibi rem mancipi neque mancipavero neque in iure cessero, sed tantum tradidero, in bonis quidem tuis ea res efficitur, ex iure Quiritium vero mea permanebit, donec tu eam possidendo usucapias; semel enim impleta usucapione proinde pleno iure incipit, id est et in bonis et ex iure Quiritium, tua res esse, as cie a mancipata vel in iure cessa esset (II, § 41).

${ }^{20}$ Sed cum fiducia contrahitur aut cum creditore pignoris jure, aut cum amico, quod tutius nostrae res apud eum essent, si quidem cum amico contracta sit fiducia, sane omni modo competit ususreceptio; si vero cum creditore, soluta quidem pecúnia omni modo competit, nondum vero soluta ita demum competit si neque conduxerit eam a creditore debitor neque precário rogaverit ut eam rem possidere liceret; quo casu lucrativa usucapio competit.
} 
lealdade e honestidade do amigo fiduciário, a ele alienava o bem até que o risco de perdê-lo sobrestivesse.

Otto de Sousa Lima ${ }^{21}$, com apoio em Franceschelli, observa que a fiducia cum amico tinha um valor político e jurídico: enquanto o primeiro se configurava quando a fiducia cum amico era firmada em situações de incerteza e insegurança, como guerras, ataques, etc., com o objetivo de assegurar a defesa e integridade dos bens transferidos ao fiduciário, o segundo se verificava quando a transferência visava à proteção de um bem objeto de uma expropriação, por exemplo, fornecendo ao fiduciário um meio mais forte, enérgico e seguro (a propriedade) para defendê-lo.

A fiducia cum amico abriu caminho para o desenvolvimento da fiducia cum creditore e, como consequência, das demais garantias reais que vieram a surgir posteriormente - penhor e hipoteca. Por isso, é considerada a modalidade percussora para o desenvolvimento da sociedade romana, colocando-a em verdadeira sintonia com o direito.

É clara a semelhança entre a fiducia cum amico e os institutos do comodato e do depósito. Contudo, tais institutos não se confundem (até porque foram criados em momentos distintos): enquanto na fiducia cum amico há efetiva alienação do bem pelo fiduciante ao fiduciário, no comodato e no depósito, tal fato não ocorre, remanescendo a propriedade com o comodante ou com o depositante a depender do caso, que, por sua vez, transfere tão somente a posse da coisa ao comodatário ou depositário.

A fiducia cum creditore, por sua vez, possuía caráter assecuratório, na medida em que o devedor-fiduciante transferia a propriedade da coisa ao credor-fiduciário com o objetivo de garantir o pagamento de uma dívida por meio da mancipatio ou da in iure cessio. O credor-fiduciário se obrigava a restituir a propriedade da coisa ao devedor-fiduciante assim que o débito fosse integralmente quitado por força do pactum fiduciae. A fiducia cum creditore podia incidir tanto sobre bens móveis quanto imóveis e justamente por ter como escopo a garantia do pagamento da dívida contraída pelo devedor-fiduciante, pode-se afirmar que é a modalidade de garantia real que mais se assemelha com a alienação fiduciária em garantia do direito brasileiro.

${ }^{21}$ LIMA, op. cit., p. 95. 
Se por um lado a fiducia cum creditore representava excelente garantia ao credor, que se tornava proprietário pleno da coisa dada pelo devedor, por outro, essa operação fiduciária implicava em sérios inconvenientes para o devedor, que era privado de seus próprios bens e, pior, não mais podia obter novos créditos.

Não obstante tais inconvenientes e o surgimento de novas garantias reais, a fiducia cum creditore continuou sendo utilizada por conta da transferência da propriedade pela mancipatio ou pela in iure cessio, que asseguravam duas características essenciais ao bom funcionamento do sistema de crédito real: a publicidade e a especialização.

Por esses motivos, com base em Grassetti e Siebert, Martorell ${ }^{22}$ chama a fiducia cum creditore de "egoísta", por ser instituída com base no interesse do fiduciário, ao passo que denomina a fiducia cum amico como "altruísta", já que ela servia ao interesse do devedor.

Luiz Augusto Beck da Silva ${ }^{23}$ ressalva a existência de uma terceira modalidade de fidúcia: a fiducia remancipationis causa pelo qual o pater familias alienava seu próprio filho a outro pater familias, que, por seu turno, se obrigava a libertá-lo em seguida, visando obter o fim pretendido, qual seja, a emancipação do filho.

Por fim, Claude Reymond ${ }^{24}$ observa que a fidúcia romana também era utilizada no direito sucessório, que permitia ao testador designar um hereditário fiduciário, que deveria remeter a sucessão a um beneficiário. Como será exposto adiante, tal operação se assemelha ao trust do direito anglo-saxão.

\subsubsection{Elementos da fidúcia}

A fidúcia era composta por dois elementos: um de natureza real, consistente na transmissão da propriedade da coisa pelo fiduciante ao fiduciário através da mancipatio ou da in iure cessio, e outro de natureza obrigacional, qual seja, a obrigação do fiduciário de devolver a coisa quando resgatada a dívida pelo fiduciante.

O fiduciário recebia a propriedade plena da coisa, podendo dela usar, fruir e dispor. Este é o elemento de direito real na fidúcia. Entretanto, nem sempre a

\footnotetext{
${ }^{22}$ MARTORELL, op. cit., p. 30

${ }^{23}$ SILVA, Luiz Augusto Beck da, op. cit., p. 8.

${ }^{24}$ REYMOND, Claude. Essai sur la nature et les limites de l'acte fiduciare. Montreux : Ganguin et Laubscher, 1948, p. 5.
} 
transferência da propriedade implicava na transmissão da posse, pois, conforme ensina Buzaid $^{25}$, os jurisconsultos romanos encontraram uma forma de manter o devedorfiduciante na posse do bem a título de precário ou de locação, de modo a garantir-lhe o gozo da coisa, sem, contudo, afetar o caráter absoluto da propriedade do fiduciário, cuja faculdade de retomar a coisa a qualquer tempo ou finda a locação continuava tutelada.

Dessa forma, o devedor continuava a usar a coisa e o credor não podia perder a sua propriedade pela usureceptio, que era uma forma anormal de usucapião que conferia certa proteção ao devedor-fiduciante.

Diferindo da forma regular de usucapião, a usureceptio não exigia boa-fé nem justa causa para a sua configuração, mas apenas que o devedor-fiduciante, antigo proprietário que havia dado determinada coisa em garantia real (móvel ou imóvel) ao credor-fiduciário, retomasse a sua posse pelo período ininterrupto de um ano no caso da fiducia cum amico de modo a ser restituído na propriedade. Já na fiducia cum creditore, Martorell ${ }^{26}$ observa que, além da posse da coisa por um ano, o devedorfiduciante devia "haber saldado la deuda a que estaba afecta la obligación fiduciaria."

Já a natureza obrigacional da fidúcia era representada pelo pactum fiduciae, que era uma convenção isenta de formalidade e acessória à mancipatio ou à in iure cessio pelo qual o fiduciário se obrigava a restituir (remancipare) a coisa ao fiduciante quando quitado o pagamento (pecunia soluta). O pactum fiduciae é o cerne da fidúcia, sem ele a operação fiduciária era inexistente. E é a partir do pactum fiduciae que é possível observar a estrutura dualista da fidúcia do tipo romano: a primeira etapa de natureza real constituída pela transferência solene da propriedade pela mancipatio ou pela in iure cessio e a segunda etapa de natureza estritamente obrigacional mediante a celebração do pactum fiduciae, na qual era estabelecida a obrigação do credorfiduciário de remancipare a res.

Diferentemente do penhor, no qual a inexistência ou invalidade da obrigação garantida também anula a garantia real (pignus, no caso), na fidúcia, a transferência da propriedade pela mancipatio ou pela in iure cessio era definitiva independentemente da validade ou existência do débito garantido. A partir dessa análise, é possível inferir que a operação fiduciária, apesar de conectadas por um ponto em comum, o pactum fiduciae, era composta de duas operações autônomas e distintas: uma real e outra obrigacional.

${ }^{25}$ BUZAID, op. cit., p. 11.

${ }^{26}$ MARTORELL, op. cit., p. 35. 
Ressalva-se que, na hipótese de o fiduciante inadimplir a sua obrigação de pagar a dívida no prazo estabelecido, o fiduciário, pleno proprietário da coisa, era autorizado a aliená-la, a fim de, com o fruto da venda, satisfazer o seu crédito sem a concorrência com os demais credores do fiduciante. Caso o preço da coisa sobejasse o montante devido, o fiduciante podia pedir o reembolso da diferença.

\subsubsection{A actio fiduciae}

Com base no pactum fiduciae surgia o dever do fiduciário de restituir a coisa ao fiduciante quando extinto o crédito garantido. Convém observar que a restituição não estava apenas condicionada ao pagamento do débito, mas, também, a todos os demais fatos jurídicos que pudessem ensejar a liberação do devedor, tais como, a novação e a compensação voluntária, por exemplo.

Dado o caráter indivisível da garantia fiduciária, o pagamento parcial não tinha o condão de liberar proporcionalmente a garantia. Esta persistia na sua integralidade até o cumprimento da obrigação pelo devedor e, como visto, caso o fiduciário alienasse a coisa para satisfazer o crédito em aberto, o quantum que excedesse o valor da dívida (superfluum), deveria ser restituído ao devedor.

De uma forma geral, num primeiro momento, o fiduciante não dispunha de qualquer remédio para reaver a propriedade da coisa entregue ao fiduciário quando quitada a dívida (pecunia soluta), no caso da fiducia cum creditore, ou cessada a ameaça ou circunstância alheia futura, na hipótese da fiducia cum amico. Ao fiduciante também não era permitido reaver o bem caso ele tivesse sido alienado a terceiros pelo fiduciário, na medida em que ele não detinha o chamado direito de sequela. Num primeiro momento, a única sanção aplicada ao fiduciário que se recusava a restituir a coisa ou que havia a alienada a terceiros era apenas de ordem moral, inexistindo qualquer outro meio para forçar o fiduciário a cumprir a obrigação assumida no pactum fiduciae ou, pelo menos, indenizar o fiduciante.

Posteriormente, o fiduciante passou a dispor de uma actio (ação) para obter o ressarcimento pela perda da coisa transmitida ao fiduciário: a actio fiduciae directa. Tal instrumento tinha natureza estritamente pessoal e, por tal motivo, o fiduciante não podia obter a anulação de eventual alienação a terceiro, restando apenas pleitear indenização por perdas e danos em face do fiduciário pelo descumprimento do pactum fiduciae (não restituição da coisa). 
Já o fiduciário dispunha de três remédios para cobrar do fiduciante as despesas havidas com a conservação do bem e com as benfeitorias introduzidas: a retenção da coisa, se ela estivesse em seu poder; a compensação; e a actio fiduciae contraria, na hipótese de a retenção da coisa e da compensação não surtirem o efeito pretendido.

\subsubsection{A decadência da fidúcia como garantia real}

A fidúcia do tipo romano revelava-se extremamente vantajosa ao credor-fiduciário, que recebia a plena propriedade da coisa, com todas as faculdades a ela inerentes, que eram limitadas apenas pela obrigação de cunho moral de não fazer uso de tais faculdades em prejuízo do devedor-fiduciante.

Por outro lado, a fidúcia era diametralmente desvantajosa ao devedor-fiduciante, que só podia ser restituído na propriedade da coisa depois de cumprida a sua obrigação de saldar a dívida, e, ainda corria o risco de perder o bem se o credor-fiduciário descumprisse o pactum fiduciae, situação em que não poderia reivindicar a coisa de terceiros, restando apenas pleitear indenização por perdas e danos, já que a ação era de caráter pessoal e somente podia ser ajuizada contra o credor-fiduciário ou seus herdeiros.

Moreira Alves ${ }^{27}$ enumera os seguintes inconvenientes causados pela fidúcia tanto ao devedor-fiduciante quanto ao credor-fiduciário:

a) para o devedor, porque ele tinha que transferir a propriedade da coisa ao credor, não podendo fruí-la enquanto não se extinguisse o débito; além disso, às vezes, o devedor era obrigado a transferir a propriedade de coisa de valor bem superior ao do débito, não podendo, portanto, utilizar-se dela para a obtenção de outros créditos; e, enfim, o devedor, para reaver a coisa, ficava, primitivamente, na dependência exclusiva da vontade do credor, pois não dispunha contra este uma actio (ação) para compeli-lo à restituição da coisa; e, mesmo mais tarde, quando surgiu a actio fiduciae, era ela uma ação pessoal contra o credor, razão por que, se este alienasse a coisa a terceiro, podia obter apenas indenização pelo não cumprimento do pacto de restituição da coisa (pactum fiduciae), e não, a anulação da venda ao terceiro;

${ }^{27}$ ALVES, op. cit., p. 389-390. 
b) para o credor, porque, embora com a transferência da propriedade da coisa ficasse ele perfeitamente garantido, se ela recaísse na posse do devedor, este, ao fim de apenas um ano (mesmo se se tratasse de imóvel), recuperaria a propriedade sobre ela, mediante uma modalidade especial de usucapião denominada usureceptio."

Em razão da rigidez e dos inconvenientes causados pela fidúcia, que implicavam na perda da propriedade pelo fiduciante, que, por sua vez, não dispunha de meios eficazes para recuperá-la caso o fiduciário se recusasse a restituí-la, o direito romano criou novos institutos com o mesmo escopo de garantia com nuances menos drásticas do que a fidúcia, notadamente no que dizia respeito ao desapossamento do bem pelo devedorfiduciante. Dentre as novas modalidades de garantias reais introduzidas no sistema jurídico romano, destacam-se a hipoteca e o penhor.

Mesmo após o surgimento da hipoteca e do penhor, Martore $1^{28}$ assinala que a fiducia cum creditore continuou a ser usada em Roma para garantia de pagamento de débito por conta da sua eficácia, afinal, o credor era investido na propriedade da coisa e dela podia dispor e alienar em caso de inadimplemento do devedor. A única obrigação do credor-fiduciário era devolver a coisa ao devedor-fiduciante assim que a dívida fosse paga, nos termos do pactum fiduciae.

Apesar de a fidúcia ter sido extinta pelo Corpus Iuris Civilis do século VI e, consequentemente, não ter sido contemplada nem no Código Civil francês de 1804, nem no BGB de 1896 e nem no Código Civil brasileiro de 1916, conforme observa Luiz Augusto Beck da Silva ${ }^{29}$, a sua simplicidade e eficácia persistiram no tempo.

Essas breves notas históricas acerca da fidúcia no direito romano demonstram a importância do instituto para a criação e introdução de institutos relevantes no ordenamento jurídico do Brasil, especialmente a alienação fiduciária, claramente inspirada na fiducia cum creditore, e o depósito e o comodato, cuja fonte foi a fiducia cum amico.

\footnotetext{
${ }^{28}$ MARTORELL, op. cit., p. 38.
}

${ }^{29}$ SILVA, op. cit., p. 7. 


\subsection{No direito germânico}

O direito germânico também apresentava instituto jurídico de caráter assecuratório com características semelhantes à fidúcia do tipo romano. Há divergência doutrinária acerca da influência ou não da fidúcia romana na concepção da do tipo germânico. Enquanto alguns autores, dentre eles Martorell ${ }^{30}$ e Otto de Sousa Lima ${ }^{31}$, assinalam que a fidúcia germânica teve sua origem na romana, outros autores, com destaque para Aderbal da Cunha Gonçalves ${ }^{32}$, afirmam que no antigo direito germânico já existia uma figura semelhante, mas com feição própria, o chamado Salmann, posteriormente substituído pela figura do Treuhand.

Para Otto de Sousa Lima ${ }^{33}$ é inegável o fato de o povo germânico ter sido influenciado pelo direito romano, seja pelo desenvolvimento das relações comerciais entre os dois povos, seja pelo fato de o povo germânico ter se colocado como sucessor do Império Romano. Com isso, diversos institutos do direito romano acabaram por ser recebidos e adaptados pelo povo germânico, dentre eles, a fidúcia, que, embora não seja absolutamente idêntica a do tipo romana, com esta guarda traços semelhantes e, na substância, preenche finalidade idêntica: a garantia real do pagamento da dívida.

A principal distinção entre os dois tipos de fidúcia estava na limitação ao poder jurídico conferido ao proprietário. Conforme exposto anteriormente, na fidúcia romana, ao receber a propriedade da coisa do fiduciante com escopo de garantia do pagamento da dívida pela mancipatio ou pela in iure cessio, o fiduciário tornava-se proprietário pleno do bem, com poderes ilimitados do ponto de vista real. A única limitação tinha caráter estritamente obrigacional e era fixada por meio do pactum fiduciae, que era o pacto adjeto à mancipatio e à in iure cessio, pelo qual o fiduciário se obrigava a restituir a coisa ao fiduciante quando verificada a satisfação do débito. Nesse contexto, cabia ao devedor apenas confiar na boa-fé do credor, razão pela qual a fides (confiança) era o elemento marcante da operação fiduciária.

Na hipótese de o fiduciário descumprir a obrigação estabelecida no pactum fiduciae, somente restava ao fiduciante ajuizar uma ação de caráter pessoal em face do fiduciário visando apenas ao recebimento de uma indenização, pois a sua relação com a coisa não mais existia, uma vez que, com a celebração da mancipatio ou da in iure cessio,

\footnotetext{
${ }^{30}$ MARTORELL, op. cit., p. 43.

${ }^{31}$ LIMA, op. cit., p. 122.

${ }^{32}$ GNÇALVES, Aderbal da Cunha, op. cit., p. 225.

${ }^{33}$ LIMA, op. cit., p. 120.
} 
ela passou à esfera de domínio do fiduciário, que, por ser o verdadeiro proprietário do bem, podia ceder a sua propriedade a terceiro adquirente.

Essa desproporcionalidade entre o meio (transmissão da propriedade) e o fim pretendido (garantia de um crédito) inexistia no direito germânico, o qual desenvolveu uma fidúcia com nuances próprias denominada de "penhor de propriedade". Pelo referido instituto, o fiduciante entregava, a título assecuratório de uma obrigação, um fundo ao fiduciário por meio de uma carta venditionis, que, por seu turno, se comprometia a restituir a coisa por meio da emissão de uma contracarta.

A partir dessa operação do direito germânico, é possível identificar as similitudes existentes entre o penhor de propriedade e a fidúcia romana: a transmissão da propriedade com escopo de garantia pela mancipatio ou pela in iure cessio no direito romano e no direito tedesco pela carta venditionis, e a celebração de um pacto adjeto, representando o elemento obrigacional de restituição da coisa no caso de pagamento tempestivo do débito.

Apesar das semelhanças entre os institutos, na fidúcia germânica, a restituição da coisa ao fiduciante era realizada automaticamente assim que satisfeita a sua obrigação, podendo ele, fiduciante, inclusive, reivindicar o bem de quem quer que o detivesse (direito de sequela). Por outro lado, em caso de inadimplemento do fiduciante, o fiduciário era constituído na propriedade plena da coisa, podendo aliená-la a terceiros, a fim de satisfazer o seu crédito.

Nesse sentido, Alfredo Buzaid $^{34}$, com base no magistério de Schupfer, indica que, na fidúcia do tipo germânico, o devedor transferia a propriedade ao credor, celebrando em conjunto um acordo que estabelecia a sua restituição tão logo o devedor, dentro do prazo convencionado, solvesse a dívida. Esse pacto adjeto era anotado na carta de venda, que era o título translativo de propriedade, tornando a venda condicional: uma vez quitado o débito pelo devedor, a venda era resolvida e o credor devia restituir a carta de venda.

No direito moderno, Moreira Alves ${ }^{35}$ observa que foi a partir do estudo de Regelsberger sobre cessão fiduciária elaborado no ano de 1880 que a atenção dos estudiosos se voltou para uma figura denominada negócio fiduciário no direito germânico, cuja base seria a fidúcia romana.

${ }^{34}$ BUZAID, op. cit., p. 12-13.

${ }^{35}$ ALVES, op. cit., p. 25. 
Segundo Moreira Alves ${ }^{36}$, a tese de Regelsberger veio a ser desenvolvida por Goltz, quem identificou a conjugação de dois contratos na formação do negócio fiduciário germânico: um contrato real positivo, pelo qual se dá a transferência da propriedade, e outro chamado contrato obrigatório negativo, no qual é estipulada a obrigação do fiduciário de restituir a coisa ao fiduciante ou retransferi-la a terceiro. Essa teoria foi denominada dualista ${ }^{37}$, pois, assim como a fidúcia do direito romano, dois negócios jurídicos eram celebrados com o objetivo de constituir a garantia de um crédito.

Tal concepção foi combatida pela chamada corrente monista, a qual, representada por Grassetti, entendia que o negócio jurídico se tratava de um negócio unitário e causal, sendo a sua causa a causa fiduciae atípica, porquanto não disciplinada em lei. $^{38}$

Em razão de a fidúcia germânica ter sido consolidada no sistema jurídico tedesco através das figuras do manusfidelis, do Salmann e do Treuhand, para a sua compreensão, revela-se necessária a análise dessas figuras peculiares, que correspondem ao papel desempenhado pelo fiduciário na fidúcia do tipo romano.

\subsubsection{A figura do manusfidelis}

Em razão da complexidade das normas relativas à sucessão e a atos inter-vivos no antigo direito germânico, foi concebida a figura de um intermediário denominado manusfidelis, que era pessoa de confiança do doador quem recebia a propriedade de todo ou de parte do patrimônio a ser doado, para, a seu critério, praticar atos de disposição necessários à salvação da alma do doador. ${ }^{39}$

Essa operação não se restringia às donatio causa mortis, podendo ser utilizada quando o fiduciante ainda estava vivo, ocasião em que as doações eram acompanhadas das cláusulas post mortem ou de reserva de usufruto, que acabavam por extrair do manusfidelis o poder de disposição do patrimônio enquanto o fiduciante estivesse vivo. No entanto, o manusfidelis gozava de amplo poder para executar a vontade

\footnotetext{
${ }^{36}$ ALVES, op. cit., p. 27.

${ }^{37}$ Segundo Moreira Alves, a teoria dualista foi concebida por Goltz, quem, oito anos após a publicação do trabalho de Regelsberger sobre negócio fiduciário, afirmou que o negócio fiduciário, em sua estrutura íntima, resulta da conjugação de contratos: (a) um contrato real positivo, pelo qual se dá a transferência da propriedade; e outro contrato obrigatório negativo, pelo qual nasce a obrigação do fiduciária de restituir a coisa ao fiduciante, após o implemento da condição. ALVES, op. cit., p. 27.

${ }^{38}$ ALVES, op. cit., p. 27-28.

${ }^{39}$ LIMA, op. cit., p. 127.
} 
do fiduciante, inexistindo a necessidade de o fiduciante determinar antecipadamente quem seriam os destinatários dos bens.

Assim como na fiducia cum amico, a confiança era instituto essencial na relação entre o fiduciante e o manusfidelis, na medida em que a propriedade dos bens do fiduciante era transmitida ao manusfidelis, quem, por sua vez, tinha a obrigação de transmiti-los aos beneficiários eventualmente indicados pelo fiduciante ou praticar atos de liberalidade objetivando as doações pro anima.

\subsubsection{A figura do Salmann}

Assim como o manusfidelis, o Salmann também desempenhava a função de intermediário nas operações envolvendo a transmissão de um fundo do alienante ao adquirente, desempenhando a função de fiduciário.

A figura do Salmann foi modificada no decorrer da evolução do direito germânico: $a b$ initio, ele figurava como intermediário do alienante com a responsabilidade de transferir determinado a terceiro e, posteriormente, passou a figurar como intermediário do adquirente, razão pela qual a sua obrigação não mais era transmitir a propriedade para terceiro, mas, sim, adquiri-la para o comprador. A utilização do Salmann visava reforçar a posição do adquirente, pois impedia que bens fossem vendidos por aqueles que não eram seus legítimos proprietários.

Como o Salmann recebia a propriedade em nome do adquirente, ele passava a ser titular de um direito real até que a transmissão ao destinatário determinado fosse concretizada. Todavia, esse direito real era limitado e, conforme ensina Martorell ${ }^{40}$, caso fosse violado, o adquirente e seus herdeiros podiam reivindicar a coisa de terceiros, pois a alienação pelo Salmann era considerada ineficaz. Portanto, assim como na fidúcia do tipo romano, o elemento confiança entre o adquirente e o Salmann também se fazia presente, contudo, esse era o único liame de semelhança entre referidos institutos, porquanto o Salmann não era titular pleno da propriedade.

\subsubsection{A figura do Treuhand}

${ }^{40}$ MARTORELL, op. cit., p. 41-42. 
Segundo Aderbal da Cunha Gonçalves ${ }^{41}$, a figura do Treuhand se assemelhava à figura do fiduciário romano e foi utilizada em diversas situações no direito tedesco, tais como, celebração de esponsais no direito de família, convenção de herdeiros no direito sucessório, e, mormente, no direito patrimonial, com o recebimento da propriedade de bens de um amigo em situações de perigo (como na fiducia cum amico) ou para assegurar um crédito (fiducia cum creditore).

Contudo, as similaridades entre a fidúcia romana e o Treuhand cessam aí, pois, como ensina o aludido autor, não havia a transmissão definitiva da propriedade em tais situações, "senão uma separação da propriedade formal, que legitimava a sua atuação frente à propriedade material, que ficava em poder do fiduciante, ou, então, eram atribuídos poderes ao fiduciário, limitados." Dessa forma, o Treuhand (fiduciário) adquiria a titularidade real limitada sobre determinada coisa a ele transmitida em confiança pelo fiduciante, a qual era condicionada resolutivamente, ensejando a sua restituição automática, com eficácia real erga omnes, ao fiduciante quando ocorrido o pagamento da dívida.

\subsubsection{A distinção entre a fidúcia do tipo romano e a do tipo germânico}

A partir da breve exposição acerca da fidúcia do tipo germânico e com base na doutrina de Moreira Alves ${ }^{42}$ é possível indicar os seguintes traços que distinguem aquela da do tipo romano:

a) no direito germânico, o fiduciário era titular de um direito real limitado à uma condição resolutiva, ao passo que, no direito romano, o fiduciário era proprietário pleno da coisa dada em garantia, podendo dela usar, fruir e dispor;

b) enquanto na fidúcia germânica, o devedor readquiria automaticamente a propriedade da coisa dada em garantia assim que adimplida a sua obrigação de pagar o débito (condição resolutiva), na fidúcia romana, tal fato não se verificava, sendo necessário que o fiduciário e o fiduciante celebrassem nova mancipatio ou in iure cessio, a fim de a propriedade ser restituída ao último;

c) na hipótese de haver abuso de direito por parte do fiduciário, no direito germânico, o fiduciante poderia reaver a coisa de terceiros, dado que a condição resolutiva era dotada de eficácia real erga omnes. Entretanto, isso não era possível no

${ }^{41}$ GONÇALVES, op. cit., p. 223-224.

${ }^{42}$ ALVES, op. cit., p. 31-32. 
direito romano, pois o fiduciário, proprietário pleno da coisa, poderia ceder a sua legítima propriedade a terceiros, restando ao fiduciante pleitear indenização por meio da actio fiduciae directa; e

d) caso o fiduciante inadimplisse a sua obrigação de quitar o débito, o fiduciário na fidúcia do tipo germânico era automaticamente constituído na propriedade plena da coisa, podendo aliená-la a terceiro para fins de satisfação do seu crédito, ao passo que, no direito romano, o fiduciário era titular de direito real ilimitado a partir do momento que recebia o bem do fiduciante por meio da mancipatio e da in iure cessio.

Assim, ao invés de um direito real pleno e absoluto do fiduciário sobre a coisa recebida em garantia, tal qual se verificava no direito romano, na fidúcia germânica, esse direito era limitado à condição resolutiva, que, uma vez alcançada, se operava com eficácia erga omnes contra terceiros que eventualmente haviam adquirido a coisa.

\subsection{No direito anglo-saxão}

$\mathrm{O}$ antigo direito anglo-saxão também apresentou duas figuras semelhantes à fidúcia do tipo romano: o mortgage clássico e o trust. Tais institutos tiveram início na Inglaterra, e, apesar de terem surgido por motivos distintos, guardam entre si a confiança (trust) como caractere comum. Enquanto no mortgage clássico, a propriedade era transferida ao credor a título assecuratório de um débito, que, mediante um pacto adjeto, se obrigava a restituir a coisa ao devedor, no trust, a transferência da propriedade para uma pessoa (trustee) pelo settlor (instituidor) visava ao benefício econômico de terceira pessoa denominada beneficiary ou cestui que trust.

\subsubsection{O mortgage clássico}

No direito inglês medieval, uma das modalidades de aquisição da propriedade era denominada feoffment with livery of seisin. De acordo com Holdsworth ${ }^{43}$, feoffment era uma espécie do gênero doação do direito à plena propriedade sobre a terra (land). Contudo, o feoffment somente era aperfeiçoado com a entrega da seisin, que era a posse legal do feudo. Para transferência da seisin era realizada um ato solene denominado

${ }^{43}$ HOLDSWORTH, W. S. Historical Introduction to the Land Law. Oxford at the Clarendon Press, 1927, p. 112. 
"livery of seisin" pelo qual o feoffor entregava parte ou a integralidade da seisin ao feoffee. $\mathrm{O}$ mencionado autor assinala que a origem dessa rígida regra de entrega da seisin devia-se à importância de dar publicidade ao ato e, talvez, à influência do direito romano e à incapacidade do homem primitivo de conceber a transmissão da propriedade sem uma verdadeira traditio.

Nesse sentido, Otto de Sousa Lima ${ }^{44}$, com base em Franceschelli, indica a semelhança existente entre a estrutura do feoffment e da mancipatio ou da in iure cessio, que eram modos de aquisição de aquisição da propriedade no direito romano.

No que concerne ao mortgage clássico, o fiduciário, originalmente chamado feoffee e, mais tarde, mortgagee, recebia por meio do feoffment with livery of seisin a propriedade de determinada real property (imóvel) do fiduciante feoffor, posteriormente denominado mortgagor a título de garantia do pagamento de uma dívida.

O termo mortgage é composto de duas palavras de origem francesa: "mort", cujo significado é "morte", e "gage", que significa "promessa", portanto, "promessa de morte", que contrastava do "vivum vadium" ou "living pledge" (promessa de vida), pelo qual o devedor, que havia obtido dinheiro emprestado, transferia um imóvel ao seu credor, a fim de que este usasse os frutos da terra até que o débito fosse integralmente quitado de modo que o imóvel jamais "morria" para o devedor.

Já na "mortuum vadium", correspondente ao mortgage, o imóvel permanece na propriedade do credor, sujeito ao cancelamento somente pelo pagamento da dívida na data limite do seu vencimento. Littleton, referido por Samuel W. Eager ${ }^{45}$, explica que o motivo do termo mortgage seria a incerteza acerca do pagamento pelo devedor no prazo convencionado e, se ele não pagasse, a terra, dada em garantia por condição, era tomada dele para sempre, tornando-se, portanto, "morta" perante ao devedor.

Holdsworth $^{46}$ indica a existência de três diferentes métodos de efetivar o mortgage no direito inglês entre os séculos treze e quinze:

a) o devedor devia entregar ao credor determinado valor a título de aluguel, o qual era destinado ao pagamento do débito e, ao mesmo tempo, servia para fornecer interest ao credor de modo a evitar qualquer suspeita sobre eventual prática do pecado da usura;

\footnotetext{
${ }^{44}$ LIMA, op. cit., p. 141.

${ }^{45}$ EAGER, Samuel W. The law of the chattel mortgages and sales and trust receipts with forms. 1941, Buffalo: Law Book Publishers, p. 4.

${ }^{46}$ HOLDSWORTH, op. cit., p. 70-71.
} 
b) o devedor devia entregar a terra ao credor por determinado período de tempo, com a condição que, se o débito não fosse pago ao final do termo, o credor seria consolidado na propriedade do bem a título de pagamento; e

c) o devedor devia entregar a terra ao credor em pagamento, com a condição que, se o débito fosse quitado na data combinada, a terra deveria ser restituída ao devedor. Esse era o método de mortgage mais utilizado naquele período.

Ao receber a propriedade através do feoffment, o mortgagee fiduciário passava a deter o direito pleno, absoluto e ilimitado de propriedade sobre o bem transferido pelo mortgagor fiduciante. Por esse motivo, é possível identificar os seguintes traços comuns entre o mortgage clássico no direito inglês e fiducia cum creditore: a) a transmissão da propriedade por ato solene; b) a celebração de pacto adjeto estabelecendo a obrigação de o credor restituir a propriedade ao devedor originário quando resgatada a dívida; e c) o credor era proprietário pleno da coisa dada em garantia.

Conforme ensina Eduardo Salomão $\mathrm{Neto}^{47}$, na justiça medieval inglesa havia um importante órgão jurisdicional chamado "Chancellor" (Corte de Chancelaria), que era encarregada da análise de questões de justiça natural não abrangidas pelo common law (nem in ius nem at law). Segundo o referido doutrinador, na prática, a posição da Chancelaria equivalia a dos pretores romanos dado que cabia à ela adaptar as rígidas disposições legais aos ditames da equity (equidade), ou seja, de acordo com a sua consciência. Desse modo, tornou-se prática comum as pessoas que sentiam prejudicadas endereçarem petições diretamente à Chancelaria, a fim de este decidisse a questão controvertida com base na equity.

Nesse contexto, era inadmissível do ponto de vista da equity, que o mortgagor fiduciante, por não ter cumprido a prestação no dia fixado perdesse definitivamente a propriedade sobre o bem dado em garantia, cujo valor era maior do que o quantum devido. A partir deste entendimento, foi construída a figura típica do direito anglo-saxão denominada equity of redemption.

Indica Otto de Sousa Lima $^{48}$ que, pela equity of redemption, passou o devedor a dispor de um remédio que o permitia a pagar a dívida mesmo após o seu vencimento dentro de um prazo razoável - no máximo 12 anos - "desde que pagasse, além do capital, todos os juros acumulados e os danos decorrentes da mora." Assim, a equity of

\footnotetext{
${ }^{47}$ SALOMÃO NETO, Eduardo. O trust e o direito brasileiro. São Paulo: Ed. LTR, 1996, p. 14.

${ }^{48}$ LIMA, op. cit., p. 144-145.
} 
redemption passou a ser parte indissolúvel do mortgage, mesmo que no ato constitutivo não se fizesse qualquer referência a ela, era presumida iuris et de iure.

Por outro lado, a equity também se preocupou em atender aos anseios do credor, conferindo a este o direito de propor uma ação visando obrigar o devedor a exercitar o equity of redemption dentro do prazo, sob pena de perda da propriedade. Na hipótese de o devedor não exercitar o equity of redemption no prazo estabelecido, o Tribunal emitia o absolute decree of foreclosure (decreto definitivo de execução da garantia), pelo qual o devedor era privado definitivamente da propriedade, sem a possibilidade de sequer efetuar o pagamento.

Apesar de ter estrutura praticamente idêntica à fiducia cum creditore, com a presença de um elemento real (entrega da propriedade por meio de ato solene) e de um elemento obrigacional (restituição da coisa quando cumprida a obrigação), o processo evolutivo do mortgage clássico no direito inglês acabou por conferi-lo um aspecto peculiar, mais semelhante ao penhor de propriedade do direito germânico do que da fidúcia romana.

\subsubsection{O trust}

A figura do trust do direito anglo-saxão teve como origem o instituto jurídico denominado uses criado no direito medieval inglês. Melhim Namem Chalhub $^{49}$ define uses como uma relação jurídica pela qual o feoffee to use era investido num poder, cujo exercício deveria beneficiar economicamente outra pessoa (cestui que use). Para Eduardo Salomão Neto ${ }^{50}$, o use era a cessão de direitos a um terceiro, a fim de que este administrasse propriedades em favor do cedente ou de outrem por ele indicado. $\mathrm{O}$ termo use foi adotado em razão de a transmissão de um bem de A para B constar a expressão "to the use" (para gozo) de C.

Assim como na fidúcia do direito romano, o common law entendia que o fiduciário (feoffee) era pleno proprietário da coisa entregue pelo fiduciante (feoffor), razão pela qual o use era não era tutelado judicialmente caso o fiduciário (feoffee) descumprisse o seu dever de manter a titularidade da coisa e administrá-la em benefício de terceiro. Por isso, o use era alicerçado na confiança, posto que a sanção por eventual

${ }^{49}$ CHALHUB, Melhim Namem, Negócio fiduciário, 4. ed., rev. e atual. Rio de Janeiro: Renovar, 2009, p. 21-22.

${ }^{50}$ SALOMÃO NETO, op. cit., p. 13. 
inadimplemento do pacto pelo fiduciário era unicamente de ordem moral, da mesma forma que ocorria na fidúcia romana.

Assim como ocorreu no mortgage clássico, a Chancelaria passou a ser chamado a intervir nas relações jurídicas que envolviam o instituto do use em casos que os fiduciários "se mostrassem desidiosos ou mesmo desonestos no cumprimento de suas obrigações" ${ }^{\circ 1}$ em prejuízo ao beneficiário (cestui que use). Ao analisar tais casos, a Chancelaria, com base nos ditames da equity, emitia ordens visando ao devido cumprimento do use pelo fiduciário sob pena de sanções de caráter pessoal.

Segundo Ralph A. Newman ${ }^{52}$, como o rei era o maior de todos os senhores feudais, os uses acabaram por ceifar seus privilégios feudais, sem lhe trazer qualquer benefício, razão pela qual após Henrique VIII, em 1535, após pressionar o Parlamento inglês, foi decretado o "Statute of Uses", que entrou em vigor em $1^{\circ}$ de maio do ano seguinte.

Pelo referido estatuto, os uses foram extintos e as propriedades foram consolidadas na pessoa dos beneficiários, afastando, assim, a injusta alternativa de consolidação da propriedade na pessoa do fiduciário. Contudo, a Chancelaria buscou meios de neutralizar as limitações dos uses sem causar prejuízo ao tesouro real e, entre os séculos XVII e XVIII, adotou o entendimento de que, quando dois ou mais uses fossem constituídos na mesma operação, o estatuto de uses somente seria capaz de extinguir o primeiro deles, ficando convalidados os demais.

Eduardo Salomão Neto exemplifica tal entendimento da Chancelaria da seguinte forma:

Desta forma, se A constituísse um "use" sobre um imóvel em favor de B, passando a esse a titularidade dos direitos reais sobre o bem, e B fizesse o mesmo em relação a um terceiro $\mathrm{C}$, indicando $\mathrm{D}$ como beneficiário da administração do bem, apenas o primeiro dos referidos "uses" (de A para B) seria atacado pelo "Statute of Uses", continuando o outro (de B para C em favor de D) plenamente válido.

Nesse contexto, o estatuto de uses acabou servindo como base para a fundação do moderno sistema de trust, na medida em que o segundo use passou a ser denominado de trust, a fim de diferenciá-lo do primeiro invalidado pelo Statute of Uses.

${ }^{51}$ SALOMÃO NETO, op. cit., p. 15.

${ }^{52}$ NEWMAN, Ralph A. Newman on trusts. 2. ed., Brooklin: The Foundation Press, 1955, p. 30. 
Melhim Namem Chalhub ${ }^{53}$ assevera que a constituição de um trust se dá pela entrega de determinado bem a uma pessoa (trustee) pelo settlor (instituidor), para que esta dele faça uso conforme determinado encargo, "com base na confiança depositada naquele que recebe os bens."

O settlor efetivamente transmitia a propriedade sobre os bens ao trustee, que, por seu turno, tinha a obrigação de administrá-los em benefício de um terceiro (cestui que trust ou beneficiary). Como o trust era pautado na confiança, cabia à Chancelaria coibir eventual abuso do trustee de modo a proteger o beneficiário, porquanto o settlor não mais detinha qualquer interesse sobre a propriedade entregue, permanecendo tão somente a sua vontade refletida no trust.

Além de ser lastreado na confiança, o trust também tem como fundamento básico a dupla propriedade sobre o mesmo bem: a propriedade formal ou nominal (legal property) e a propriedade substancial ou de fruição (equitable property), o que é uma noção incompatível com os sistemas de filiação romana, na qual prevalece o princípio da unicidade do domínio e da incindibilidade do direito subjetivo do proprietário. Assim, no trust, ao trustee caberá a propriedade formal e ao beneficiário a propriedade de fruição.

Conforme salienta Melhim Namem Chalhub ${ }^{54}$, o trust implica na segregação de um patrimônio e no consequente surgimento de um patrimônio de afetação, ao passo em que coíbe que os benefícios econômicos da propriedade formal sejam desfrutados pelo trustee, proprietário formal do bem, e, em contrapartida, assegura uma especial proteção ao direito do beneficiário de usufruir da coisa. Assim, na hipótese de eventual insolvência do trustee, os bens objeto do trust não farão parte da massa concursal, pois já estão vinculados a uma finalidade já definida em contrato.

Diante das peculiaridades do trust, verifica-se que esse instituto, apesar de guardar certa semelhança com a fidúcia, notadamente a presença da confiança no ato da sua celebração, difere dos tipos romano e germânico, "colocando-se sob o tipo fiduciário de legitimação", nas palavras de Otto de Sousa Lima. ${ }^{55}$

${ }^{53}$ CHALHUB, Melhim Namem. Trust - perspectivas do direito contemporâneo na transmissão da propriedade para administração de investimentos e garantia. Rio de Janeiro: Renovar, 2001, p. 19.

${ }_{54}^{54}$ CHALHUB, op. cit., p. 30.

${ }^{55}$ LIMA, op. cit., p. 163. 


\subsubsection{O trust receipt}

Com a evolução das relações negociais, o trust ganhou novos contornos, passando a ser utilizado em diversas situações e atendendo as diferente necessidades. Dentre essas novas espécies de trust, destaca-se o trust receipt, assim definido por Orlando Gomes ${ }^{56}$ :

Provém a alienação fiduciária em garantia, segundo alguns escritores, do trust receipt, instituído para financiamento dos revendedores de bens duráveis, que se vendem pelo sistema de floor planning. O revendedor recebe um adiantamento correspondente a parte do custo do bem, que lhe é entregue em confiança, obrigando-se a resgatar a dívida contraída, tãologo venda a mercadoria. O financiador garante-se, com o trust receipt, em virtude de registro do respectivo documento, através do qual os demais credores do revendedor podem saber que as mercadorias (automóveis, aparelhos de televisão, geladeiras) garantem o financiamento, liberando-as à medida que se forem vendendo. A propriedade das mercadorias é transferida ao financiador até o reembolso, mediante entrega do conhecimento de embarque, ficando o revendedor como depositário."

Naturalmente, o modelo do trust receipt despertou a atenção de outros países, inclusive do Brasil. Nesse sentido, Moreira Alves ${ }^{57}$ assinala que um dos idealizadores da alienação fiduciária em garantia de bens imóveis no direito brasileiro, José Luiz Bulhões Pedreira, ao apresentar a justificativa da introdução de tal modalidade de garantia, afirmou que ela teria sido inspirada no trust receipt do direito estadunidense.

Apesar de ressalvar que o trust receipt e a alienação fiduciária não se confundirem, Orlando Gomes identifica semelhanças entre os institutos do trust receipt e da alienação fiduciária em garantia, asseverando que ambos são fundamentados no fator confiança, "porquanto o alienante permanece na posse do bem e se apresenta, aos olhos de todos, como seu proprietário, que está a usá-lo." 58

\footnotetext{
${ }^{56}$ GOMES, Orlando. Alienação fiduciária em garantia. São Paulo: Ed. Revista dos Tribunais, $3^{a}$ ed., rev. e ampl., 1972, pp. 18/19.

${ }_{57}$ ALVES, op. cit., p. 12-13.

${ }^{58}$ GOMES, loc. cit.
} 
Esse é o mesmo entendimento de Arnoldo Wald, que, reconhecendo a dificuldade de concepção de uma dupla propriedade sobre o mesmo bem no direito brasileiro, salienta que tal fato se verifica de forma análoga - mas não idêntica - na alienação fiduciária em garantia. ${ }^{59}$

\subsubsection{O chattel mortgage}

Moreira Alves ${ }^{60}$ observa que, dentre os institutos do direito norteamericano, talvez aquele que mais se aproxime da alienação fiduciária em garantia no direito brasileiro seja o chattel mortgage, que consiste numa espécie de hipoteca sobre bem móvel (personal property), também denominada de "personal property mortgage."61

Samuel W. Eager enumera algumas definições de chattel mortgage apresentadas por decisões prolatada por Cortes norte-americanas, com destaque para aquela proferida no caso Hermiker Milss Co.: "Uma chattel mortgage é em essência uma transferência de propriedade como garantia sujeita à restituição mediante pagamento do débito ou cumprimento da obrigação.",62

Samuel W. Eager também ensina que a chattel mortgage é uma espécie de venda condicionada (conditional sale), pela qual é feita a transferência da propriedade de uma coisa móvel (personal property) pelo proprietário (owner) para outra pessoa a título de garantia pelo pagamento de um débito ou cumprimento de outra obrigação com o acordo, expresso ou implícito, que, mediante pagamento ou cumprimento, a propriedade deverá ser restituída ao transfereer (transmitente).

Nesse sentido, o aludido autor cita decisão proferida pela Corte de Apelações de Nova York que entendeu que a ideia de chattel mortgage é de entrega da coisa móvel para garantir o débito do fiduciante, que sendo condicional naquele momento, torna-se absoluta, se, no prazo estipulado, a propriedade deixar de ser resgatada. ${ }^{63}$

\footnotetext{
${ }^{59}$ WALD, Arnoldo. Algumas considerações a respeito da utilização do "trust" no direito brasileiro. Revista de Direito Mercantil Industrial, Econômico e Financeiro, Ed. Revista dos Tribunais, n. 99, julhosetembro/1995, p. 110.

${ }^{60}$ ALVES, op. cit., p. 40-41.

${ }^{61}$ EAGER, op. cit., p. 2

${ }^{62}$ EAGER, op. cit., p. 2. "A chattel mortgage is in essence a transfer of title as security subject to the reversion of the title upon payment of the debt or performance of the obligation." In re Hermiker Mills. Co. 39 Fed (2d) 625.

${ }^{63}$ EAGER, op. cit., p. 2. "A mortgage on personal property is defined to be a conditional sale of chattels, by which the legal title thereto is transferred to the mortgagee, to be defeated only by complete performance of the condition, and it suffices, in my opinion, that the parties intended a sale of the chattels as security." In re Ultrop-Huff Co. 9 Fed (2d) 922, citing, Blake v. Corbett, 120 NY 327, 31 St. Rep 31, 24 NE 477.
} 
Portanto, no direito estadunidense, a chattel mortgage caracteriza-se pela venda da propriedade formal (legal property) de um bem móvel como garantia, remanescendo a propriedade de fruição (equitable property) com o mortgagor (devedor hipotecário).

Apesar de não serem institutos idênticos, as estruturas da alienação fiduciária em garantia e do chattel mortgage são extremamente semelhantes. Enquanto na alienação fiduciária há transferência da propriedade fiduciária ao credor sob condição resolutiva (pagamento da dívida pelo devedor) e o desdobramento da posse em direta e indireta, sendo que o devedor permanece na posse direta do bem, na chattel mortgage ocorre processo semelhante, porém dentro das peculiaridades do common law, porquanto o credor recebe a propriedade formal também sob condição resolutiva e o devedor remanesce com a propriedade de fruição, figura semelhante à posse direta no civil law.

Em ambas as situações, se o devedor deixar de pagar o débito, a propriedade é consolidada na pessoa do credor. No entanto, na alienação fiduciária, o credor deve ingressar na posse do bem por meio de processo judicial, ao passo que, na chattel mortgage, a propriedade é consolidada automaticamente na pessoa do credor. 


\section{CAPÍTULO 2 O DECLÍNIO DA HIPOTECA COMO GARANTIA REAL}

\subsection{O surgimento da hipoteca no direito romano}

A partir do estudo das garantias reais no direito romano, é possível aferir a evolução dos institutos que objetivam garantir a proteção do crédito de modo a acomodar tanto o interesse do credor, que pretende ter o seu crédito tutelado, quanto o do devedor, disposto a prestar garantia que não lhe cause maiores inconvenientes.

A fiducia cum creditore, por outro lado, caracterizava-se pelo desequilíbrio entre o meio (transferência da propriedade) e o fim pretendido (garantia do pagamento da dívida), pois, ao receber a propriedade do fiduciante a título de garantia, o fiduciário passava a ter pleno domínio sobre a coisa, podendo dela dispor livremente, sem que ao fiduciante coubesse qualquer instrumento para obrigar o fiduciário a cumprir a sua obrigação de restituir o bem na hipótese de pagamento do débito. O fiduciante apenas dispunha da actio fiduciae directa para pleitear indenização por perdas e danos contra o fiduciário que eventualmente abusasse de seu direito, seja pela recusa em remancipar a coisa, seja pela alienação do bem a terceiros.

Ademais, a celebração da fidúcia era cercada por extrema formalidade: a transferência da propriedade ao fiduciário somente poderia ser realizada pela mancipare ou pela in iure cessio, para, posteriormente, ser firmado o pacto adjeto (pactum fiduciae) pelo qual o fiduciário se obrigava a restituir a coisa ao fiduciante mediante a quitação da dívida. Com o declínio da mancipare e da in iure cessio, a fiducia cum creditore deixou de ser utilizada pelos romanos como modalidade de garantia, desaparecendo por completo na legislação de Justiniano.

O desenvolvimento do comércio em Roma exigia um mecanismo de garantia informal apto a acompanhar o dinamismo das relações negociais e, ao mesmo tempo, capaz de assegurar o crédito, sem onerar demasiadamente o devedor, que até então era desapossado do bem através da fidúcia. Foi nesse contexto histórico que surgiu, a hipoteca no direito romano ${ }^{64}$, cuja denominação deriva do grego hipothéke, que significa "suporte", "pedestal", "garantia".

${ }^{64}$ ALVES, op. cit., p. 386-387. 
Pela hipoteca, o devedor, na maioria das vezes produtor rural, oferecia em garantia da dívida contraída os inuecta et illata (bens móveis, tais como escravos, gado, utensílios, máquinas agrícolas), sem, contudo, ser desapossado desses bens necessários ao desempenho da sua atividade agrícola e consequente pagamento do débito.

\subsection{O surgimento e o declínio da hipoteca no direito brasileiro}

O instituto da hipoteca consolidou-se como uma das principais modalidades de garantia real e foi adotada em diversos países que seguiram o direito romano, dentre eles, o Brasil. Contudo, a adoção da hipoteca pelo direito brasileiro passou por um período de maturação, que culminou no seu nascedouro e na criação do sistema de transmissão de propriedade imobiliária pelo registro do título translativo perante o Registro de Imóveis.

No Brasil imperial, quando ainda eram aplicadas as Ordenações Filipinas, inexistia qualquer interesse do legislador brasileiro concernente à introdução de normas que regulassem a transferência da propriedade imóvel inter vivos e muito menos o direito real de garantia. Por sinal, naquele período, a tradição bastava para transmissão do bem imóvel. Entretanto, esse cenário veio a mudar com o desenvolvimento das relações negociais, notadamente aquelas relacionadas com o comércio de café, pois, para captar recursos para aquisição de terras e insumos, contratação de mão de obra para o trabalho na lavoura, etc., os fazendeiros precisavam garantir o seu pagamento. Assim, o instituto da hipoteca tornou-se mecanismo indispensável para fomentação do crédito.

Em 21 de outubro de 1843, surgiu a Lei Orçamentária, que, apesar de ter como fim a elaboração do orçamento para os exercícios de 1843-1844 e 1844-1845, estabeleceu no seu Artigo 35 o Registro Hipotecário destinado à inscrição de hipotecas, in verbis:

Art. 35 - Fica creado hum Registro geral de hipotecas, nos lugares e pelo modo que o Gôverno estabelecer nos seus Regulamentos.

Em 1846, referido dispositivo legal veio a ser regulamentado pelo Decreto $\mathrm{n}^{\circ} 482$, que, nos seus trinta e três artigos, tratou, dentre outros tópicos, do local de registro da hipoteca, da pessoa responsável em requerer o registro e em executá-lo, dos documentos necessários para registro da hipoteca, dos efeitos do registro. Todavia, o legislador, mais uma vez demonstrando a sua falta de interesse em ajustar a desordenada 
situação fundiária no Brasil, deixou passar a oportunidade de também regular a transmissão da propriedade imobiliária.

Por ser impossível conceber a existência de um sistema de garantia real sem a existência de um registro das transmissões de propriedade, a Lei $n^{\circ}$ 317/1843 e o Decreto $n^{\circ} 482 / 1846$ revelaram-se inócuos ao fim pretendido, qual seja, a fomentação de crédito pelo instituto jurídico da hipoteca. A fim de corrigir tal equívoco, em 1864, foi introduzida no ordenamento jurídico brasileiro a Lei Hipotecária $\mathrm{n}^{\circ} 1.237$, que, cuidou de diversos aspectos atinentes à hipoteca, especialmente a publicidade da hipoteca por meio da transcrição, bem como da criação do Registro Geral.

Posteriormente, em 1890, a Lei Hipotecária foi substituída pelo Decreto $n^{\circ} 169$-A, regulamento pelo Decreto ${ }^{\circ} 370$, que sanaram a ausência de regulação na Lei Hipotecária sobre a necessidade de especialização para os casos de hipoteca legal, mantendo os seus demais termos.

Em 1916, o Código Civil incorporou a hipoteca como direito real (artigo 674, IX) e a regulou em Capítulo próprio - Capítulo XI (artigo 809 e seguintes) -, bem como alterou o nome do Registro Geral previsto na Lei Hipotecária para Registro de Imóveis. Além disso, em 1919, através do Decreto $\mathrm{n}^{\circ}$ 3.725, foi incluído o inciso VII ao artigo 810 do Código Civil de 1916, que cuidava da hipoteca de navios, o que representou uma inovação ao sistema hipotecário até então vigente.

Cinquenta anos depois da entrada em vigor do Código Civil de 1916, foi promulgado o Decreto-Lei $\mathrm{n}^{\circ} 70 / 66$ que permite o credor escolher entre a execução hipotecária na forma dos artigos 298 e 301 do Código de Processo Civil ou dos artigos 31 a 38 do referido Decreto-Lei. Caso o credor opte pela segunda alternativa, ele deverá formalizar ao agente fiduciário a solicitação da execução da dívida (art. $31^{65}$ ), que, por sua vez, deverá promover a notificação do devedor, por intermédio do Cartório de Títulos e Documentos, para purgar a mora no prazo de vinte dias $\left(\S 1^{\circ}\right.$ do art. $\left.31^{66}\right)$.

Caso o devedor deixe de purgar a mora no prazo indicado, o agente fiduciário estará autorizado a publicar editais e a efetuar o primeiro leilão extrajudicial do

\footnotetext{
${ }^{65}$ BRASIL. Decreto-Lei n ${ }^{\text {7 }} 70 / 66$. Art. 31. Vencida e não paga a dívida hipotecária, no todo ou em parte, o credor que houver preferido executá-la de acordo com este decreto-lei formalizará ao agente fiduciário a solicitação de execução da dívida, instruindo-a com os seguintes documentos:

${ }^{66}$ BRASIL, Decreto-Lei $n^{\circ} 70 / 66$. Art. 31, $\S 1^{\circ}$. Recebida a solicitação da execução da dívida, o agente fiduciário, nos dez dias subseqüentes, promoverá a notificação do devedor, por intermédio de Cartório de Títulos e Documentos, concedendo-lhe o prazo de vinte dias para a purgação da mora.
} 
imóvel hipotecado em quinze dias (art. $32^{67}$ ). Se, no primeiro leilão, o maior lance obtido for inferior ao saldo devedor, será realizado o segundo leilão nos quinze dias subsequentes, no qual será aceito o maior lance apurado, ainda que inferior à soma do saldo devedor, acrescido dos valores previstos no artigo $33^{68}$, mais as do anúncio e contratação da praça, nos termos dos $\S \S 1^{\circ}$ e $2^{\circ}$ do artigo $32^{69}$.

Efetivada a alienação do imóvel na forma do artigo 32, será emitida a carta de arrematação, assinada pelo leiloeiro, pelo credor, pelo agente fiduciário, e por cinco pessoas físicas idôneas, absolutamente capazes, como testemunhas. Tal documento servirá como título translativo de propriedade para fins de registro perante o Registro de Imóveis, conforme preceitua o artigo $37^{70}$. Registrada a carta de arrematação, o adquirente poderá requerer ao juízo competente a sua imissão na posse do imóvel, que lhe será concedida liminarmente, sem prejuízo do prosseguimento do feito, pelo rito ordinário, caso o devedor apresente contestação ( $§ 2^{\circ}$ do artigo $\left.37^{71}\right)$.

Cinco anos após a introdução do Decreto-Lei n ${ }^{\circ} 70 / 66$, passou a vigorar a Lei $\mathrm{n}^{\mathrm{o}} 5.741$ de $1^{\text {o }}$ de dezembro de 1971, que, a fim de estimular o desenvolvimento imobiliário no país, estabeleceu a execução hipotecária especial vinculada ao chamado Sistema Financeiro da Habitação (Art. $1^{\circ 72}$ ). Os Artigos $3^{\circ}$ e $4^{\circ}$ da

\footnotetext{
${ }^{67}$ BRASIL, Decreto-Lei no 70/66. Art. 32. Não acudindo o devedor à purgação do débito, o agente fiduciário estará de pleno direito autorizado a publicar editais e a efetuar no decurso dos 15 (quinze) dias imediatos, o primeiro público leilão do imóvel hipotecado.

${ }^{68}$ BRASIL, Decreto-Lei no 70/66. Art. 33. Compreende-se no montante do débito hipotecado, para os efeitos do artigo 32, a qualquer momento de sua execução, as demais obrigações contratuais vencidas, especialmente em relação à fazenda pública, federal, estadual ou municipal, e a prêmios de seguro, que serão pagos com preferência sôbre o credor hipotecário.

${ }^{69}$ BRASIL, Decreto-Lei $n^{\circ}$ 70/66. Art. 32. $\S 1^{\circ}$ Se, no primeiro público leilão, o maior lance obtido fôr inferior ao saldo devedor no momento, acrescido das despesas constantes do artigo 33, mais as do anúncio e contratação da praça, será realizado o segundo público leilão, nos 15 (quinze) dias seguintes, no qual será aceito o maior lance apurado, ainda que inferior à soma das aludidas quantias.

$\S 2^{\circ}$ Se o maior lance do segundo público leilão fôr inferior àquela soma, serão pagas inicialmente as despesas componentes da mesma soma, e a diferença entregue ao credor, que poderá cobrar do devedor, por via executiva, o valor remanescente de seu crédito, sem nenhum direito de retenção ou indenização sôbre o imóvel alienado.

${ }^{70}$ BRASIL, Decreto-Lei n ${ }^{\circ}$ 70/66. Art. 37. Uma vez efetivada a alienação do imóvel, de acôrdo com o artigo 32, será emitida a respectiva carta de arrematação, assinada pelo leiloeiro, pelo credor, pelo agente fiduciário, e por cinco pessoas físicas idôneas, absolutamente capazes, como testemunhas, documento que servirá como titulo para a transcrição no Registro Geral de Imóveis.

${ }^{71}$ BRASIL, Decreto-Lei ${ }^{\circ}$ 70/66. Art. 37. § $2^{\circ}$ Uma vez transcrita no Registro Geral de Imóveis a carta de arrematação, poderá o adquirente requerer ao Juízo competente imissão de posse no imóvel, que lhe será concedida liminarmente, após decorridas as 48 horas mencionadas no parágrafo terceiro dêste artigo, sem prejuízo de se prosseguir no feito, em rito ordinário, para o debate das alegações que o devedor porventura aduzir em contestação.

${ }^{72}$ BRASIL, Lei $n^{\circ} 5.741 / 71$. Art. $1^{\circ}$. Para a cobrança de crédito hipotecário vinculado ao Sistema Financeiro da Habitação criado pela Lei no 4.380, de 21 de agosto de 1964, é lícito ao credor promover a execução de que tratam os artigos 31 e 32 do Decreto-lei no 70, de 21 de novembro de 1966, ou ajuizar a ação executiva na forma da presente lei.
} 
aludida lei $^{73}$ estabelecem que o devedor, devidamente citado, terá o prazo de vinte e quatro para pagar a dívida acrescida de encargos, juros, custas judiciais e honorários advocatícios, sob pena de penhora do imóvel hipotecado, com a nomeação do exequente como depositário do bem.

Na hipótese de o imóvel ainda estiver ocupado pelo executado, o $\S$ $2^{\circ}$ do artigo $4^{\circ}$ prevê a sua desocupação no prazo de trinta dias pelo executado e a sua entrega ao exequente. $\mathrm{O}$ artigo $5^{\circ}$ autoriza a oposição de embargos pelo executado, os quais serão recebidos com efeito suspensivo, desde que demonstre a ocorrência de uma das hipóteses previstas nos seus incisos I e II $^{74}$. Rejeitados os embargos, o artigo $6^{\circ}$ estabelece que o juiz determinará a venda do imóvel hipotecado em praça pública "por preço não inferior do saldo devedor." ${ }^{, 75}$ Inexistindo licitante, o juiz adjudicará ao exequente o imóvel hipotecado, "ficando exonerado o executado da obrigação de pagar o restante da dívida", nos termos do artigo $7^{0^{76}}$.

Como se vê, o liame comum entre o Decreto-Lei $n^{\circ} 70 / 66$ e a Lei ${ }^{\circ}$ 5.741/71 é a preocupação do legislador em assegurar a celeridade e a eficácia dos procedimentos da execução hipotecária, visando promover a injeção de recursos no sistema imobiliário pelas instituições financeiras. Afinal, o investidor pretende liquidar o seu crédito o mais rápido possível na hipótese de inadimplemento do devedor. Todavia, o fim pretendido não foi alcançado por força de questionamentos acerca do cerceamento de defesa e de outras eventuais nulidades.

Conforme será demonstrado em capítulo próprio, a constitucionalidade do leilão extrajudicial foi e até hoje é alvo de grande controvérsia, tendo, inclusive, sido considerado inconstitucional pelo extinto $1^{\circ}$ Tribunal de Alçada Cível do Estado de São Paulo ${ }^{77}$, nos termos da sua Súmula nº 39:

${ }^{73}$ BRASIL, Lei $\mathrm{n}^{\circ} 5.741 / 71$. Art . $3^{\circ} \mathrm{O}$ devedor será citado para pagar o valor do crédito reclamado ou depositá-lo em juízo no prazo de vinte e quatro horas, sob pena de lhe ser penhorado o imóvel hipotecado. Art . $4^{\circ}$ Se o executado não pagar a dívida indicada no inciso II do art. $2^{\circ}$, acrescida das custas e honorários de advogado ou não depositar o saldo devedor, efetuar-se-á penhora do imóvel hipotecado, sendo nomeado depositário o exeqüente ou quem êste indicar.

${ }^{74}$ BRASIL, Lei $\mathrm{n}^{\circ} 5.741 / 71$. Art. $5^{\circ}$. I - que depositou por inteiro a importância reclamada na inicial;

II - que resgatou a dívida, oferecendo desde logo a prova da quitação.

${ }^{75}$ BRASIL, Lei $n^{\circ} 5.741 / 71$. Art . $6^{\circ}$ Rejeitados os embargos referidos no caput do artigo anterior, o juiz ordenará a venda do imóvel hipotecado em praça pública por preço não inferior do saldo devedor expedindose edital pelo prazo de 10 (dez) dias.

${ }^{76}$ BRASIL, Lei $\mathrm{n}^{\circ} 5.741 / 71$. Art . $7^{\circ}$ Não havendo licitante na praça pública, o Juiz adjudicará, dentro de quarenta e oito horas, ao exeqüente o imóvel hipotecado, ficando exonerado o executado da obrigação de pagar o restante da dívida.

77 BRASIL. Extinto $1^{\circ}$ Tribunal de Alçada Cível do Estado de São Paulo, Embargos Infringentes $n^{\circ}$ 1.304.841-4/01, Rel. Des. Ademir Benedito, j. 30.08.2005, com a seguinte ementa: "Contrato - Mútuo - 
São inconstitucionais os artigos 30, parte final, e 31 a 38 do Decreto-Lei $\mathrm{n}^{\mathrm{o}} 70$ de 21.11.1966.

Some-se a lentidão dos atos constitutivos da hipoteca, o assoberbamento do Poder Judiciário às discussões que orbitam em torno do Decreto-Lei $\mathrm{n}^{\mathrm{o}}$ 70/66 e da Lei $\mathrm{n}^{\circ}$ 5.741/71 para facilmente constatar o total descompasso entre os mecanismos de recuperação de crédito pela garantia hipotecária e a atual conjectura econômica, conforme assinala Viegas de Lima:

Dentre os fatores que seguramente influenciaram com esta situação caótica, temos a interferência do Estado nas relações de mercado - como ainda ocorre no sistema Financeiro de Habitação - e a quase total falta de dinâmica nos mecanismo de recuperação do crédito, principalmente em casos de inadimplemento do devedor. Tudo isto em total descompasso com a moderna conceituação de economia de mercado ou de escala. ${ }^{78}$

Nesse mesmo sentido, Marcelo Terra ${ }^{79}$ assevera que a alienação fiduciária atenua as dificuldades enfrentadas na execução dos tradicionais instrumentos de garantia, na medida em que oferece maior rigor e eficiência na segurança do crédito, "principalmente devido ao crescente abalo, pelo Poder Judiciário, ao prestígio da hipoteca como fomentador da garantia de crédito."

Desse modo, para atender às necessidades do mercado imobiliário, especialmente a concessão de crédito a juros menores, a economia atual exige rapidez e eficiência na liberação e recuperação do crédito quando houver inadimplemento. Para tanto, é preciso criar mecanismos que autorizem o investidor a constituir e executar a garantia a um custo reduzido. Somente assim é possível tornar o mercado imobiliário atraente para quem pretende investir seu capital. E, como visto, a hipoteca deixou de atender a esses preceitos basilares da economia moderna, o que abriu caminho para a criação de uma nova garantia real que permitisse ao credor a rápida recuperação do seu crédito, sem onerar demasiadamente o devedor.

Foi dentro desse contexto jurídico-econômico que o legislador brasileiro, inspirado pela bem sucedida experiência da alienação fiduciária de bens móveis,

Sistema Financeiro da Habitação - Inconstitucionalidade da execução extrajudicial com base no DL 70/66 Incidência da Súmula 39 do extinto $1^{\circ}$ TAC - Recurso desprovido - Decisão mantida."

${ }^{78}$ LIMA, Frederico Henrique Viegas de Lima. Da alienação fiduciária em garantia de coisa imóvel. $2^{\mathrm{a}}$ ed. (ano 2003), $4^{\mathrm{a}}$ tiragem (ano 2006). Curitiba: Juruá Editora, 2006, p. 31.

${ }^{79}$ TERRA, Marcelo, Alienação fiduciária em garantia, Porto Alegre: SAFE, 1998, p. 21. 
criou a alienação fiduciária de coisa imóvel, conforme observa Patrícia André de Camargo Ferraz $^{80}$ :

Com a fragilização da hipoteca, enquanto instrumento de garantia para financiamentos voltados para a aquisição da casa própria, o país demandava a criação de um direito de garantia que nos colocasse ao lado dos países desenvolvidos, em termos de observância e fiel cumprimento dos contratos firmados. Já não era mais possível que os contratos celebrados para aquisição de moradia tivessem elevados índices de inadimplência, pois tal situação gerava um risco negocial extremamente alto para os prestamistas, o que os afastava do mercado. A consequência disso, logo se viu, foi a falta de crédito para a população, de modo que mesmo aqueles que honravam suas obrigações passaram a padecer com a escassez de financiamentos imobiliários. Os bons pagadores passaram a pagar, de uma forma de outra, pelos maus pagadores...

Em razão disso, a onda de ajustes para proporcionar o desenvolvimento dos sistema imobiliário se estendeu até o Direito Civil, quando se criou a alienação fiduciária de bens imóveis.

\subsection{A propriedade fiduciária como opção de garantia real}

Se analisado sob uma perspectiva diferente, é possível identificar que, mesmo numa sociedade industrial, o crédito não deve ser apenas destinado às indústrias, mas, também, aos consumidores, a fim de estimular um ciclo virtuoso: os consumidores, com capital, consomem mais produtos industrializados, gerando, como consequência, o aumento de produção das indústrias, que, por sua vez, necessitam de mais funcionários, dando origem a novos empregos.

Como visto, no século passado, as garantias reais originadas no direito romano - hipoteca, penhor e anticrese - revelaram-se inaptas para atender aos objetivos da sociedade industrial, seja pela morosidade e alto custo da sua execução, seja "pela superposição a elas de privilégios em favor de certas pessoas, especialmente do Estado." ${ }^{81}$ Dessa forma, buscou-se alternativas para atender ao dinamismo dos negócios de forma a permitir um ambiente profícuo à expansão do crédito.

${ }^{80}$ FERRAZ, Patrícia André de Camargo. As novas oportunidades para o advogado, decorrentes do crescimento imobiliário. Revista do Advogado, São Paulo, n. 90, p. 120-127, Mar. 2007, p. 121.

${ }^{81}$ ALVES, op. cit., p. 3. 
Num primeiro momento, uma das soluções encontradas foi a utilização dos chamados contratos indiretos. Orlando Gomes, citando Cariota Ferrara, assevera que, por meio de tais contratos, "as partes se valem de caminho transversal para alcançar resultado inatingível com o emprego das figuras conhecidas no ordenamento positivo." 82

Um dos exemplos de contrato indireto largamente usado no passado com o escopo de garantia é o pacto de reserva de domínio, instituto pelo qual o vendedor transfere a posse ao comprador, mantendo para si a propriedade do bem a título de garantia.

Outra modalidade de garantia empregada naquele período foi a retrovenda com finalidade de garantia, pela qual o vendedor de coisa imóvel podia reservar-se o direito de recobrá-la no prazo decadencial de três anos, nos termos do artigo 1.141 do Código Civil de 1916. Esse prazo decadencial foi mantido pelo Código Civil de 2002 (artigos 505 a 508).

Entretanto, as aludidas modalidades de garantia - pacto de reserva de domínio e retrovenda com finalidade de garantia - não foram capazes de atender plenamente aos anseios dos credores, que muitas vezes tinham que enfrentar os percalços que surgiam contra o uso daquelas figuras. Atento à necessidade de criação de novas garantias reais capazes de propiciar segurança ao credor, rápida execução da garantia, sem, por outro lado, onerar excessivamente o devedor, em 1965, foi introduzido no ordenamento jurídico brasileiro o instituto da alienação fiduciária em garantia por meio da Lei ${ }^{\circ} 4.728 / 65$, cuja origem remonta aos primórdios do direito romano.

Cumpre salientar que a alienação fiduciária configura-se como sendo contrato (meio) para constituição da propriedade fiduciária (fim). Sobre essa distinção, Moreira Alves ${ }^{83}$ ensina:

Para bem compreender-se a alienação fiduciária em garantia, é mister que se distingam duas figuras, a que a Lei $\mathrm{n}^{\mathrm{o}} 4.728$ e, posteriormente, $\mathrm{o}$ Decreto-lei no 911 aludem:

a) a alienação fiduciária em garantia; e

b) a propriedade fiduciária.

A alienação fiduciária em garantia é, tão-somente, o contrato que serve de título à constituição da propriedade fiduciária, que - esta, sim - é a

${ }^{82}$ GOMES, op. cit., p. $25-26$

${ }^{83}$ ALVES, op. cit., p. $45-46$ 
garantia real criada, em nosso direito, pelo art. 66 da Lei $n^{\circ} 4.728$, modificado, posteriormente, pelo Decreto-lei no 911.

A Lei $n^{\circ} 4.728 / 65$ foi adotada imediatamente pelas instituições financeiras, que, respaldadas pela nova modalidade de garantia real - propriedade fiduciária -, responsável por eliminar um dos principais entraves para a execução das garantias reais: a permanência do devedor na posse e na propriedade da coisa gravada, passaram a conceder crédito direto aos consumidores. Naquele momento, a tutela ao crédito parecia garantir satisfatoriamente o credor, que, ao ter transferida para a sua titularidade a propriedade resolúvel da coisa móvel, passava a ter uma garantia real mais eficiente que as demais, pela qual, caso a dívida não fosse paga, poderia vender o bem e pagar-se.

Porém, em razão da imprecisão do texto do Artigo 66 da Lei ${ }^{\circ}$ 7.428/65, as primeiras dúvidas acerca do remédio jurídico hábil a permitir a execução da garantia resultante da alienação fiduciária começaram a surgir. $\mathrm{O} \S \S 2^{\circ}$ e $8^{\circ}$ do mencionado dispositivo legal assim dispunha:

$\S 2^{\circ}$. O instrumento de alienação fiduciária transfere o domínio da coisa alienada, independentemente de sua tradição, continuando o devedor a possuí-la em nome do adquirente, segundo as condições do contrato, e com as responsabilidades do depositário.

$\S 8^{\circ}$. O proprietário fiduciário, ou aquele que comprar a coisa, poderá reivindica-la de devedor ou de terceiros, no caso do $\S 5^{\circ}$ deste artigo.

Parte da doutrina e da jurisprudência entendia ser pertinente o ajuizamento de ação de reintegração de posse pelo credor, pois este seria possuidor indireto da coisa, ao passo que o devedor inadimplente, ao recusar-se a devolver o bem, passaria a figurar como esbulhador da posse do credor. O credor, portanto, estaria autorizado a pleitear a sua reintegração na posse, liminarmente, quando atendido aos pressupostos legais - "posse com menos de ano e dia". Neste sentido, destaca-se a sentença proferida pelo juiz de Direito da $14^{\mathrm{a}}$ Vara Cível da Comarca de São Paulo, Dr. Aderito Pereira da Silva:

Tenho para mim que a ação adequada à espécie dos autos é a reintegratória de posse. 
Muito embora tenha o proprietário fiduciário o domínio da coisa, e como é curial a posse indireta, o devedor fiduciário tem a posse direta, pois tem de fato alguns poderes inerentes do domínio ou propriedade, consoante estatui o art. 485 do Código Civil.

$[\ldots]$

Tendo o devedor a posse da coisa que fiduciariamente transferiu o domínio ao credor, pratica esbulho e fica injustamente com ela se deixar de pagar as prestações como combinado. ${ }^{84}$

Também havia o entendimento de que o meio judicial para que o credor ficasse com a posse da coisa seria a imissão na posse, sob a justificativa de que o credor não poderia ser reintegrado na posse, pois jamais a deteve. Nesse sentido, destaca-se o magistério de Luiz Corrêa Fragoso citado no artigo da lavra de Carlos Virgilio Lasalvia publicado no jornal “O Estado de São Paulo" em 8 de dezembro de 1968. ${ }^{85}$

Por fim, uma terceira corrente defendia a tese de que a ação de depósito seria o instrumento judicial competente para o credor retomar a coisa cuja posse era injustamente detida pelo devedor inadimplente. Nesse sentido, Alfredo Buzaid observa: $\mathrm{Na}$ alienação fiduciária em garantia, a circunstância de o devedor deixar de pagar a dívida, no vencimento, não basta para caracterizar turbação ou esbulho. Qualquer destas manifestações surge, se houver recusa de restituir o bem alienado fiduciariamente. Ora, a relação jurídica que o artigo 66, § $2^{\circ}$, da Lei $n^{\circ} 4.728$, institui, em tal caso, não é possessória, mas de depósito, porque o fiduciante possui a coisa em nome do fiduciário. Assim, portanto, a ação para haver a coisa não é possessória, mas de depósito. ${ }^{86}$

Todavia, diversos julgados, seguindo a opinião do Dr. Aderito Pereira da Silva, afastaram a incidência da ação de depósito sob o argumento de que os requisitos para configuração do contrato de depósito não estariam presentes na alienação

\footnotetext{
${ }^{84}$ BRASIL. 14 a Vara Cível da Comarca de São Paulo, Juiz de Direito Dr. Aderito Pereira da Silva, sentença publicada no Diário Oficial do Estado de São Paulo em 01.05.1969, p. 32. Disponível em: < http://www.imprensaoficial.com.br/PortalIO/DO/BuscaDO2001Documento_11_4.aspx?link=/1969/judiciario $/ \mathrm{maio} / 01 /$ pag_0032_EFBBAPFSRECTReBSU06IEM7LNCN.pdf\&pagina=32\&data=01/05/1969\&caderno=J udici\%C3\%A1rio\&paginaordenacao=100032>. Acesso em 08 out 2012.

${ }^{85}$ LASALVIA, Carlos Virgilio. Do depósito na alienação fiduciária. "O Estado de São Paulo”, São Paulo, pág. 58, publicado em 8 dez. 1968. Disponível em: http://acervo.estadao.com.br/pagina/\#!/19681208-28733nac-0058-999-58-not/busca/aliena\%C3\%A7\%C3\%A3o+fiduci\%C3\%A1ria. Acesso em 08 out 2012.

${ }^{86}$ BUZAID, op. cit., p. 57-58
} 
fiduciária em garantia. ${ }^{87}$ Além disso, a constitucionalidade da prisão civil do depositário infiel na alienação fiduciária em garantia também era objeto de questionamento, na medida em que o legislador ordinário não poderia equipará-lo ao verdadeiro depositário dado os consectários do seu inadimplemento - prisão civil.

Diante dessa celeuma, o uso da alienação fiduciária como mecanismo fomentador de crédito ficou seriamente ameaçado, pois o fim pretendido pela Lei ${ }^{\circ} 4.728 / 65$ - tutela eficiente do crédito - não era mais assegurado.

Nesse cenário e atendendo ao anseio das entidades financeiras, foi promulgado o Decreto-Lei $n^{\circ} 911 / 69$ que veio a modificar e a regulamentar a Lei $\mathrm{n}^{\mathrm{o}}$ 4.728/65 tanto no campo material, com alguns ajustes referentes à terminologia, quanto no campo processual, seja com a criação da ação de busca e apreensão de rito sumaríssimo e defesa limitada como meio adequado para o credor reaver a coisa dada em garantia (artigo $3^{\mathrm{o} 8}$ ), seja com a admissão da ação de depósito como meio processual adequado na hipótese de o bem alienado fiduciariamente não estiver na posse do devedor, conforme $\operatorname{artigo} 4^{\mathrm{o}^{89}}$.

Com isso, estava assegurada a eficácia da garantia em alienação fiduciária e, como consequência, o incremento do crédito direto ao consumidor para aquisição de bens de consumo duráveis.

As alterações feitas pelo Decreto-Lei $n^{\circ}$ 911/69 foram, posteriormente, revogadas pelo artigo 55 da Lei $\mathrm{n}^{\circ}$ 10.931/2004, que introduziu o artigo 66-B, a fim de regular a alienação fiduciária no âmbito do mercado financeiro e de capitais, de créditos fiscais e previdenciários, para coisa fungível, cessão fiduciária de direitos sobre coisas móveis e de títulos de crédito. Confira-se:

Art. 66-B. O contrato de alienação fiduciária celebrado no âmbito do mercado financeiro e de capitais, bem como em garantia de créditos fiscais e previdenciários, deverá conter, além dos requisitos definidos na Lei $\mathrm{n}^{\mathrm{o}}$ 10.406, de 10 de janeiro de 2002 - Código Civil, a taxa de juros, a

87 Neste sentido, a sentença prolatada pelo Dr. Aderito Pereira da Silva acima transcrita, citando os ensinamentos de Washington de Barros Monteiro, Carvalho Santos e Caio Mário Pereira da Silva, enumera as seguintes características do contrato de depósito: “a) entrega da coisa pelo depositante ao depositário; b) a natureza móvel da coisa depositada; c) a entregada para o fim de ser guardada; d) a restituição no ensejo aprazado; e) a temporariedade e gratuidade do depósito."

${ }^{88}$ BRASIL. Decreto-Lei $n^{\circ}$ 911/69. Art. 3o. O Proprietário Fiduciário ou credor, poderá requerer contra o devedor ou terceiro a busca e apreensão do bem alienado fiduciariamente, a qual será concedida liminarmente, desde que comprovada a mora ou o inadimplemento do devedor.

${ }^{89}$ BRASIL. Decreto-Lei no 911/69. Art. $4^{\circ}$ Se o bem alienado fiduciariamente não for encontrado ou não se achar na posse do devedor, o credor poderá requerer a conversão do pedido de busca e apreensão, nos mesmos autos, em ação de depósito, na forma prevista no Capítulo II, do Título I, do Livro IV, do Código de Processo Civil. 
cláusula penal, o índice de atualização monetária, se houver, e as demais comissões e encargos.

$\S 1^{0}$ Se a coisa objeto de propriedade fiduciária não se identifica por números, marcas e sinais no contrato de alienação fiduciária, cabe ao proprietário fiduciário o ônus da prova, contra terceiros, da identificação dos bens do seu domínio que se encontram em poder do devedor.

$\S 2^{\circ} \mathrm{O}$ devedor que alienar, ou der em garantia a terceiros, coisa que já alienara fiduciariamente em garantia, ficará sujeito à pena prevista no art. 171, § 2 , I, do Código Penal.

$\S 3^{\circ}$ É admitida a alienação fiduciária de coisa fungível e a cessão fiduciária de direitos sobre coisas móveis, bem como de títulos de crédito, hipóteses em que, salvo disposição em contrário, a posse direta e indireta do bem objeto da propriedade fiduciária ou do título representativo do direito ou do crédito é atribuída ao credor, que, em caso de inadimplemento ou mora da obrigação garantida, poderá vender a terceiros o bem objeto da propriedade fiduciária independente de leilão, hasta pública ou qualquer outra medida judicial ou extrajudicial, devendo aplicar o preço da venda no pagamento do seu crédito e das despesas decorrentes da realização da garantia, entregando ao devedor o saldo, se houver, acompanhado do demonstrativo da operação realizada.

$\S 4^{\underline{0}}$ No tocante à cessão fiduciária de direitos sobre coisas móveis ou sobre títulos de crédito aplica-se, também, o disposto nos arts. 18 a 20 da Lei $\mathrm{n}^{-}$9.514, de 20 de novembro de 1997.

$\S 5^{\circ}$ Aplicam-se à alienação fiduciária e à cessão fiduciária de que trata esta Lei os arts. 1.421, 1.425, 1.426, 1.435 e 1.436 da Lei no 10.406 , de 10 de janeiro de 2002.

$\S 6^{0}$ Não se aplica à alienação fiduciária e à cessão fiduciária de que trata esta Lei o disposto no art. 644 da Lei $\mathrm{n}^{\mathrm{o}}$ 10.406, de 10 de janeiro de 2002.

O Código Civil de 2002, por meio dos artigos 1.361 a 1.368-A, inovou ao regular a figura da propriedade fiduciária de coisas móveis infungíveis, sem interferir diretamente na alienação fiduciária de bens imóveis (Lei $n^{\circ}$ 9.514/97) ou na alienação de coisas móveis fungíveis no âmbito do mercado financeiro e de capitais, agora regulada pelo referido artigo 66-B. 
Joel Dias Figueira $\mathrm{Jr}^{90}$. ensina que apenas os aspectos processuais do Decreto-Lei no 911/69 ainda permanecem em vigor, sendo que as suas normas de direito material foram tacitamente revogadas, pois a lei posterior revoga a anterior quando ambas tratarem do mesmo tema:

Por outro lado, a alienação fiduciária em garantia, regulada pelo DecretoLei n. 911, de $1^{\circ}-10-1969$ (“Altera a redação do art. 66 da Lei n. 4.728, de 14-7-1965, estabelece normas de processo sobe alienação fiduciária e dá outras providências"), considera-se revogada em tudo aquilo que concerne ao direito material e se encontra doravante regulado por este Código. Em outros termos, desde o advento do CC de 2002 (arts. 1.361 e s.), o Decreto n. 911/69 está derrogado, restando-lhe a aplicação exclusiva em sede processual (arts. $3^{\circ}, 4^{\circ}$ e $5^{\circ}$ ). Nesse sentido, não deixa qualquer dúvida a regra insculpida no art. 2.043 do novo Código.

Nada obstante, além da ação de busca e apreensão ou de execução, o proprietário fiduciário poderá também fazer uso de ação reivindicatória e ação de reintegração de posse.

Após a consolidação da propriedade fiduciária no sistema jurídico brasileiro como garantia real de coisa móvel por força do Decreto-Lei n 911/69, parte da doutrina passou a questionar a possibilidade de estender sua aplicação e seus efeitos em operações financeiras envolvendo a aquisição de bens imóveis.

Neste sentido, Carlos Alberto Dabus Maluf ${ }^{91}$ destaca trecho do artigo de autoria de Caio Mário da Silva Pereira intitulado "A nova tipologia contratual no direito civil brasileiro", pelo qual Caio Mário afirma ter incluído o contrato de fidúcia (art. $672^{92}$ ) no Projeto de Código de Obrigações, "procurando introduzir em nosso direito o trust dos sistemas do common law." O artigo 673 do Projeto de Código de Obrigações também previa a possibilidade da fidúcia recair sobre bens imóveis. Neste caso, mencionado dispositivo exigia que o contrato de fidúcia fosse escrito e registrado no competente Registro de Imóveis.

\footnotetext{
${ }^{90}$ FIGUEIRA JR., Joel Dias. Código Civil comentado. Coordenador até a $5^{\mathrm{a}}$ ed. Ricardo Fiuza $-6^{\mathrm{a}}$ ed., rev. e atual. - coordenação de Regina Beatriz Tavares da Silva. São Paulo: Saraiva, 2008, pp. 1450/1451.

${ }^{91}$ MALUF, Carlos Alberto Dabus, Limitações ao Direito de Propriedade, 3. ed., rev. e atual., São Paulo: Ed. Revista dos Tribunais, 2011, p. 191.

${ }^{92} \mathrm{O}$ texto do artigo 672 definia a fidúcia nos seguintes termos: "Pelo contrato de fidúcia, uma das partes, recebendo de outra bens móveis ou imóveis, assume o encargo de administrá-los em proveito do instituidor ou de terceiro, tendo, porém, a livre disposição dos mesmos, sem prejuízo do direito do benficiário."
} 
Essa corrente doutrinária que entendia ser possível a alienação fiduciária de bens imóveis independentemente de previsão legal era fundamentada no magistério de eminentes juristas, dentre eles, Washington de Barros Monteiro e Carlos Alberto Dabus Maluf ${ }^{93}$, que afirmam que outros direitos reais podem ser criados pelo legislador e também pelas próprias partes, desde que, nessa última hipótese, o acordo não contrarie princípios de ordem pública. Referidos autores destacam que outros doutrinadores também defendem esse ponto de vista, pois inexiste texto legal que proíba, explícita ou implicitamente, a criação ou a modificação de direitos reais.

Curiosamente, já na década de 60, o Decreto no 60.501/1967 que regulava a Previdência Social estabelecia, dentre outras garantias, a alienação fiduciária de bens imóveis no seu artigo 186, § 2 " “d”, in verbis:

O $\S 2^{\circ}$ do artigo 186 do Regulamento Geral da Previdência Social, aprovado pelo Decreto $\mathrm{n}^{\circ}$ 60.501, de 14 de março de 1967, passa a vigorar com a seguinte redação:

$\S 2^{\circ}$ Entende-se como garantia, para os efeitos deste artigo e do parágrafo único do artigo 185 , desde que o respectivo valor seja comprovadamente superior a $140 \%$ (cento e quarenta por cento) do total dos débitos da empresa para com a previdência social:

[...]

d) a alienação fiduciária em garantia de bens imóveis.

Contudo, o entendimento de que a alienação fiduciária em garantia previsto no Decreto-Lei no 911/69 poderia ser estendido aos bens imóveis foi rechaçado pela doutrina dominante com base no princípio da taxatividade ou do numerus clausus, que determina que somente é possível criar, alterar ou extinguir direitos e garantias reais através de lei. Neste sentido, Miguel Maria de Serpa Lopes ${ }^{94}$, com apoio em Lafayette e Eduardo Espínola, assinala:

A questão do numerus clausus diz respeito à possibilidade de poderem surgir outras categorias de direitos reais que não os estabelecidos em lei, ou ainda, se os direitos reais podem resultar de uma convenção entre as partes. A propriedade é o centro do sistema dos direitos reais. É o mais

${ }^{93}$ MONTEIRO, Washington de Barros; MALUF, Carlos Alberto Dabus, Curso de Direito Civil, v. 3: direito das coisas, 39. ed., São Paulo, Saraiva, 2009, p. 12.

${ }^{94}$ LOPES, Miguel Maria de Serpa, Curso de direito civil: direito das coisas: princípios gerais, posse, domínio e propriedade imóvel, volume VI, 5. ed., rev. e atual., Rio de Janeiro: Freitas Bastos, 2001, p. 3438. 
amplo dos direitos reais e todos os demais direitos dessa espécie gravitam em torno do de propriedade. São os denominados direitos reais limitados. O problema do numerus clausus é inerente aos direitos reais limitados: se como tais só podem ser considerados os constantes do elenco legal ou se se torna possível conhecê-los quando, a despeito do silêncio da lei, determinado instituto se apresenta com todos os seus característicos, incluída a hipótese de uma convenção que os constitua.

$[\ldots]$

O conteúdo dos direitos reais não pode ser objeto de livre pactuação, e sim corresponder exatamente ao quadro traçado pela lei, em relação a cada um deles. Deste modo, a idéia de numerus clausus nos Direitos Reais representa mais um marco de separação entre os Direitos Reais e os das Obrigações, por isso que, enquanto os primeiros têm por pressuposto a especificidade, as segundas são, em geral, sensíveis à autonomia da vontade, permitindo uma criação permanente e incessante de novas figuras de contrato.

San Tiago Dantas também entende que as partes não podem criar novos direitos reais, "porque sendo certo que os direitos reais prevalecem erga omnes, seria inadmissível que duas, três ou mais pessoas pudesse, pelo acordo de suas vontades, criar deveres jurídicos para toda a sociedade." ${ }^{95}$ Renomado autor, no entanto, ressalva a possibilidade de a lei criar um novo direito real, o qual revogará, em parte, o preceito do artigo 1.225 do Código Civil ${ }^{96}$, correspondente ao artigo 674 do Código Civil de 1916.

${ }^{95}$ DANTAS, Francisco Clementino San Tiago, Programa de direito civil III: direito das coisas, Rev. do texto e anotações de José Gomes de Bezerra Câmara. Atualização de Laerson Mauro. Rio de Janeiro: Ed. Rio, 1979, p. 18-19.

${ }^{96}$ BRASIL. Código Civil, Art. 1.225. São direitos reais:

I - a propriedade;

II - a superfície;

III - as servidões;

IV - o usufruto;

V - o uso;

VI - a habitação;

VII - o direito do promitente comprador do imóvel;

VIII - o penhor;

IX - a hipoteca;

$X$ - a anticrese.

XI - a concessão de uso especial para fins de moradia;

XII - a concessão de direito real de uso. 
Ao diferenciar os direitos reais dos obrigacionais, Sílvio de Salvo Venosa $^{97}$ também observa que os direitos reais inserem-se em numerus clausus, sendo somente considerados direitos reais aqueles previstos em lei.

Pedro Cecilio de Oliveira Neto ${ }^{98}$ destaca a posição de Arnold Wald expressa no artigo intitulado "Novos instrumentos para o direito imobiliário: Fundos, alienação fiduciária e leasing" (RT 434/251), pelo qual referido civilista defendia a transposição e adequação das regras da alienação fiduciária de bens móveis para o mercado imobiliário, transparecendo claramente a necessidade de ser observado o princípio da taxatividade para criação de nova modalidade de garantia real. Naquela ocasião, Arnold Wald propunha a extensão da alienação fiduciária em garantia prevista no Decreto-Lei $\mathrm{n}^{\circ}$ 911/69 aos bens imóveis mediante nova redação ao referido decreto-lei, observadas as peculiaridades dos bens móveis e imóveis, a fim de combater as falhas na cobrança de créditos devido ao extinto Banco Nacional de Habitação ("BNH”).

Não obstante a posição majoritária da doutrina acerca da impossibilidade de constituição de direitos ou ônus reais além daqueles instituídos em leis, parte da doutrina aduz que o princípio da taxatividade dos direitos reais não é inelástico como bem aponta Renan Miguel Saad ${ }^{99}$ que, com apoio em Rubén S. Stiglitz, assevera que os direitos reais "comportam em seu bojo a expressão da autonomia da vontade, desde que não se viole a ordem pública."

Ao que parece, foi esse entendimento do Superior Tribunal de Justiça que, em acórdão anterior à promulgação da Lei $\mathrm{n}^{\circ}$ 9.514/97, decidiu ser possível a celebração de negócio fiduciário tendo como garantia um bem imóvel. Confira-se:

Civil. Negócio fiduciário. Transferência de propriedade de imóvel em garantia de dívida. Pedido de declaração de existência do pacto. Efeito natural de retorno ao estado anterior. Com anulação da escritura. Prescrição. Incidência da norma do art. 177 e não do art. 178, par. 9, v, b, CC. Inexistência de ação anulatória e nem mesmo de simulação. Recurso desacolhido.

I - O negócio fiduciário, embora sem regramento determinado no direito positivo, se insere dentro da liberação de contratar própria do direito

\footnotetext{
${ }^{97}$ VENOSA, Sívio de Salvo, Direito Civil: direitos reais, vol. 5, 7. ed., São Paulo: Atlas, 2007, p. 8.

${ }^{98}$ OLIVEIRA NETO, Pedro Cecilio, Alienação fiduciária em garantia. 1. ed., São Paulo: Livraria e Editora Universitária de Direito Ltda., 1975, p. 40-41.

${ }^{99}$ SAAD, Renan Miguel, A alienação fiduciária sobre bens imóveis, Rio de Janeiro: Renovar, 2001, p. 134-/135.
} 
privado e se caracteriza pela entrega fictícia de um bem, geralmente em garantia, com a condição de ser devolvido posteriormente.

II - Reconhecida a validade do negócio fiduciário, o retorno ao estado anterior é mero efeito da sua declaração de existência, pelo que o bem dado em garantia de débito deve retornar, normalmente, à propriedade do devedor.

III - Inocorre, assim, qualquer pretensão desconstitutiva de contrato, mas sim declarativa de validade, o que afastaria a prescrição definida no art. 178, par. 9, v, b do Código Civil. E nem mesmo se trata de simulação, porque no negócio simulado há um distanciamento entre a vontade real e a vontade manifestada, inexistente no negócio fiduciário." 100

A controvérsia sobre a possibilidade de se constituir ou não a propriedade fiduciária sobre coisa imóvel somente foi sanada com o advento da Lei $\mathrm{n}^{\mathrm{o}}$ 9.514/97, cujo artigo 22 define a alienação fiduciária de bem imóvel nos seguintes termos:

Art. 22. A alienação fiduciária regulada por esta Lei é o negócio jurídico pelo qual o devedor, ou fiduciante, com o escopo de garantia, contrata a transferência ao credor, ou fiduciário, da propriedade resolúvel de coisa imóvel.

André Cordelli Alves ${ }^{101}$ assevera que a introdução da alienação fiduciária de bens imóveis ao nosso ordenamento representou notável evolução no campo das garantias reais, na medida em que, pelo aludido contrato, a propriedade imobiliária é transferida ao credor-fiduciário. Tal fato representa uma vantagem da alienação fiduciária em relação à hipoteca, pois a garantia recai sobre coisa própria enquanto, na hipoteca, a garantia recai sobre coisa alheia (direito real limitado).

Para Melhim Namem Chalhub ${ }^{102}$, além de propiciar campo fértil para o desenvolvimento social, com o combate à escassez de moradia, a Lei $n^{\circ}$ 9.514/97 permitiu o desenvolvimento da chamada desintermediação financeira, que constitui na operação financeira pela qual as empresas financeiras transformam seus direitos creditórios

\footnotetext{
${ }^{100}$ BRASIL. Superior Tribunal de Justiça. Recurso Especial $n^{\circ}$ 57.991-SP, Rel. Min. Sálvio de Figueiredo Teixeira, publicado no DJ. De 29.09.1997.

${ }^{101}$ ALVES, André Cordelli, Alienação fiduciária em garantia de bens imóveis, Revista de Direito Bancário e do Mercado de Capitais, vol. 56, p. 171, Abr/2012, p. 10-11.

${ }^{102}$ CHALHUB, op. cit., p. 2.
} 
em valores mobiliários, a fim de captar recursos no mercado de capitais, "num processo que se convencionou denominar securitização."

Referido autor enumera as três principais inovações introduzidas pela Lei $n^{\circ}$ 9.514/97: a) a criação de um novo título de crédito, lastreado em crédito imobiliário; b) a previsão de funcionamento de companhias destinadas à aquisição e à securitização de créditos imobiliários, mediante a emissão e circulação dos idealizados CRI - Certificados de Recebíveis Imobiliários; e c) a regulamentação da alienação fiduciária em garantia de bens imóveis. ${ }^{103}$

Assim, após quinze anos da vigência da Lei nº 9.514/97, é possível afirmar que o instituto da alienação fiduciária em garantia surgiu como um importante instrumento de fomentação do crédito no setor imobiliário, propiciando ao investidor uma forma segura e eficaz de recuperar o seu investimento, na hipótese de inadimplemento do devedor, além de instituir um novo e atrativo título de crédito - Certificado de Recebível Imobiliário - lastreado na segurança da propriedade imobiliária e com a negociabilidade dos valores mobiliários.

Além disso, a alienação fiduciária também representa uma vantagem ao devedor-fiduciante, que pode utilizar-se da propriedade fiduciária em garantia de outro negócio jurídico, pelo qual obtém um crédito.

${ }^{103}$ CHALHUB, op. cit., p. 2. 


\section{CAPÍTULO 3 O PERFIL DOGMÁTICO DA ALIENAÇÃO FIDUCIÁRIA DE BEM IMÓVEL}

\subsection{A estrutura da alienação fiduciária de bens imóveis}

A Lei $n^{\circ}$ 9.514/97 alberga duas figuras jurídicas distintas, porém intimamente interligadas: (i) a alienação fiduciária em garantia; e (ii) a propriedade fiduciária. A distinção entre esses institutos é imprescindível para a correta interpretação da alienação fiduciária.

Como acentua Moreira Alves ${ }^{104}$, a redação da Lei $n^{\circ} 4.728 / 65$ e, posteriormente, do Decreto-Lei no 911/69 não apresentou de forma clara a distinção entre alienação fiduciária e propriedade fiduciária, dando margem para que autores interpretassem a alienação fiduciária como uma nova forma de garantia real, tal qual o penhor, a hipoteca e a anticrese.

Ainda, segundo Moreira Alves, a alienação fiduciária em garantia é apenas o contrato que serve de título para constituição da propriedade fiduciária, esta, sim, garantia real. Isso também ocorre com as demais modalidades de garantia real previstas no nosso ordenamento. Por exemplo, para constituição da hipoteca, necessário se faz a celebração de um contrato de hipoteca (título), o qual, após ser registrado no competente Cartório de Registro de Imóveis, constituirá a hipoteca, que é a garantia real propriamente dita. O mero contrato de hipoteca não tem o condão de criar a garantia real, fato que somente se concretiza mediante o seu registro no Registro de Imóveis.

Esse desdobramento em dois momentos distintos para constituição da garantia real encontra respaldo nos artigos 1.227 e 1.245 do Código Civil, os quais, respectivamente, estabelecem a necessidade da celebração de um contrato, de um título, destinado à aquisição, constituição ou transferência de um determinado direito ou ônus real, e o seu correspondente registro.

Atento à imperfeição da redação da Lei $n^{\circ} 4.728 / 65$ e do DecretoLei ${ }^{\circ}$ 911/69, o legislador da Lei $n^{\circ} 9.514 / 97$ procurou diferenciar as figuras da alienação fiduciária em garantia e da propriedade fiduciária de forma a não permitir qualquer equívoco quanto à sua interpretação.

${ }^{104}$ ALVES, op. cit., p. 45. 
Assim, o artigo 22 da Lei $n^{\circ}$ 9.514/97 define a alienação fiduciária de coisa imóvel como sendo "o negócio jurídico pelo qual o devedor, ou fiduciante, com o escopo de garantia, contrata a transferência ao credor, ou fiduciário, da propriedade resolúvel de coisa imóvel." Em outras palavras, a alienação fiduciária é o título causal para constituição da garantia real.

Por outro lado, o artigo 23 da aludida Lei declara que a propriedade fiduciária de coisa imóvel se constitui "mediante registro, no competente Registro de Imóveis, do contrato que lhe serve de título." É essa a nova garantia real introduzida pela Lei ${ }^{\circ}$ 9.514/97 em nosso direito real.

O presente estudo organiza-se a partir dessa distinção entre os referidos institutos jurídicos, focando, primeiramente, na análise da alienação fiduciária imobiliária propriamente dita e, depois, na propriedade fiduciária.

\subsection{A definição de alienação fiduciária de bem imóvel}

Conforme exposto no item acima, o artigo 22 da Lei $\mathrm{n}^{\circ}$ 9.514/97 define a alienação fiduciária como o negócio jurídico pelo qual o devedor, ou fiduciante, com escopo de garantia, contrata a transferência ao credor, ou fiduciário, da propriedade resolúvel de coisa imóvel.

Por meio do contrato de alienação fiduciária, o devedor-fiduciante contrata a transmissão ao credor-fiduciário a propriedade resolúvel de coisa imóvel sob seu domínio, a fim de garantir determinada obrigação, normalmente o pagamento do financiamento do próprio imóvel objeto dado em garantia. O contrato de alienação fiduciária não tem cunho obrigacional, na medida em que inexiste vontade de obrigar-se, mas apenas de constituir um direito real de garantia, no caso, a propriedade fiduciária.

Por tal motivo, Moreira Alves ${ }^{105}$ entende que a alienação fiduciária em garantia não se situa no campo do direito das obrigações, mas, sim, no plano do direito das coisas, porquanto o contrato não gera obrigações para as partes.

Orlando Gomes ${ }^{106}$, por sua vez, assevera que o negócio translativo de propriedade se dá no campo do direito das obrigações. A seu ver, as partes acordam em constituir uma relação jurídica obrigacional: enquanto o vendedor se obriga a transferir a propriedade de determinada coisa, o comprador se obriga a pagar o preço. Como o

${ }^{105}$ ALVES, op. cit., p. 56-57.

${ }^{106}$ GOMES, op. cit. p. 36. 
vendedor obriga-se tão somente a transferir, a transmissão da propriedade somente se concretiza por meio do registro do título que lhe deu causa.

Independentemente da discussão acerca de qual plano se situa a alienação fiduciária - se no plano dos direitos reais ou obrigacionais - fato é que a lei do Sistema Financeiro Imobiliário ("SFI") também apresenta outras características da alienação fiduciária imobiliária, que serão abordadas com maior profundidade no decorrer deste trabalho. De qualquer forma, neste momento, vale a menção a tais atributos, mesmo que de forma superficial.

O primeiro deles diz respeito à necessidade da prática de um ato registro do contrato de alienação fiduciária - para constituição da propriedade fiduciária sobre o bem imóvel, esta, sim, uma garantia real. Apenas pelo registro do título perante o competente Registro Imóveis é que se perfaz a garantia. Caso isso não ocorra, a alienação fiduciária não passará de mero contrato sem cunho qualquer obrigatório como ensinamento de Moreira Alves acima exposto.

O artigo 22 da lei do SFI também apresenta outro aspecto relevante: o devedor-fiduciante poderá transferir ao credor-fiduciário a propriedade resolúvel de imóvel pertencente a terceiro. Assim como nas outras modalidades de garantia real, o devedor poderá alienar ao credor um bem de sua propriedade ou de terceiro garantidor. A lei também não obriga que o bem imóvel seja o mesmo porventura adquirido com o financiamento obtido pelo devedor-fiduciante, podendo ser qualquer outro bem imóvel de propriedade do devedor-fiduciante.

Outro ponto que merece destaque refere-se ao $\S 1^{\circ}$ do artigo $22 \mathrm{da}$ Lei $n^{\circ} 9.514 / 97$ que permite a celebração do contrato de alienação fiduciária por pessoa física ou jurídica, não sendo privativa das entidades que operam no SFI. Apesar da expressa autorização legal, Melhim Namem Chalhub ${ }^{107}$ observa que "a aplicação mais frequente da alienação fiduciária de bens imóveis ocorra no mercado das incorporações imobiliárias."

\subsection{O negócio fiduciário e institutos afins}

Parafraseando Orlando Gomes ${ }^{108}$, para determinar a natureza jurídica da alienação fiduciária, primeiramente, é necessário limpar o terreno, afastando

${ }^{107}$ CHALHUB, op. cit., p. 229.

${ }^{108}$ GOMES, op. cit., p. 34. 
tergiversações que possam obstar a sua correta compreensão. Para tanto, é de rigor a distinção do negócio fiduciário, gênero do qual a alienação fiduciária é espécie, como será examinado a seguir, de outros institutos afins, dentre eles, o negócio simulado, o negócio indireto, a venda com reserva de domínio e o compromisso de compra e venda.

\subsubsection{A alienação fiduciária e o negócio fiduciário}

Conforme exposto no Capítulo 1, o negócio fiduciário surgiu no direito romano pelos institutos da fiducia cum amico e da fiducia cum creditore. Em ambas as modalidades de fidúcia, o elemento confiança era parte intrínseca do negócio: o fiduciante entregava determinado bem ao fiduciário para fins de administração (fiducia cum amico) ou de garantia (fiducia cum creditore), confiando que este último restituiria a propriedade da coisa quando cessado eventual ameaça ou quitada a dívida.

Ao analisar os negócios fiduciários no direito romano, Hélio do Valle Pereira ${ }^{109}$ assinala haver um aparente descompasso entre o ato realizado e o objetivo perseguido, "tudo sublinhado pela crença que o devedor (fiduciante) defere ao credor (fiduciário) e aliado à transferência patrimonial com compromisso de restituição."

Cunha Gonçalves explica que, no negócio fiduciário, o fiduciante transmite a propriedade de uma coisa ou de um crédito ao fiduciário, de modo definitivo e ilimitado, assumido este último a posição de dono, no gozo de todas as faculdades inerentes à propriedade perante o fiduciante e a terceiros. Ao fiduciante resta confiar que o fiduciário não desvirtuará a finalidade de sua titularidade, restituindo a coisa quando cumpridas as condições, inclusive e principalmente o pagamento da dívida. ${ }^{110}$

Álvaro Villaça Azevedo ${ }^{111}$ busca em Barea as características do negócio fiduciário, asseverando que a confiança é elemento essencial e decisivo na formação do aludido negócio jurídico, tanto na sua celebração quanto no aspecto de garantia única do cumprimento da obrigação pelo obrigado.

Para Mariano Navarro Martorel1 ${ }^{112}$ os negócios fiduciários podem ser divididos em duas categorias: "puros" e "impuros". Nos negócios fiduciários puros, a titularidade da coisa é transmitida ao fiduciário para satisfazer um interesse do fiduciante.

\footnotetext{
${ }^{109}$ PEREIRA, Hélio do Valle, A nova alienação fiduciária em garantia - aspectos processuais, 2. ed., rev., atual., Conceito Editoral, 2008, p. 27.

${ }^{110}$ GONÇALVES, op. cit., p. 212.

111 AZEVEDO, Álvaro Villaça, Contratos inominados ou atípicos e negócio fiduciário, 3. ed., Belém, CEJUP, 1988, p. 127.

${ }^{112}$ MARTORELL, op. cit., p. 121.
} 
Esse é o caso da fiducia cum creditore pela qual a propriedade é transmitida ao fiduciário com escopo de administração até cessar determinada situação. Já nos negócios fiduciários impuros, Martorell salienta que o objetivo da transmissão da propriedade é a satisfação do interesse tanto do fiduciante - obtenção de crédito, por exemplo - quanto do fiduciário garantia do pagamento da dívida.

Apesar da classificação acima, Martorell salienta que ambas as categorias de negócio fiduciário têm em comum a confiança depositada pelo fiduciante na pessoa do fiduciário de que este cumprirá a sua obrigação pessoal de restituir a propriedade ao fiduciante. E é a partir do elemento confiança que referido autor distingue o negócios fiduciário da alienação fiduciária: enquanto naquele o fiduciante confia que o fiduciário cumprirá a sua obrigação de restituir a propriedade da coisa a ele entregue para administração ou a título de garantia, nesta a relevância do elemento confiança é reduzida ou até menos inexistente na medida em que a legislação preenche tal lacuna. ${ }^{113}$

Entretanto, Álvaro Villaça Azevedo observa que o conceito de negócio fiduciário desenvolvido por Martorell estaria mais completo "se nele constasse a obrigação de restituir ou de transferir a terceiros o bem fiduciado, por parte do fiduciário, logo após realizado o fim negocial proposto." 114 Assim, o culto doutrinador conceitua o negócio fiduciário como sendo

o vínculo jurídico de natureza real, que se estabelece entre o fiduciante (tradens) e o fiduciário (accipiens), pelo qual o primeiro, que confia no segundo, transmite a este um direito ou um bem jurídico, cumpridas as formalidades da mancipatio ou da in iure cessio, seja para garantir o pagamento de uma dívida ou para obter o favor da administração ou guarda de um patrimônio, tudo para que faça certo uso desse objeto fiduciário, dê a ele certo destino, e o restitua ao final de um prazo (advento do termo) ou ao verificar-se uma condição (implemento da condição), sob pena de, descumprida essa obrigação, indenizar os prejuízos causados. ${ }^{115}$

Marcelo Terra ${ }^{116}$ observa que o negócio fiduciário se caracteriza pela presença do risco oriundo da confiança depositada pelo fiduciante na pessoa do

\footnotetext{
${ }^{113}$ MARTORELL, op. cit., p. 126, 127.

${ }^{114}$ AZEVEDO, Álvaro Villaça, Prisão civil por dívida, 2. ed., rev., atual. e ampl., São Paulo: Ed. Revista dos Tribunais, 2000, p. 94.

${ }^{115}$ VILLAÇA. op. cit., p. 94-95.

${ }^{116}$ TERRA, op. cit., p. 19.
} 
fiduciário e, ainda, pelo fato de as partes escolherem um meio (alienação) que excede aos fins por elas objetivados (garantia).

A partir do exame da estrutura do negócio fiduciário é possível verificar que este se forma a partir de dois contratos distintos: um translativo de propriedade com eficácia erga omnes (natureza real) mediante o qual fiduciante transmite a propriedade da coisa ao fiduciante; e outro de natureza pessoal com eficácia inter partes, pelo qual o fiduciário se compromete a devolver a propriedade do bem tão logo satisfeitas as condições pactuadas.

A fidúcia (confiança) que o fiduciante (aquele que acredita) deposita no fiduciário (aquele que é acreditado) de que este restituirá o bem alienado assim que observada a condição convencionada é o cerne do negócio fiduciário. Concretizada a operação, nada resta ao fiduciante a não ser acreditar que o fiduciário cumprirá a sua obrigação. Se isto não ocorrer, restará ao fiduciante exigir em juízo o cumprimento da avença ou pleitear indenização por perdas e danos, porquanto não mais possui direito real.

Apesar de não estar positivado no direito pátrio, o negócio fiduciário é plenamente aceito, conforme decidiu o Superior Tribunal de Justiça por ocasião do julgamento do recurso especial $n^{\circ} 57.991$, cuja ementa foi transcrita anteriormente.

No tocante à alienação fiduciária, nela o elemento confiança é inexistente, pois, cumprida a obrigação do fiduciante, a propriedade retorna à sua titularidade automaticamente por força da lei.

Alfredo Buzaid $^{117}$, com apoio nas definições de negócio fiduciário traçadas por Andreas Von Tuhr e em Grassetti, conclui que a alienação fiduciária é distinta do negócio fiduciário, porquanto aquela é fruto de uma construção doutrinária, destinado a oferecer maior segurança às operações de crédito. Por isso, o fiduciário na alienação fiduciária adquire o domínio da coisa dada em garantia até a integral satisfação da dívida.

Com base nas lições de Dernburg, Alfredo Buzaid ${ }^{118}$ também assinala que, diferentemente do que ocorre negócio fiduciário, no qual o fiduciário é revestido ao mesmo tempo de dupla qualidade - proprietário e mandatário -, na alienação fiduciária o fiduciário é tão somente proprietário do bem, com poderes conferidos por lei para aliená-lo na hipótese de inadimplemento do fiduciante.

${ }^{117}$ BUZAID, op. cit., p. 32-34.

${ }^{118}$ BUZAID, loc. cit. 
Verifica-se, portanto, que a confiança existente no negócio fiduciário é mitigada a partir da sua inserção no ordenamento jurídico. Neste sentido, Orlando Gomes ${ }^{119}$ ensina:

Mas, se a própria lei, ao gizar a figura da alienação fiduciária em garantia, a introduz no esquema da propriedade resolúvel, elimina o riso que demanda confiança, uma vez que, se o fiduciário não honrar o compromisso de restituí-la, pode o fiduciante reivindicá-la, porque se tornou, de novo proprietário da coisa com o implemento da condição resolutória. A sua segurança de reavê-la não está na correção moral do fiduciário, mas na disposição legal que determina a reversão, ao fiduciante, da propriedade do bem que alienou em garantia.

E é exatamente isso o que ocorre na alienação fiduciária prevista na Lei $\mathrm{n}^{\circ}$ 9.514/97: o seu artigo 25 estabelece que a propriedade fiduciária do imóvel se resolve automaticamente com o pagamento da dívida e seus encargos. Inexiste, portanto, qualquer traço do elemento confiança na alienação fiduciária de bens imóveis, já que, na hipótese de o fiduciário não cumprir a sua obrigação de restituir a coisa, o fiduciante, poderá reivindicá-la em juízo com base na aludida disposição legal, porque se tornou novamente pleno proprietário da coisa por força do adimplemento da sua obrigação.

Por outro lado, Paulo Restiffe Neto e Paulo Sérgio Restiffe afirmam que o fator confiança subsiste na alienação fiduciária, "mas tão-somente no sentido da boafé normal, inerente aos negócios em geral, já que existe regulamentação legal sobre o assunto a traçar os limites de atuação e de responsabilidade das partes contratantes."120

Apesar da ausência da fidúcia na alienação fiduciária prevista na lei do SFI, é possível afirmar que mencionado instituto é uma espécie do gênero negócio fiduciário, conforme asseveram Alfredo Buzaid $^{121}$ e Melhim Chalhub ${ }^{122}$, basicamente por dois motivos: (i) porque o fiduciário deve agir com lealdade quando verificado o implemento da condição resolutiva, devolvendo a coisa ao fiduciante; e (ii) porque a transmissão da propriedade se dá em dois momentos distintos: primeiro, a transferência do domínio ao fiduciário a título transitório e com escopo de garantir determinada obrigação

\footnotetext{
${ }^{119}$ GOMES, op. cit., p. 40.

${ }^{120}$ RESTIFFE NETO, op. cit., p. 331.

${ }^{121}$ BUZAID, op. cit., pp. 2, 3.

${ }^{122}$ CHALHUB, op. cit., pp. 132- 133.
} 
assumida pelo fiduciante; depois, a restituição do bem ao fiduciante quando adimplida a obrigação por ele assumida.

\subsubsection{O negócio fiduciário e o negócio simulado}

Orlando Gomes ${ }^{123}$ afirma que, tão logo a fidúcia ressurgiu no direito moderno com traços que não existiam no direito romano, juristas detiveram sua atenção a distinção do negócio fiduciário do negócio simulado. A semelhança entre os dois institutos era tamanha, que a doutrina inicialmente se inclinou para considerar simulados os negócios fiduciários.

De acordo com renomado autor, na transferência da propriedade, seja para administração seja para garantia, a doutrina via traços do instituto da simulação, na medida em que, a seu ver, o contrato translativo ocultava o negócio verdadeiro, qual seja, a constituição de um vínculo de mandato ou de um direito real pignoratício. Por meio do negócio fiduciário, prossegue Orlando Gomes, as partes alcançavam fim para o qual servia de falsa transmissão de propriedade. Assim, no entendimento dos juristas daquela época, o contrato translativo era, na realidade, simulado, por haver, pretensamente, uma divergência entre a vontade real (mandato ou constituição de garantia real) e a vontade declarada (transmissão do domínio).

Otto de Sousa Lima ${ }^{124}$ também destaca a confusão existente entre o negócio fiduciário e o negócio simulado quando do ressurgimento da fidúcia no direito moderno, asseverando que tal fato constitui um dos maiores entraves ao correto conhecimento sobre o negócio fiduciário. Segundo Sousa Lima, tal confusão é provocada pela análise equivocada do negócio fiduciário por alguns autores, dentre eles, Antonio Butera e Filippo Pestalozza, que entendiam que o negócio fiduciário excedia ao meio empregado, o que resultaria num negócio simulado. Mas o que seria um negócio simulado?

Com apoio no conceito de negócio simulado concebido por Francesco Ferrara, Otto de Sousa Lima ${ }^{125}$ tece suas considerações a respeito da distinção entre a simulação e o negócio fiduciário. Para ele, na simulação há uma divergência entre a declaração e a vontade, havendo um flagrante contraste entre a forma extrínseca e a essência íntima, ao passo que, no negócio fiduciário, o ato é querido pelas partes tanto na

\footnotetext{
${ }^{123}$ GOMES, op. cit., p. 23.

${ }^{124}$ LIMA, op. cit., p. 275-279.

${ }^{125}$ LIMA, op. cit., p. 291.
} 
sua forma quanto na sua essência. O fiduciário não é um titular ficto, mas, sim, um titular real da coisa a ele entregue.

Pontes de Miranda ${ }^{126}$ ensina que, para a caracterização do defeito do negócio simulado, é necessário "que haja a intenção de prejudicar terceiros ou de violar regra jurídica, sendo tal intenção o elemento necessário do suporte fático dos incisos $102^{127}$ do Código Civil.” Dessa forma, para o conceituado jurista, o negócio fiduciário não é negócio simulado, pois ele exprime um efetivo e sério querer, apesar da desconexão entre o meio jurídico utilizado e o fim pretendido ${ }^{128}$.

Com fulcro em tais ponderações de Pontes de Miranda e também nas conclusões de José Beleza dos Santos, Heleno Taveira Tôrres ${ }^{129}$ explica:

Realmente, enquanto no negócio jurídico fiduciário persegue-se um escopo atípico, que não é próprio de qualquer esquema negocial; pela simulação relativa, as partes perseguem um escopo típico que, no todo ou em parte, é próprio de um negócio jurídico típico diferente daquele aparentemente existente, ou mesmo uma ficção, na simulação absoluta, ambos como meio para servir de pressuposto para uma tutela dos terceiros que tenham confiado na situação aparente. Eis o que o qualifica e demonstra sua diferença em relação aos atos simulados, pois nos negócios jurídicos fiduciários os efeitos são conhecidos, desejados e manifestados pelas partes, de forma lícita e sem qualquer interesse de causar prejuízo a outrem (simulação relativa), ou porque a vontade é desejada efetivamente e não se trata de uma ficção (simulação absoluta).

Como bem observa Melhim Chalhub ${ }^{130}$, também com apoio na doutrina de Pontes de Miranda, a principal distinção entre o negócio fiduciário e o

\footnotetext{
${ }^{126}$ MIRANDA, Francisco Cavalcanti, Tratado de Direito Privado, t. IV, $1^{\text {a }}$ ed. Campinas: Bookseller, 2000, p. 373.

${ }^{127}$ Correspondente ao atual artigo 167 do Código Civil.

${ }^{128}$ MIRANDA, op. cit., p. 375.

${ }^{129}$ Em seu trabalho, Heleno Taveira Tôrres cita valiosa lição de José Beleza dos Santos acerca da distinção entre negócio fiduciário e simulação. Para renomado autor, "na simulação o acordo para simular representa uma convenção que se contrapõe ao acordo aparente que no ato simulado se exibe. Nos atos fiduciários, o pacto negativo entre transmitente e adquirente completa apenas o contrato positivo da transmissão e, como os seus efeitos apenas incidem sobre as relações entre fiduciante e fiduciário, esse pacto não interessa a terceiros." SANTOS, José Beleza dos, A simulação em Direito Civil, 2. ed., São Paulo: Lejus, 1999, p. 93, apud TÔRRES, Heleno Taveira, Simulação de atos e negócios jurídicos - pacto simulatório e causa do negócio jurídico, In JUNQUEIRA DE AZEVEDO, Antonio; TÔRRES, Heleno Taveira; CARBONE, Paolo (coord.), Princípios do Novo Código civil Brasileiro e Outros Temas - Homenagem a Tullio Ascarelli, 2. ed., São Paulo: Quarter Latin, 2010, p. 334-335.

${ }^{130}$ CHALHUB, op. cit., p. 44.
} 
simulado reside "no processo de formação de vontade, na medida em que é nele que se verifica se ocorreu ou não a intenção de enganar que caracteriza a simulação."

Alfredo Buzaid segue a linha de raciocínio dos renomados juristas acima indicados e, com fulcro nos ensinamentos de Ferrara, aponta que "se efetua o negócio simulado para produzir uma aparência, um engano; o negócio fiduciário pretende suprir uma ordem jurídica deficiente e evitar certas consequências "fâcheuses" que derivam do negócio." 131 A seu ver, enquanto o negócio simulado é único e vazio de consentimento, o negócio simulado é uma combinação de dois negócios sérios, um de caráter real e outro obrigacional.

Para Darcy Bessone ${ }^{132}$, ao contrário do que sucede no negócio simulado, no negócio fiduciários não há qualquer propósito de ocultação, isto é, de simulação ou dissimulação, na medida em que o "negócio é verdadeiro, sério, real, de ponta a ponta."

Nesse sentido, Claude Reymond assinala que:

[...] o ato fiduciário foi por muito tempo tratado como um caso de simulação. Mas, no ato fiduciário, diferentemente do ato simulado, a transferência dos direitos é realmente querida pelas partes. Esta vontade é decisiva: no ato simulado as partes concordam que o contrato não passará de simples aparência; na fidúcia, o ato translativo de direito é realmente querido. ${ }^{133}$

É possível afirmar, portanto, que a distinção entre negócio fiduciário e simulado é mais nítida quando este último tem caráter absoluto, ou seja, as partes não objetivam realizar qualquer negócio, mesmo tendo feito declaração. Segundo Cunha Gonçalves ${ }^{134}$, o negócio fiduciário é sempre produtor de efeitos, ao passo que, na simulação absoluta, nenhuma modificação ocorre na relação jurídica.

Contudo, assinala o aludido autor, o quadro muda de figura quando a simulação for relativa, pois, neste caso, a declaração das partes é feita, porém de forma diversa do que aparenta, o que dificultaria a distinção entre os institutos ora examinados.

\footnotetext{
${ }^{131}$ BUZAID, op. cit., p. 35.

132 BESSONE, Darcy, Direitos reais, São Paulo: Saraiva, 1988, p. 454.

${ }^{133}$ REYMOND, Claude, op. cit., p. 23. (Tradução livre de "l'acte fiduciaire ait été longtemps traité comme um cas de simulation. Mais, dans l'acte fiduciaire, à la différence de l'acte simule, le transfert de droits est réellement voulu par les parties. Cette volonté est décisive: dans l'acte simule les parties conviennent que leur contrat ne sera qu'une simple apparence; dans la fiducie, l'acte translatif de droits est réellement voulu.")

${ }^{134}$ GONÇALVES, op. cit., p. 233.
} 
Para Sousa Lima ${ }^{135}$, na simulação relativa, há dois negócios, um sério e outro aparente, servindo o segundo para mascarar o primeiro. Apesar de efeitos menores do que a simulação absoluta, na simulação relativa ainda persiste a divergência entre a declaração e a vontade.

Darcy Bessone ${ }^{136}$ explica que, ao contrário do que acontece na simulação absoluta, na simulação relativa há um contrato aparente simulado, e um outro que se dissimula, mas que existe. O primeiro somente existe para ocultar o segundo. Como exemplo de simulação relativa referido autor cita a seguinte hipótese: a venda de um imóvel pelo ascendente ao descendente, que, para escaparem à proibição legal, simulam a venda do imóvel a um terceiro. Esta venda é simulada, para ocultar o negócio verdadeiro (o dissimulado), que é a venda do ascendente para o descendente, sem o consentimento dos demais descendentes.

Objetivando rechaçar qualquer dúvida que possa pairar sobre a distinção entre negócio fiduciário e simulação relativa, Orlando Gomes ${ }^{137}$ cita, resumidamente, a seguinte linha demarcatória entre referidos institutos elaborada por Ferrara:

1) o negócio simulado é um negócio ficto, não real; o negócio fiduciário é um negócio querido e existente.

2) o negócio simulado se realiza para suscitar uma aparência, uma ilusão;

o negócio fiduciário quer suprir uma ordem jurídica lacunosa ou evitar certas consequências importunas que derivam do negócio.

3) o negócio simulado é negócio único, jejuno de consentimentos; o negócio fiduciário é a combinação de dois negócios sérios, um, de natureza real, o outro, obrigacional, em parte elidentes, com uma influência contrária.

4) o negócio simulado não pretende alcançar resultado econômico diverso do jurídico; o fiduciário quer o resultado jurídico, mas sem o correspondente resultado econômico e o meio jurídico adotado.

5) o negócio simulado é absolutamente nulo; assim, não acarreta a transferência do direito e, por isso, o simulante continua proprietário.

${ }^{135}$ LIMA, op. cit., p. 295- 296.

${ }^{136}$ BESSONE, op. cit., p. 454.

${ }^{137}$ GOMES, op. cit., p. 24. 
Destarte, diferentemente do que ocorre na simulação, seja ela absoluta ou relativa, a vontade expressa pelas partes no negócio fiduciário é séria e concreta. As partes no negócio fiduciário não escondem o negócio ou o fim pretendido, inexistindo qualquer divergência entre a vontade e a declaração feita.

A simulação está regulada no artigo 167 do Código Civil ${ }^{138}$, que a trata como causa de nulidade do negócio jurídico, ressalvado, porém, que subsistirá o que se dissimulou, se válido for na substância e na forma. $\mathrm{O}$ objetivo desta exceção à regra é proteger o direito de terceiro de boa-fé.

De qualquer modo, somente a partir do exame da vontade das partes e da estruturação do negócio será possível auferir a existência ou não do negócio simulado, porquanto é na vontade das partes que se verificará a intenção ou não das partes de enganar.

\subsubsection{O negócio fiduciário e o negócio indireto}

Para Moreira Alves ${ }^{139}$, o negócio indireto ocorre quando as partes recorrem a um negócio jurídico típico, subordinando-se à sua disciplina jurídica, para alcançar um fim prático ulterior, o qual não é usualmente alcançado por meio desse negócio.

Martorel1 ${ }^{140}$, com apoio na lição de Ferrara e de Ascarelli, define o negócio indireto como aquele em que para lograr o efeito jurídico pretendido se utiliza um caminho oblíquo, transversal. É o negócio pelo qual as partes pretendem alcançar indiretamente por meio de um negócio, cujo fim é diferente do seu normal, ou seja, correspondente à sua natureza e às suas finalidades.

Moreira Alves ${ }^{141}$ assinala que dois anos antes da formulação moderna da teoria do negócio fiduciário a partir da publicação artigo de Regelsberger datado de 1880 foi publicado o escrito de autoria de Kohler pelo qual o negócio jurídico indireto, o qual era denominado encoberto por Kohler, era diferenciado do negócio jurídico simulado.

${ }^{138}$ BRASIL. Código Civil. Art. 167. É nulo o negócio jurídico simulado, mas subsistirá o que se dissimulou, se válido for na substância e na forma.

${ }_{139}$ ALVES, op. cit., p. 6-7 - nota no 11.

${ }^{140}$ MARTORELL, op. cit., p. 132-133.

${ }^{141}$ ALVES, op. cit., p. 4. 
Acerca de tal distinção entre negócio indireto e simulado, vale salientar a lição de Tulio Ascarelli ${ }^{142}$ no sentido de que, na simulação, as partes celebram um negócio não querido, ao passo que, no negócio indireto, as partes querem de fato o negócio, objetivando submeter-se à disciplina jurídica dele e não de outro. Sem este negócio, as partes não alcançariam os fins pretendidos, os quais, embora não se identifiquem com a consecução de tais efeitos, necessariamente, os pressupõem.

Com fundamento na lição de Ascarelli acima, Alfredo Buzaid ${ }^{143}$ afirma que a alienação fiduciária em garantia é um negócio real, efetuado de acordo com as prescrições da lei, tratando-se, portanto, de um contrato típico.

Como o negócio indireto era de escasso uso prático no nosso ordenamento, era raro encontrar doutrina sobre o tema. Nesse contexto, Moreira Alves ${ }^{144}$ diz que interessante discussão acerca da validade dos negócios indiretos para constituição de garantia por meio de transmissão da propriedade passou despercebida pelos juristas e pelos tribunais brasileiros.

Contudo, esse cenário mudou no decorrer do século passado com a adoção de meios indiretos de constituição de garantia no Brasil, como a retrovenda ${ }^{145}$.

Apesar de a doutrina ser pacífica no que diz respeito à inexistência da categoria dogmática negócio jurídico indireto, o mesmo não pode se afirmar sobre a relação existente entre os negócios fiduciários e os indiretos. Parte da doutrina entende que os negócios fiduciários pertencem à classe dos negócios indiretos (Ascarelli, Greco, Cariota-Ferrara e Martorell, dentre outros), enquanto outra parte entende que o negócio fiduciário constitui uma categoria própria e especial (Regelsberger, Wulff e outros). A partir desta divisão doutrinária, surgiram três correntes contrapostas abaixo indicadas, conforme ensinamento de Martorell ${ }^{146}$ :

1) A primeira corrente entende que os negócios fiduciários estão compreendidos dentro dos indiretos. Esta teoria defendida por Cariota-Ferrara, o qual é

142 ASCARELLI, Tulio, Problemas das sociedades anônimas e direito comparado, 1. ed., Campinas: Bookseller, 2001, p. 179.

${ }^{143}$ BUZAID, op. cit., p. 35-36.

${ }_{144}^{144}$ ALVES, op. cit., p. 5.

${ }^{145}$ Como exemplo de negócio indireto, Moreira Alves descreve a operação da retrovenda com escopo de garantia da seguinte forma: "Assim, a compra e venda tem como causa a troca de coisa por dinheiro, e como escopo último (motivo) qualquer utilização da coisa pelo comprador como proprietário; já a compra e venda com fim de garantia (negócio jurídico indireto) é uma compra e venda (negócio jurídico típico) em que a causa é a desta (troca de coisa por dinheiro), mas em que o escopo último (motivo) não é aquele a que normalmente se visa quando se celebra uma compra e venda (qualquer utilização da coisa pelo comprador como proprietário), mas o de a coisa adquirida servir ao seu proprietário como garantia de pagamento de crédito. ALVES, op. cit., p. 6, nota $\mathrm{n}^{\circ} 11$.

${ }^{146}$ MARTORELL, op. cit., p. 134- 136. 
apoiado por Ascarelli, Ferrara, Kohler, Greco e Pugliati, entre outros aduz que haveria um negócio fiduciário indireto quando o procedimento consistisse no emprego de um meio que excedesse o fim pretendido, de um negócio real limitado por uma relação obrigacional, por exemplo.

2) A segunda teoria defendida pelos autores Regelsber, Wulff, Santoro-Pasarelli e Dominedò entendem que tanto os negócios fiduciários quanto os indiretos são autônomos, ambos coexistindo de forma independente.

3) A terceira teoria que entende que negam a categoria autônoma dos negócios fiduciários, não os identificando com os negócios fiduciários. Essa corrente é defendida por Graziani e Grassetti. No Brasil, Orlando Gomes ${ }^{147}$, Alfredo Buzaid ${ }^{148}$ e Moreira Alves ${ }^{149}$ compartilham deste mesmo entendimento.

De todo modo, como orienta Otto de Sousa Lima, essa discussão sobre a relação entre os negócios fiduciários e indiretos é de pequena importância, porquanto não exerce qualquer influência na conceituação dos negócios fiduciários. Para o mencionado autor, incluindo ou não os negócios fiduciários na categoria de negócios indiretos, a verdade é que o negócio fiduciário continua com a sua característica própria.

Nesse contexto, vale destacar a valiosa observação de Álvaro Villaça Azevedo sobre a necessidade de regulamentação do negócio fiduciário, posto que esta modalidade de negócio jurídico não pode permanecer "ao arbítrio das vontades privadas, com excesso de liberdade, sob pena de haver desigual tratamento jurídico." ${ }^{\prime 50}$

\subsubsection{O negócio fiduciário e a venda com reserva de domínio}

A venda com reserva de domínio é regulada pelos artigos 521 a 528 do Código Civil e somente se aplica às vendas de coisas móveis, conforme estipula o artigo $521^{151}$

Para Darcy Bessone, a venda com reserva de domínio é um contrato em que as partes, após consentirem sobre o bem e o preço, pactuam que o vendedor, num primeiro momento, somente transmitirá a posse da coisa ao comprador, reservando para si o domínio até o integral pagamento do preço avençado. Segundo renomado autor, a venda

${ }^{147}$ GOMES, op. cit., p. 26.

${ }^{148}$ BUZAID, op. cit., p. 36.

${ }^{149}$ ALVES, op. cit., p. 6, nota de rodapé no 11

${ }^{150}$ AZEVEDO, op. cit., p. 96.

151 BRASIL Código Civil. Art. 521. Na venda de coisa móvel, pode o vendedor reservar para si a propriedade, até que o preço esteja integralmente pago. 
com reserva de domínio inexistia no direito romano, tendo surgido no direito comum, posterior ao direito romano e anterior à modificações do século XIX. ${ }^{152}$

José Alfredo Ferreira de Andrade ${ }^{153}$ conceitua a venda com reserva de domínio como sendo o pacto de reserva de propriedade da coisa, "pela qual fica reservada ao vendedor a propriedade da coisa vendida embora a sua tradição se faça imediatamente após a celebração do contrato." Caso o comprador deixe de efetuar o pagamento do preço, poderá o vendedor resilir o contrato por inadimplemento da obrigação e reivindicar a coisa entregue.

No tocante à função econômica da venda com reserva de domínio, Luís Lima Pinheiro ${ }^{154}$ assinala que o objetivo do instituto é garantir o crédito do vendedor pelo preço da compra, substituindo o direito de penhor sem posse do vendedor, inadmissível em nosso ordenamento jurídico. Dessa forma, continua aludido autor, o vendedor de bens a crédito tem uma garantia oponível erga omnes e, designadamente, oponível a todos os credores do comprador, ao mesmo tempo em que permite o gozo da coisa ao adquirente, antes de efetuado o pagamento do preço.

Dada a similitude entre a venda com reserva de domínio e o negócio fiduciário, necessário se faz traçar a distinção entre tais institutos, que, apesar de terem fins semelhantes (garantia), não se confundem. Para tanto, é preciso analisar a natureza jurídica da venda com reserva de domínio, o que será feito com fundamento na brilhante lição de Darcy Bessone.

Para Bessone, a compra e venda (sem a cláusula de reserva de domínio) implica, em última análise, na troca da coisa pelo preço. Esta troca pode ser tanto atual quanto futura, com a transferência do domínio no momento em que vier a ser pago o preço. Neste caso, assinala o autor, as duas atribuições patrimoniais correspectivas (a transmissão do domínio pelo vendedor e o pagamento do preço pelo comprador) se tornarão contemporâneas da formação do contrato, na medida em que "elas se verificarão, simultaneamente, em um momento posterior ao da celebração do contrato, e em execução dele." 155

Com base nesta última hipótese, Bessone tece as seguintes considerações acerca das características da venda com reserva de domínio: (i) inexiste

\footnotetext{
${ }^{152}$ BESSONE, op. cit., p. 442-443.

153 ANDRADE, José Alfredo Ferreira de, Da alienação fiduciária em garantia, São Paulo: Livraria e Editora Universitária de Direito Ltda., 1970, p. 24.

${ }^{154}$ PINHEIRO, Luís Lima, A cláusula de reserva de propriedade, Coimbra: Livraria Almedina, 1988, p. 24.

${ }^{155}$ BESSONE, op. cit., p. 446.
} 
transferência de domínio no ato da celebração do contrato; (ii) a transmissão do domínio depende do pagamento integral do preço; (iii) a posse da coisa é transmitida ao adquirente; (iv) a falta de uma só prestação exclui o direito à transmissão de domínio; e (v) o objetivo desse mecanismo é garantir o vendedor, sem prejuízo do uso e gozo da coisa pelo comprador desde o momento da celebração do contrato. ${ }^{156}$

Assim, o que se pretende com a venda com reserva de domínio é apenas tornar contemporânea as duas atribuições patrimoniais correspectivas: a transferência do domínio da coisa pelo vendedor ao comprador e o pagamento do preço pelo comprador ao vendedor. A partir dessas considerações sobre a venda com reserva de domínio, é possível identificar os pontos que a distinguem da alienação fiduciária em garantia.

Por primeiro, na venda com reserva de domínio inexiste qualquer condição resolutiva, tal qual ocorre na alienação fiduciária, mas, sim, uma condição suspensiva, a qual está inserida no contrato de compra e venda. Afinal, na venda com reserva de domínio, a propriedade sobre a coisa somente será transmitida ao adquirente mediante o integral pagamento do preço, ao passo que, na alienação fiduciária, é o fiduciante quem transmite a propriedade para o fiduciário, propriedade esta resolúvel, que se resolve por meio do pagamento da dívida pelo fiduciante (condição resolutiva).

Além disso, José Alfredo Ferreira de Andrade ${ }^{157}$ observa que, enquanto na alienação fiduciária o vendedor recebe o preço no ato da celebração da venda, cabendo à instituição financeira a propriedade resolúvel do bem objeto da transação, na venda com reserva de domínio o preço da coisa é pago em prestações, sendo a titularidade do domínio mantida pelo vendedor a título de garantia, apesar de a transmissão da posse do bem ser transferida ao adquirente no ato da celebração do contrato.

Esse é o mesmo entendimento de Moreira Alves ${ }^{158}$, que cita as lições de Pontes de Miranda para aclarar as diferenças entre a alienação fiduciária e a venda com reserva de domínio.

Dessa forma, a venda com reserva de domínio não se confunde com a alienação fiduciária, na medida em que, apesar de guardarem certas semelhanças, são institutos diversos, com características próprias.

\footnotetext{
${ }^{156}$ BESSONE, op. cit., p. 446-447.

${ }^{157}$ ANDRADE, op. cit., p. 24.

${ }^{158}$ ALVES, op. cit., p. 35, nota de rodapé n. 59.
} 


\subsubsection{O negócio fiduciário e o compromisso de compra e venda}

Dada a relevância do compromisso de compra e venda para o desenvolvimento do mercado imobiliário no Brasil e as suas similitudes com a alienação fiduciária de bens imóveis, antes de adentrar no tópico referente à comparação dessas duas figuras, convém fazer uma análise minuciosa do compromisso, sem, no entanto, ter a pretensão de esgotar o tema.

\subsubsection{Breves notas sobre o compromisso de compra e venda}

O crescimento do setor imobiliário no Brasil serviu como campo fértil para a ampla utilização do compromisso de compra e venda para aquisição de bens imóveis. Tal fato se deve pela dificuldade encontrada pelos compradores, principalmente nos grandes centros urbanos, para adquirir um imóvel pelo preço à vista. Evidentemente há outras situações que ocasionam a impossibilidade da imediata aquisição do bem imóvel, como, por exemplo, a aquisição do imóvel de um herdeiro durante o trâmite do inventário.

Nesse contexto, o compromisso de compra e venda surgiu para atender as situações em que as partes, por algum obstáculo, seja material, seja jurídico, não reúnem condições para celebrar o contrato de compra e venda definitivo. E justamente por sua vital importância para o fomento do mercado imobiliário, o compromisso tem recebido especial atenção do legislador pátrio.

No início do século XX, os centros urbanos no Brasil sofreram um verdadeiro boom populacional. Com o intuito de trabalharem nas indústrias que surgiam naquele tempo, pessoas advindas do interior do país se dirigiam às grandes capitais, tais como São Paulo e Rio de Janeiro.

Como a maioria da população não dispunha de soma suficiente para pagar o imóvel à vista, foi desenvolvida uma espécie de contrato capaz de garantir ao vendedor o recebimento do preço parcelado, enquanto ao comprador a transferência dos direitos inerentes ao domínio. Tratava-se do compromisso de compra e venda.

$\mathrm{O}$ rápido crescimento demográfico somado à escassa oferta de moradia nas cidades originou um campo fértil para a especulação imobiliária, com o aumento vertiginoso do preço dos imóveis. Diante disso, vendedores passaram a firmar compromissos de compra e venda e deixavam de transmitir a propriedade, mesmo com a quitação do preço pelo adquirente, com fulcro no direito de arrependimento assegurado no 
artigo 1.088 do Código Civil de 1.916. Afinal, era mais vantajoso para o vendedor inescrupuloso pagar, quando muito, indenização por perdas e danos ao comprador e vender o imóvel para terceiro.

Diante desse quadro, em 1937, foi promulgado o Decreto-Lei ${ }^{\circ}$ 58/1937, que visava conter a gana dos vendedores e garantir a proteção do direito à moradia dos compradores. O legislador criou uma série de mecanismos destinados a obstar que a má-fé do promitente vendedor impedisse a aquisição do bem imóvel pelo promitente comprador após a quitação do preço.

Como o Decreto-Lei $n^{\circ}$ 58/1937 destinava-se exclusivamente aos imóveis loteados, em 1949, foi promulgada a Lei no 649/49, estendeu os mecanismos de proteção ao direito à moradia aos adquirentes de imóveis não-loteados.

Posteriormente, mais duas leis versando sobre compromisso de compra e venda passaram a vigorar no Brasil: a Lei $\mathrm{n}^{\circ}$ 4.951/64, que trata dos imóveis incorporador a preço de custo ou por administração, e a Lei $n^{\circ}$ 6.766/79, a chamada Lei de Parcelamento de Solo Urbano, que regulamente a matéria concernente a loteamentos urbanos.

Sílvio de Salvo Venosa ${ }^{159}$ afirma que a legislação acima mencionada garantiu ao promitente comprador a transferência dos "poderes inerentes ao domínio, ius utendi, fruendi et abutendi." Por outro lado, o promitente vendedor conserva para si apenas a nua-propriedade até o pagamento integral do preço pelo adquirente. Nesse caso, renomado autor explica que o direito de dispor do bem imóvel não é totalmente transferido ao promitente comprador, "mas esmaece para o vendedor à medida que o preço é pago, até desaparecer com a solução integral."

Segundo a precisa definição do Professor Álvaro Villaça Azevedo, o contrato preliminar é "a convenção de que se valem as partes, em uma fase inicial de entabulamento de negócio, para obrigarem, ou uma delas, à outorga futura de um contrato definitivo." 160

Constata-se, portanto, que o contrato preliminar cuida-se de promessa pelo qual as partes, ou uma delas, prometem celebrar futuramente outro contrato, desta vez o principal. A grande vantagem do contrato preliminar é assegurar a celebração do contrato prometido, quando houver algum empecilho para seu imediato entabulamento.

${ }^{159}$ VENOSA, Sílvio de Salvo. Direito civil: contratos em espécie, vol. 3. $6^{a}$ ed. São Paulo: Atlas, 2006, p. 513.

${ }^{160}$ AZEVEDO, Álvaro Villaça. Teoria geral dos contratos típicos e atípicos. $3^{\mathrm{a}}$ ed. São Paulo: Atlas, 2009, p. 66. 
O contrato preliminar passou a ser regulado pelo atual Código Civil em seus artigos 462 a 466, que estabelece que a forma do pré-contrato deve apresentar os mesmos requisitos essenciais do contrato definitivo a ser firmado entre as partes.

O entendimento majoritário da doutrina é de que o contrato preliminar não gera efeitos substanciais, pois seu objeto se reduz à celebração futura do contrato principal, este sim capaz de gerar efeitos substanciais entre as partes. Por exemplo, em situações em que a coisa for alheia ou futura ou a celebração do contrato principal depender de consentimento de terceiro.

Contudo, quando o contrato preliminar visa garantir o recebimento do preço parcelado, como é o caso do compromisso de compra e venda, parte da doutrina entende se tratar de contrato definitivo. Nesse sentido, Eduardo Tristão ensina:

Não há novas obrigações a serem criadas pelo contrato definitivo. A posse direta foi transmitida; o preço, pago. Resta ao compromitente vendedor, apenas, a mera obrigação de outorgar escritura definitiva de alienação de um bem que, economicamente, já não se encontra mais em seu patrimônio e cuja recusa não lhe é deferida, sob pena de suprimento de sua vontade por determinação judicial.

Note-se, destarte, que o domínio, no compromisso de compra e venda, é empregador com a simples finalidade de garantia. Mantém-no o compromitente enquanto não quitadas as obrigações de pagar do compromissário. Percebe-se aqui a íntima relação entre compromisso de compra e venda e contrato definitivo. Os objetivos visados pelas partes são exatamente os mesmo. Diferem, basicamente, no que tange ao momento em que será cumprida a obrigação do (compromitente) vendedor. $^{161}$

Diante de tais considerações, tem-se que o compromisso de compra e venda é um contrato preliminar impróprio, na medida em que os poderes inerentes à propriedade são transferidos ao promitente comprador, enquanto o vendedor conserva tãosomente a propriedade nua. $\mathrm{O}$ direito do promitente vendedor vai se tornando cada vez mais escasso conforme o preço vai sendo pago.

O compromisso é contrato preliminar atípico porque os tradicionais poderes inerentes ao domínio são transmitidos ao compromissários comprador, enquanto

161 TRISTÃO, Eduardo. Compromisso de compra e venda: contribuições para o estudo de sua natureza, Revista do Direito Imobiliário, São Paulo, ano 32, n. 67, p-19-69, jul-dez/2009. 
ao vendedor resta a chamada "recordação do domínio", que é menos que a mera nua propriedade, na medida em que se esvazia gradativamente com o pagamento do preço pelo compromissário comprador.

Os Tribunais também entendem que a carga negocial, o conteúdo econômico do negócio e as práticas se encontram no primeiro contrato - compromisso de compra e venda - e não no contrato definitivo.

Vale destacar que nem todo compromisso de compra e venda pode ser considerado como sendo contrato preliminar impróprio. Muitas vezes pode ocorrer de o compromisso ser celebrado sem, contudo, ser transmitida a posse do imóvel ao promitente comprador. O entabulamento do compromisso pode visar tão-somente a celebração do contrato definitivo até que se reúna todos os documentos necessários para tanto.

Portanto, a pedra de toque do compromisso de compra e venda reside na transmissão da posse: quando a posse do imóvel é transmitida ao promitente comprador, tem-se o contrato preliminar atípico.

\subsubsection{A natureza jurídica do compromisso de compra e venda}

A doutrina não é pacífica quanto à natureza jurídica do compromisso de compra de venda, sendo possível identificar cinco correntes doutrinárias distintas:

1) Parte da doutrina afirma que a natureza jurídica do compromisso de compra me venda é a de direito real de garantia, na medida em que o referido contrato confere ao vendedor uma garantia de recebimento do preço, consistente no próprio imóvel objeto do compromisso.

2) Alguns doutrinadores entendem que o compromisso é direito real de gozo, por permitir ao adquirente o direito de usar, gozar e dispor do bem, sem, contudo, afetá-lo ao pagamento preferencial do credor.

3) Segundo Joel Dias Figueira Jr. ${ }^{162}$, o registro do compromisso de compra e venda no Registro de Imóveis trata-se de direito real de aquisição, "voltado a garantir, efetivamente, aquele que se compromete a adquirir um imóvel.” De acordo com essa corrente, também defendida por Washington de Barros Monteiro e Carlos Alberto

${ }^{162}$ FIGUEIRA JR., Joel Dias. In SILVA, Regina Beatriz Tavares da (coord.). Código Civil Comentado. $6^{\mathrm{a}}$ ed. rev. e atual. São Paulo: Saraiva, 2008, p. 1523. 
Dabus Maluf ${ }^{163}$, o compromisso tem natureza jurídica de direito real de aquisição, justamente por ser registrado no Registro de Imóveis.

4) Outra parte da doutrina confere ao compromisso a natureza jurídica de direito real de propriedade, na medida em que a quitação do preço do imóvel automaticamente transferiria a propriedade do imóvel ao promitente comprador.

5) Por fim, a quinta corrente assinala que o compromisso de compra e venda é um direito real sui generis, pois sua natureza não se enquadra em nenhuma outra. Para esses estudiosos o compromisso trata-se de mera limitação do poder de disposição do proprietário sobre o imóvel. Conforme ensina Maurício Bunazar ${ }^{164}$, o compromisso é direito real sui generis, pois está "em trânsito para aquisição da propriedade."

\subsubsection{As principais obrigações do compromissário comprador e do promitente vendedor}

A principal prestação do compromissário comprador e do promitente vendedor é a celebração do contrato definitivo de compra e venda. A obrigação é recíproca. Ambas as partes devem tomar todas as medidas cabíveis para alcançar o objetivo final do compromisso: a outorga escritura de compra e venda do bem imóvel.

Para tanto, também se faz necessária a prestação de natureza acessória, tais como a apresentação de documentos, o pagamento do preço, a obtenção de alvará administrativo, etc. Além disso, as partes também devem obedecer aos chamados deveres laterais de conduta, consistentes na proteção, esclarecimento e lealdade.

Após a quitação do preço e cumprimento de todas as obrigações estipuladas no compromisso, o compromissário comprador passa a ter o direito real sobre o imóvel, cabendo ao promitente vendedor outorgar a escritura definitiva. Na hipótese de haver recusa do promitente vendedor em cumprir a sua parte da obrigação, a lei faculta ao

\footnotetext{
${ }^{163}$ MONTEIRO, op. cit., p. 381, in verbis: "O instituto jurídico da promessa de compra e venda, na forma prevista no Código Civil de 2002, nasce com o registro do instrumento público ou particular, celebrado entre as partes, no Cartório de Registro de Imóveis, mas não confere ao promitente- comprador direito real, equiparável ao direito de propriedade.

O que ocorre é a existência de um novo direito real, voltado a garantir, efetivamente, aquele que se compromete a adquirir um imóvel. Trata-se, em outras palavras, de direito à aquisição para o futuro."

${ }^{164}$ BUNAZAR, Maurício. Do compromisso de compra e venda: uma estrutura naturalmente funcionalizada. In DELGADO, Mário Luiz; ALVES, Jones Figueiredo (coord.). Novo código civil: questões controvertidas - volume 7. São Paulo: Editora Método, 2006.
} 
compromissário comprador reclamar a outorga da escritura definitiva ou a adjudicação compulsória, na forma do artigo 1418 do Código Civil ${ }^{165}$.

A jurisprudência firmou o entendimento de que é desnecessário o registro do compromisso de compra e venda no Registro de Imóveis para propositura da ação de adjudicação compulsória. Neste sentido, destaca-se a Súmula 239 do STJ:

$\mathrm{O}$ direito à adjudicação compulsória não se condiciona ao registro do compromisso de compra e venda no cartório de imóveis."

Por outro lado, parte da doutrina, com destaque para Joel Dias Figueira Jr. ${ }^{166}$, entende que o ajuizamento da ação adjudicatória está condicionado ao prévio registro do compromisso de compra e venda irretratável no Registro de Imóveis. Sem o registro, o compromisso gerará apenas direitos obrigacionais. Segundo o mencionado autor, o Código Civil é expresso neste sentido, estando a Súmula 239 do STJ tacitamente revogada.

A ação de adjudicação compulsória tem natureza declaratória, na medida em que visa tão-somente declarar/reconhecer o direito real de propriedade efetivamente adquirido pelo compromissário comprador advinda da quitação integral do preço. Dessa forma, a ação adjucatória não está sujeita a prazo prescricional, pois se trata de direito potestativo.

\subsubsection{Distinção entre alienação fiduciária e o compromisso de compra e venda}

Darcy Bessone ${ }^{167}$ observa que a venda com reserva de domínio e o compromisso de compra e venda são contratos co-irmãos. Em ambos: (i) inexiste transferência de domínio no ato da celebração do contrato; (ii) a transmissão do domínio depende do pagamento integral do preço; (iii) a posse da coisa é transmitida ao adquirente; (iv) a falta de uma só prestação exclui o direito à transmissão de domínio; e (v) o objetivo desse mecanismo é garantir o vendedor, sem prejuízo do uso e gozo da coisa pelo comprador desde o momento da celebração do contrato.

\footnotetext{
165 BRASIL. Código Civil. Art. 1.418. O promitente comprador, titular de direito real, pode exigir do promitente vendedor, ou de terceiros, a quem os direitos deste forem cedidos, a outorga da escritura definitiva de compra e venda, conforme o disposto no instrumento preliminar; e, se houver recusa, requerer ao juiz a adjudicação do imóvel.

166 FIGUEIRA JR., op. cit., p. 1523.

${ }^{167}$ BESSONE, op. cit., p. 446-447.
} 
Mencionado autor pontua que a única diferença entre eles é de ordem técnica, na medida em que no compromisso de compra e venda o legislador considerou necessários dois contratos sucessivos, um de promessa de compra e venda e, outro, de compra e venda (escritura).

Diante dessas considerações, é possível afirmar que, assim como ocorre na venda com reserva de domínio, no compromisso de compra há uma condição suspensiva: a propriedade remanesce na titularidade do vendedor, que somente estará obrigado a transmiti-la ao adquirente quando ocorrer o integral pagamento do preço.

Essa característica acaba por distinguir o compromisso da alienação fiduciária. Nesta, o vendedor transmite imediatamente a propriedade ao fiduciário, normalmente instituição financeira, mediante o integral pagamento do preço. A propriedade do fiduciário é resolúvel, porquanto se resolve automaticamente através do pagamento da dívida pelo fiduciante (condição resolutiva), quando, então, a ele é transmitida.

Enquanto na alienação fiduciária o vendedor recebe o preço no ato da celebração da venda, cabendo à instituição financeira a propriedade resolúvel do bem imóvel objeto da transação, no compromisso o preço da coisa imóvel é pago em prestações, sendo a titularidade do domínio mantida pelo promitente vendedor a título de garantia, apesar de a transmissão da posse do bem ser transferida ao adquirente no ato da celebração do compromisso.

Como será visto adiante, na hipótese de inadimplemento do fiduciante na alienação fiduciária, a propriedade é consolidada na pessoa do fiduciário, que, por sua vez, deverá levá-lo a leilão extrajudicial, entregando ao devedor eventual saldo obtido no leilão. Já no compromisso, o promitente vendedor será restituído na propriedade do bem imóvel, devendo restituir as parcelas pagas pelo compromissário comprador, deduzidas as despesas e encargos.

Para Marcelo Terra ${ }^{168}$, a desvantagem do compromisso em relação à alienação fiduciária diz respeito à necessidade de a transmissão do domínio naquele primeiro instituto depender de nova declaração de vontade das partes, ou provimento judicial por meio da ação de adjudicação compulsória, substituidor da declaração de vontade do promitente vendedor. Na alienação fiduciária, por sua vez, a manifestação de

${ }^{168}$ TERRA, op. cit., p. 84 . 
vontade do vendedor ocorre num único ato, o que representa uma inegável vantagem ao comprador.

Ressalve-se que o $§ 1^{\circ}$ do artigo 25 da Lei $n^{\circ} 9.514 / 97$ prevê que, na hipótese de o fiduciário deixar de fornecer o respectivo termo de quitação no prazo de trinta dias a contar do pagamento da dívida pelo fiduciante, incidirá multa em favor deste, equivalente a meio por cento ao mês, ou fração, sobre o valor do contrato. Todavia, a lei do SFI não estipulou a medida cabível em caso de o fiduciário se recusar a emitir o termo de quitação. Nesse caso, a nosso ver, o fiduciante poderá optar entre ajuizar ação de obrigação de fazer, a fim de obrigar o fiduciário a emitir o termo de quitação, ou ação de adjudicação compulsória, cuja sentença transitada em julgado substituirá a manifestação de vontade do fiduciário, tal qual ocorre no compromisso de compra e venda.

No tocante à vantagem do compromisso em relação à alienação fiduciária, Marcelo Terra aduz:

Paralelamente à referida desvantagem, o compromisso de compra e venda traz a vantagem (inegável em certos casos concretos) de opção, pelo empreendedor, entre o direito de considerar resolvido o contrato (em face do inadimplemento da obrigação de pagamento do preço), retomando o imóvel alienado, ainda que enfrentando os obstáculos do art. 53, do Código de Defesa do Consumidor, e o direito de, considerando vencida por antecipação toda a dívida, cobrá-la judicialmente, renunciando, aqui, ao direito de retomada ao bem.

Ao optarem pela venda e compra com pacto adjeto de alienação fiduciária em garantia as partes automaticamente renunciam ao direito de realização do leilão extrajudicial da lei $n^{\circ} 4.591 / 64$ e da lei $n^{\circ} 4.864 / 65$, ou do procedimento do art. 32, da lei do parcelamento do solo urbano $\left(\mathrm{n}^{\circ}\right.$ $6.766 / 79){ }^{169}$

\subsection{A natureza jurídica da alienação fiduciária de bens imóveis}

Feitas tais considerações acerca do negócio fiduciário e figuras afins, é possível afirmar que a alienação fiduciária em garantia é instituto sui generis tipicamente brasileiro, o qual, apesar de se assemelhar com alguns institutos, nasceu e se

${ }^{169}$ TERRA, op. cit., p. 84. 
desenvolveu de forma autônoma, observando as peculiaridades da realidade comercial brasileira.

Elucidada as questões atinentes à distinção da alienação fiduciária em garantia com os demais institutos afins, este tópico focará no estudo na natureza jurídica da alienação fiduciária em garantia.

\subsubsection{A alienação fiduciária de bem imóvel é contrato bilateral sem cunho obrigatório}

Todo contrato é um negócio jurídico bilateral, na medida em que nasce de um acordo de vontades. Entretanto, existem negócios jurídicos que, apesar de surgirem de uma manifestação bilateral de vontades, podem ser classificados como contratos unilaterais.

Como bem assinala Álvaro Villaça Azevedo ${ }^{170}$, essa classificação poderia parecer incongruente, já que o contrato se forma com vontades. Porém, o que é levado em consideração neste caso é o aspecto das obrigações dos contratantes assumidas no contrato sob o ângulo dos seus efeitos.

Assim, nos contratos unilaterais apenas uma das partes assume obrigações, como acontece, por exemplo, no contrato de mútuo, no qual, o mutuário, após receber determinada quantia em dinheiro, é obrigado a devolvê-la ao mutuante após determinado período.

Em relação aos contratos bilaterais, ambas as partes contratantes assumem obrigações. A compra e venda é o clássico exemplo de contrato bilateral: enquanto o comprador assume a obrigação de pagar o preço da coisa, o vendedor assume a obrigação de entregá-la o bem ao comprador.

Nesse contexto e com base no artigo 22 da Lei $n^{\circ}$ 9.514/97, depreende-se que o contrato de alienação fiduciária de bem imóvel é um contrato bilateral análogo aos demais contratos que objetivam a constituição de garantia real (penhor, hipoteca e anticrese), pois visa à transferência da propriedade de bem imóvel com o escopo de garantia de determinada obrigação.

Assim como os contratos de penhor, hipoteca e anticrese são considerados contratos, na forma do artigo 1.424 do Código Civil, o mesmo ocorre, de forma análoga, com o contrato de alienação fiduciária. Entretanto, esta última modalidade

${ }^{170}$ AZEVEDO, op. cit., p. 70-71. 
de contrato não se confunde com os demais direitos reais de garantia (penhor, hipoteca e anticrese), porque nestes existe um direito real limitado ${ }^{171}$, já que o credor tem garantia real sobre coisa alheia, ao passo que, na alienação fiduciária, ocorre a transferência da titularidade do bem, passando o credor a ter direito real sobre a própria coisa.

Em contraposição a tal entendimento, Álvaro Villaça Azevedo afirma que a alienação fiduciária em garantia é um direito real limitado, "porque tem escopo de garantia e especial porque sobre a coisa própria é que pode ser ilimitado, quando com o descumprimento obrigacional passar à propriedade plena do credor-fiduciário."172

Conforme já exposto, o contrato de alienação fiduciária não tem cunho obrigacional, na medida em que inexiste vontade de obrigar-se, mas apenas de constituir um direito real de garantia, no caso, a propriedade fiduciária. Dessa forma, a alienação fiduciária em garantia não se situa no campo do direito das obrigações, mas, sim, no plano do direito das coisas, porquanto o contrato per si não gera obrigações para as partes.

Esse é o entendimento de Moreira Alves, que, com base na Einigung do direito alemão, assim preleciona:

A alienação fiduciária em garantia é negócio jurídico bilateral que se situa no campo do direito das coisas, correspondendo à Einigung do direito alemão, a qual é, segundo a doutrina dominante, um dinglicher Vertrag, expressão que pode ser traduzida por contrato de direito das coisas, acordo de vontades que visa a constituir (como no caso do contrato de penhor, de hipoteca ou de anticrese) ou a transferir (como na hipótese da alienação fiduciária em garantia) direitos reais. Com efeito, a

\footnotetext{
${ }^{171}$ Neste sentido, convém transcrever a brilhante lição de San Tiago Dantas acerca dos direitos limitados e seus efeitos: "Ao lado do domínio, que é o direito real completo e, portanto, o paradigma desta categoria de direitos reais subjetivos, temos os outros direitos reais, que se chamam LIMITADOS porque o poder que tem o titular sobre a coisa não é um poder pleno, completo, não abrange as faculdades de usar, gozar e dispor. Alguns autores antigos, e até modernos, gostam de considerar os direitos limitados como sendo desmembramentos do domínio, como sendo fragmentações que o domínio sofre pela transferência de certos poderes do proprietário a terceiros. Esta concepção torna-se conveniente quando se está examinando a figura do proprietário que concede direitos reais limitados sobre sua coisa, mas não deixa de ser uma construção artificial. Na verdade, em cada um dos outros direitos reais, o que há são direitos limitados, mas, desde o momento sobre uma coisa incidem, simultaneamente, a propriedade e um direito real limitado, este último comprime a propriedade e, então, se diz que ela se tornou propriedade menos plena, propriedade restrita ou propriedade limitada. A propriedade é plena quando tem por objeto uma coisa sobre a qual não recai qualquer outro direito real; e é limitada quando, ao mesmo tempo, incidem sobre a coisa um direito de propriedade e um direito real limitado.” DANTAS, Francisco Clementino San Tiago, op. cit., p. 16-17.

${ }^{172}$ AZEVEDO, Álvaro Villaça, Alienação fiduciária de bem imóvel. In: Direito civil e processual civil. Vol. 1. Porto Alegre: Magister, 2004, p. 41-49, p. 42.
} 
alienação fiduciária em garantia visa a transferir direito de propriedade limitado pelo escopo de garantia (propriedade fiduciária). ${ }^{173}$

\title{
3.4.2. A alienação fiduciária imobiliária é contrato típico e causal
}

\begin{abstract}
Álvaro Villaça Azevedo explica que a terminologia "contratos nominados" teve sua origem no direito romano, na medida em que tinham tratamento legislativo próprio, enquanto os "contratos inominados" não possuíam nome específico, já que não eram regulados pelo ordenamento jurídico. Villaça pondera que, atualmente, existem contratos que têm nome, porém não são nominados, razão pela qual ele prefere fazer referência a contratos típicos ou atípicos, sendo que os primeiros referem-se aos contratos cujos moldes são previstos em lei e os segundos não. ${ }^{174}$
\end{abstract}

Além disso, conforme visto, pelo princípio da taxatividade ou do numerus clausus somente é possível criar, alterar ou extinguir direitos e garantias reais através de lei, que, conforme ensina José de Oliveira Ascensão, "contenha a descrição essencial de uma dada situação; estabeleça para ela um regime real." 175

Diante disso, depreende-se que o contrato de alienação fiduciária é típico ou nominado, porquanto possui tratamento legislativo específico, qual seja, os artigos 22 a 33 da lei do SFI. ${ }^{176}$

Segundo Pontes de Miranda, "a causa é a função, que os sistema jurídico reconhece a determinado tipo de ato jurídico, função que o situa no mundo jurídico, traçando-lhe e precisando-lhe a eficácia." 177

As espécies de causa são: causa credenci, causa solvendi e causa donandi. Todas elas podem resultar tanto de suporte fático, no qual a vontade ou se origina da atribuição patrimonial ou da vontade daquele a quem se atribui. ${ }^{178}$

No que diz respeito à prestação de garantia, Pontes de Miranda explica que ela pressupõe de uma relação jurídica "entre o que presta e o que é credor, ou

\footnotetext{
${ }^{174}$ AZEVEDO, op. cit., p. 68.

175 ASCENSÃO, José Oliveira, A tipicidade dos direitos reais, Lisboa: [s.n], 1968, p. 121.

${ }^{176}$ Nesse sentido, Moreira Alves assevera: “A alienação fiduciária em garantia é contrato jurídico bilateral [...]. E é contrato nominado, que se enquadra entre os negócios jurídicos a que a dogmática moderna dá a denominação de negócios jurídicos dispositivos." ALVES, José Carlos Moreira, Da fidúcia romana à alienação fiduciária em garantia no direito brasileiro, In: Contratos nominados - doutrina e jurisprudência, Coordenador: Yussef Said Cahali, São Paulo: Ed. Saraiva, 1995, p. 28.

${ }_{177}^{17}$ MIRANDA, Pontes de, Tratado de Direito Privado, t. III, Campinas: Bookseller, 2001, p. 107.

${ }^{178}$ MIRANDA, op. cit., p. 111-117.
} 
entre o credor e outrem que a favor de quem se presta" ${ }^{179}$. Continua Pontes de Miranda, afirmando que, embora se trate de segurança, na prestação de garantia a causa é solvendi.

Para fins do presente estudo, o contrato de alienação fiduciária é um título causal para o surgimento da propriedade fiduciária, com fundamento no pacto de fidúcia, conforme ensina Orlando Gomes ${ }^{180}$.

Ao discorrer sobre a causa do negócio fiduciário, Heleno Taveira Tôrres $^{181}$ ensina que a fidúcia pode ter por objetivo tanto a garantia quanto a administração de determinado bem. A chamada causa fiduciae não é o fim do mandato ou da garantia, mas, sim, a causa, a justificativa, para a transferência da coisa (meio que excede o fim), que limita a própria transmissão da propriedade refletida na obrigação do fiduciária de restituir a coisa ao fiduciante. Assim, sem a causa fiduciae inexiste negócio fiduciário.

Entretanto, o entendimento emanado por Heleno Tôrres a respeito da causa do negócio fiduciário não é o mesmo para a alienação fiduciária, como assinala Nelson Rodrigues Netto. Para este autor, a causa na alienação fiduciária não se equivale exatamente à causa fiduciae, mas, sim, à vantagem econômica buscada por ambas as partes. Rodrigues Netto explica que, para o devedor-fiduciante, a vantagem configura-se na possibilidade de utilizar-se da propriedade fiduciária em garantia de outro negócio jurídico, pelo qual obtém um crédito. Por outro lado, a vantagem do credor-fiduciário está justamente na transferência da titularidade da propriedade fiduciária, que garante o crédito outorgado, já que, na hipótese de inadimplemento, a propriedade da coisa será consolidada na pessoa do credor-fiduciário. ${ }^{182}$

Não obstante tal entendimento, Mehim Chalhub ${ }^{183}$ assinala que, por possuir uma estrutura complexa, a doutrina não é pacífica quanto à estrutura do negócio fiduciário no que diz respeito à sua causa.

A primeira tese denominada doutrina dualista entende que o negócio fiduciário se resultaria da conjugação de dois contratos, um contrato real positivo, consistente na transferência da propriedade ao fiduciário com escopo de garantia, e outro, contrato obrigatório negativo, pelo qual se estipula a obrigação do fiduciário de restituir

\footnotetext{
${ }^{179}$ MIRANDA, op. cit., p. 111-112.

${ }^{180}$ GOMES, op. cit., p. 45-46.

${ }^{181}$ TÔRRES, op. cit., p. 333-334.

182 RODRIGUES Netto, Nelson, A evolução fiduciária em garantia, In: Revista do Curso de Direito do Centro Universitário das Faculdades Metropolitanas Unidas, UniFMU, ano XVIII, nº 26, 2004, p. 33-63, p. 39.

${ }^{183}$ CHALHUB, op. cit., p. 41.
} 
coisa verificado o implemento da condição. Essa tese é chamada dualista e, conforme exposto, foi concebida por Goltz. ${ }^{184}$

A segunda corrente chamada de tese unitária ou monista foi concebida por Grassetti defende que o negócio fiduciário seria um só negócio, decorrendo da causa fiduciae (i) efeitos reais, oponíveis erga omnes e (ii) efeitos obrigacionais, de alcance interno.

De qualquer forma, a lei do SFI cuidou de eliminar e regular o pacto de fidúcia, permitindo às partes apenas os termos da condição para o qual a propriedade fiduciária é contratada.

\subsubsection{A alienação fiduciária imobiliária é contrato acessório}

San Tiago Dantas na sua célebre obra "Programa de Direito Civil III", ao discorrer sobre os direitos reais de garantia, aponta as seguintes características gerais do referido instituto: (i) a acessoriedade; (ii) a sequela; (iii) a preferência; (iv) a sua sub-rogação; e (v) a sua indivisibilidade. ${ }^{185}$

Dentre tais características dos contratos que são títulos constituintes de direitos reais de garantia, a acessoriedade se faz presente na alienação fiduciária em garantia de forma mais nítida, conforme observa Moreira Alves ${ }^{186}$.

A acessoriedade inerente aos títulos de constituição de direitos reais de garantia é definido por San Tiago Dantas nos seguintes termos:

Nos direitos sobre a substância da coisa, o direito existe por si mesmo, em virtude do ato que o criou, não assim nos direitos reais de garantia, que todos eles são acessórios de um crédito, cuja sorte acompanha. Vence-se o crédito, vence-se o direito, ou melhor, entra o direito em sua fase de execução e extingue-se o crédito, perde a razão de ser o direito real de garantia que o assegura, enfim, o direito real de garantia está orientado para o crédito por uma espécie de gravitação particular. Ele gravita na órbita do crédito; a garantia sofre a atuação e a sua influência e por ele se justifica, assim preenchendo a sua função econômica em razão

\footnotetext{
${ }^{184}$ ALVES, op. cit., p. 27.

${ }^{185}$ DANTAS, op. cit., p. 387-389.

${ }^{186}$ ALVES, op. cit., p. 90, in verbis: "Como ocorre com os contratos que são títulos de aquisição dos direitos reais de garantia, é a alienação fiduciária contrato acessório daquele que decorre o crédito que a propriedade fiduciária visa a garantir."
} 
do crédito que acompanha. Aí, uma característica fundamental e importantíssima de considerar-se nas suas numerosas situações práticas. Isto não quer dizer que o direito real de garantia não se constitua por um modo próprio. Não basta existir o crédito para que dele gere a garantia como obra de uma simples convenção. É necessário, para que o penhor surja, que se pratique o ato constitutivo do penhor, que se entregue a coisa, e, para que surja a hipoteca, que se inscreva o ato constitutivo no registro de imóveis, mas essa constituição por um ato próprio, e a acessoriedade jurídica não é mais do que a expressão de sua acessoriedade econômica. ${ }^{187}$

Em razão da sua acessoriedade, a sorte do contrato de alienação fiduciária segue a do principal. Assim, se o contrato principal for nulo ou anulável, a alienação fiduciária também será.

Contudo, há situações em que alienação fiduciária persistirá mesmo na hipótese de o contrato principal vir a ser declarado nulo: caso o contrato principal venha a ser garantido por terceiro, diverso do devedor, deixará de existir a relação de interdependência entre os contratos principal e acessório. Dessa forma, se o contrato principal estiver viciado, por exemplo, em razão da incapacidade do contratante, a garantia continuará vigente, na medida em que a exceção pessoal do devedor incapaz não lhe aproveita. $^{188}$

Marcelo Terra ${ }^{189}$ salienta que, dada a característica de acessoriedade da alienação fiduciária e não havendo qualquer óbice legal, ela poderá ser celebrada em dois momentos distintos: (i) conjuntamente com o contrato principal, seja ele de compra e venda ou de mútuo; e (ii) posteriormente à celebração do contrato principal (de compra venda ou de mútuo).

Alexandre Clápis ${ }^{190}$ observa que, apesar de o entendimento exposto por Marcelo Terra ser majoritário na doutrina, há autores, com destaque para Narciso Orlandi Neto, que entendem que a interpretação literal do inciso IV do artigo 24 da lei do SFI $^{191}$ apenas autoriza a hipótese de a alienação fiduciária de imóvel ser firmada em

${ }^{187}$ DANTAS, op. cit., p. 387.

${ }^{188}$ ALVES, op. cit., p. 91.

189 TERRA, op. cit., p. 23.

${ }^{190}$ CLÁPIS, Alexandre Laizo, A propriedade fiduciária imobiliária - aspectos gerais e registrários, 271 p. Dissertação (Mestrado) em Direito Civil. Faculdade de Direito. Pontifícia Universidade Católica de São Paulo, 2010, p. 107.

${ }^{191}$ BRASIL, Lei n ${ }^{\circ}$ 9.514/97. Art. 24. O contrato que serve de título ao negócio fiduciário conterá: 
contrato diverso do principal. Assim, seria impossível a celebração tanto da compra e venda quanto da alienação fiduciária do imóvel no mesmo contrato.

Clápis rechaça a aplicação da teoria apresentada por essa corrente doutrinária com um interessante exemplo prático, que faz parte da rotina daqueles que atuam diretamente com registros de imóveis. Confira-se:

Um simples exemplo prático pode demonstrar a fragilidade desse entendimento. Os registros de imóveis atualmente contam com diversos guichês de atendimento ao público que recebem, simultaneamente, centenas de títulos que consubstanciam inúmeros negócios jurídicos (cada qual com seu número específico de prenotação para garantia da prioridade prevista no art. 186 da Lei Federal nº 6.015/1973), além de constrições judiciais.

Durante o tempo em que o interessado efetiva a prenotação no guichê A do contrato de compra e venda, pode haver, no guichê $\mathrm{B}$, a prenotação imediatamente seguinte de uma ordem judicial de indisponibilidade de bens expedida em medida cautelar fiscal proposta em face do devedorfiduciante. Terminada a prenotação do contrato de compra e venda, o interessado solicitará a prenotação do contrato de alienação fiduciária de coisa imóvel. Assim, se o contrato de compra e venda receber o protocolo $\mathrm{n}^{\mathrm{o}} 1$, a ordem de indisponibilidade de bens o ${ }^{\circ} 2$ e a alienação fiduciária o ${ }^{\circ} 3$, prejudicada estará a constituição da propriedade fiduciária, porque fica comprometida a disponibilidade de bens do adquirente/fiduciante. Esse é um exemplo extremo, mas outras situações podem igualmente representar riscos à constituição da garantia real em favor do credorfiduciário. $\mathrm{O}$ melhor é que o mesmo contrato consubstancie ambos os negócios, a compra e venda e a alienação fiduciária. ${ }^{192}$

Por fim, as obrigações futuras ou sob condição também podem ser garantidas pela alienação fiduciária de bem imóvel, como ensinam Marcelo Terra ${ }^{193}$ e Moreira Alves ${ }^{194}$. Desse modo, um contrato de abertura de crédito, por exemplo, poderá ter como garantia um imóvel por meio da alienação fiduciária, sendo que a sua eficácia dependerá do surgimento da obrigação principal.

IV - a cláusula de constituição da propriedade fiduciária, com a descrição do imóvel objeto da alienação fiduciária e a indicação do título e modo de aquisição.

${ }_{192}$ CLÁPIS, op. cit., p. 108.

193 TERRA, op. cit., p. 23.

${ }^{194}$ ALVES, op. cit., p. 91. 
O credor-fiduciário tem, portanto, mera expectativa de direito. Afinal, a garantia real representada pela propriedade fiduciária somente será efetivamente constituída quando o crédito subordinado à condição suspensiva surgir no plano jurídico.

\subsubsection{A alienação fiduciária de bem imóvel como título constitutivo da propriedade fiduciária mediante registo}

$\mathrm{O}$ artigo 23 da lei do SFI estabelece que a propriedade fiduciária de coisa imóvel é constituída mediante registro, no competente Registro de Imóveis, do contrato que lhe serve de título. Esse preceito tem como base o sistema de aquisição de propriedade originado no direito romano, com influência do direito germânico.

Caio Mário da Silva Pereira ${ }^{195}$ explica que, antes da vigência do Código Civil de 1916, o contrato tinha força translativa, tal como ocorria no direito francês, no qual, o acordo de vontade, por si só, era suficiente para transmitir a propriedade, sem a necessidade de qualquer exigência. Cientes dos riscos dessa operação, os juristas pátrios passaram a exigir a transcrição da transferência da propriedade, a fim de que esta tivesse efeito erga omnes.

Evidentemente este sistema de aquisição de propriedade foi objeto de críticas em razão da sua nítida contradição: ao mesmo tempo em que a lei aceitava o contrato como título translativo de propriedade, ela também exigia o seu registro para que tivesse sua validade em relação a todos. Se o registro não fosse efetuado, a propriedade somente se operava inter partes, o que é inadmissível, dado que não é permitido que a propriedade tenha validade apenas e tão-somente entre as partes.

Inspirado pelo sistema germânico de aquisição de propriedade, pelo qual, segundo Moreira Alves ${ }^{196}$, os direitos reais não nascem do simples acordo de vontade, mas dependem da tradição ou transcrição para que esse acordo se perfaça, Clóvis Beviláqua, ao elaborar o Código Civil de 1916, adotou as premissas daquele sistema e as adaptou à realidade brasileira.

Assim, Caio Mário da Silva Pereira explica que, no nosso direito, o contrato deixou de operar a transferência do domínio, gerando tão-somente um direito de

\footnotetext{
${ }^{195}$ PEREIRA,Caio Mário da Silva, Instituições de direito civil, v. 4, Rio de Janeiro: Ed. Forense, 2009, p. 100-101.

${ }^{196}$ ALVES, op. cit., p. 59.
} 
crédito. Somente o registro desse título perante o Registro de Imóvel competente cria o direito real." 197

Esse mesmo sistema de aquisição de propriedade originado no Código Civil de 1916 passou a ser utilizado para constituição das garantias reais, inclusive pela lei do SFI por meio do seu artigo 23. Sem o seu registro, as garantias reais não surtem qualquer efeito, porquanto, como examinado alhures, o título não se situa no plano obrigacional, mas apenas no campo do direito das coisas.

Neste sentido, vale destacar a lição de Couto e Silva:

Mas a vontade de adimplir como decorrência lógica da vontade criadora de direitos e obrigações, somente existe naqueles casos em que o cumprimento de dever seja, a sua vez, negócio jurídico. Esta afirmativa parece óbvia, mas convém ter sempre presente que existem outros negócios dispositivos, inclusive de direito das coisas, que não se constituem em adimplemento de uma obrigação. Nos de garantia, quando alguém diz que "dá em hipoteca determinado imóvel para garantir mútuo anteriormente realizado", cuida-se de negócio de direito das coisas, negócio esse que não é decorrência lógica do mútuo, porque existem empréstimos sem garantia real, e o acordo de constituição do ônus é negócio jurídico no plano dos direitos reais. E aí se faz imprescindível a vontade dirigida à constituição do gravame. Essa, por sua vez, não se poderá considerar como implícita no mútuo. ${ }^{198}$

Dessa forma, ao determinar que a propriedade fiduciária somente será constituída através do registro do título (contrato de alienação fiduciária - título de aquisição) no Registro de Imóveis competente, o artigo 23 da Lei no 9.514/97 evidencia que, antes do registro, o que existe é um mero direito expectativo do credor-fiduciário de obter a garantia real. Apenas com o registro do contrato de alienação fiduciária (modo de aquisição), será constituída a propriedade fiduciária, tal como a hipoteca.

Portanto, não é possível conferir o atributo de oponibilidade em relação a todos (erga omnes) à propriedade fiduciária sem o registro do título no competente Registro de Imóveis.

${ }^{197}$ PEREIRA, op. cit., p. 103.

${ }^{198}$ COUTO e SILVA, Clóvis V. A obrigação como processo. Rio de Janeiro: Editora FGV, p. 53. 


\section{CAPÍTULO 4 REQUISITIOS DE VALIDADE DO CONTRATO DE ALIENAÇÃO FIDUCIÁRIA DE BEM IMÓVEL}

O artigo 104 do Código Civil ${ }^{199}$ enumera os requisitos de validade do negócio jurídico, quais sejam, agente capaz (requisito subjetivo), objeto lícito, possível, determinado ou determinável (requisito objetivo), e forma adequada (requisito formal). Dessa forma, para validade do contrato de alienação fiduciária é preciso que ele observe os mencionados requisitos legais.

\subsection{Requisito subjetivo}

O requisito subjetivo do contrato de alienação de alienação fiduciária de bem imóvel refere-se à capacidade e à legitimação dos agentes, ou seja, das partes que celebram o negócio.

Segundo Caio Mario Pereira da Silva ${ }^{200}$, a capacidade do agente é imprescindível para a validade do negócio jurídico, devendo, para tanto, ser observadas as regras estabelecidas no Código Civil atinentes às pessoas absoluta e relativamente incapazes.

Os sujeitos absolutamente incapazes são aqueles não podem praticar nenhum negócio válido. Nos termos do artigo $3^{\circ}$ do Código Civil ${ }^{201}$, são agentes absolutamente incapazes: (i) os menores de dezesseis anos; (ii) os que, por enfermidade ou deficiência mental, não tiverem o necessário discernimento para a prática desses atos; e (iii) os que, mesmo por causa transitório, não puderem exprimir sua vontade.

Em relação aos sujeitos relativamente incapazes, o artigo $4^{\circ}$ do Código Civil ${ }^{202}$ assim os enumera: (i) os maiores de dezesseis e menores de 18 anos; (ii) os

\footnotetext{
${ }^{199}$ BRASIL. Código Civil, Art. 104. A validade do negócio jurídico requer:

I - agente capaz;

II - objeto lícito, possível, determinado ou determinável;

III - forma prescrita ou não defesa em lei.

${ }^{200}$ PEREIRA, Caio Mário da Silva, Instituições de direito civil, v. 1, Introdução ao direito civil: teoria geral do direito civil, 24. ed., Rio de Janeiro, Ed. Forense, 2011, p. 405.

${ }^{201}$ BRASIL. Código Civil. Art. 3ํㅗ̃o absolutamente incapazes de exercer pessoalmente os atos da vida civil: I - os menores de dezesseis anos;

II - os que, por enfermidade ou deficiência mental, não tiverem o necessário discernimento para a prática desses atos;

III - os que, mesmo por causa transitória, não puderem exprimir sua vontade.

${ }^{202}$ BRASIL. Código Civil. Art. $4^{\circ}$ São incapazes, relativamente a certos atos, ou à maneira de os exercer:

I - os maiores de dezesseis e menores de dezoito anos;
} 
ébrios habituais, os viciados em tóxicos, e os que, por deficiência mental, tenham o discernimento reduzido; (iii) os excepcionais, sem desenvolvimento mental completo; e (iv) os pródigos.

Entretanto, qualquer dessas incapacidades poderá ser sanada, seja pela representação, no caso de incapacidade absoluta, seja pela assistência ou autorização, no caso de incapacidade relativa. Mediante tais institutos - representação, assistência ou autorização -, tanto o absolutamente quanto o relativamente incapaz poderão celebrar validamente um negócio jurídico.

Além das incapacidades genéricas, a lei prevê ainda a possibilidade de agentes capazes serem impedidos de realizar determinados negócios jurídicos por conta de motivos específicos. Essas restrições são denominadas "impedimentos" ou “incapacidades especiais" e são previstas em lei. Elas verificam em circunstâncias excepcionais quanto à realização de certos atos pelo agente capaz num caso específico. É o caso, por exemplo, do tutor que não pode adquirir, nem em hasta pública, os bens confiados à sua guarda e administração.

Inspirado pelo ramo do direito processual civil, que prevê a existência do instituto da legitimidade, que é a titularidade da pessoal para ajuizar deterinada ação, Custodio da Piedade Ubaldino Miranda ${ }^{203}$ afirma que as restrições para celebrar determinado negócio jurídico por força da posição em que o agente se encontra em relação a certos bens ou interesses estão relacionadas à sua legitimidade. Para mencionado autor, a legitimação consiste num poder de agir, sendo, pois, considerado um pressuposto, e não um requisito, para a validade do negócio jurídico.

Dessa forma, para validade dos negócios jurídicos, é necessário que o agente, além de ser capaz, não sofra qualquer diminuição instituída especificamente para o caso.

Com base em tais ponderações sobre capacidade e legitimidade dos agentes, verifica-se que o artigo 22 da lei do SFI estabelece que na alienação fiduciária em garantia de bens imóveis devem figurar dois sujeitos: o credor-fiduciário, que é aquele que recebe a propriedade imobiliária em garantia; e o devedor-fiduciante, que entrega o bem

II - os ébrios habituais, os viciados em tóxicos, e os que, por deficiência mental, tenham o discernimento reduzido;

III - os excepcionais, sem desenvolvimento mental completo;

IV - os pródigos.

${ }^{203}$ MIRANDA, Custodio da Piedade Ubaldino, Teoria geral do negócio jurídico, 2. ed., São Paulo: Atlas, p. 62-63. 
imóvel em garantia. Ambos devem ter capacidade e legitimidade para celebrar o negócio jurídico.

No tocante à legitimação, vale ressalvar interessante celeuma enfrentada pela doutrinária e pela jurisprudencial acerca de quem poderia figurar como credor-fiduciário no contrato de alienação fiduciária em garantia de bem móveis prevista na Lei ${ }^{\circ}$ 4.728/65 e no Decreto-Lei no 911/69, conforme assinala Luiz Augusto Beck da Silva:

O sujeito ativo do negócio jurídico que se estabelece entre as partes contraentes é, em regra, a pessoa jurídica que concede o financiamento, denominada de sociedade de crédito, financiamento e investimento ou simplesmente instituição financeira (v. $\S 2^{\circ}$ do art. 10 do Dec.-Lei $n^{\circ}$ 413/69, Dec.-Lei $n^{\circ}$ 60.501/67, art. $186 \S 2^{\circ}$ e Dec. $n^{\circ}$ 62.789, de 30-568). Também conhecido como credor, adquirente, fiduciário, proprietário-fiduciário, o sujeito ativo (sociedade de crédito) é constituído sob a forma de sociedade anônima, especializada basicamente em operações de abertura de crédito mediante aceite de letras de câmbio para financiamento de compra de bens e serviços, efetuadas por consumidor ou usuário final.

No entanto, o entendimento que restringe o âmbito da aplicação da alienação fiduciária em garantia não é pacífico sobretudo na doutrina. Opiniões respeitáveis sedimentam-se num e noutro lado. Assim, Alfredo Buzaid, Aderbal da cunha Gonçalves, Arnold Wald, Orlando Gomes, Oswaldo e Silvia Opitz, João Bosco Cavalcanti Lana e Paulo Barreto entendem que somente a entidade financeira pode se valer do instituto sob análise nas operações admitidas em lei, ao passo que Egon Feliz Gottschalk, Euler da Cunha Peixoto, Luiz Alberto da Silva e Jackson Rocha Guimarães defendem a tese de que a figura jurídica não é privativa das sociedades de crédito. ${ }^{204}$

Não obstante o posicionamento majoritário da doutrina favorável à limitação da figura de credor-fiduciário às instituições financeiras, Renan Miguel Saad ${ }^{205}$ aponta interessante acórdão prolatado pelo Supremo Tribunal Federal no Recurso

${ }^{204}$ SILVA, op. cit., p. 35.

${ }^{205}$ SAAD, op. cit., p. 144. 
Extraordinário $\mathrm{n}^{\circ}$ 91149-SP $\mathrm{P}^{206}$, pelo qual foi decidido ser possível a alienação fiduciária de bens adquiridos em consórcio, afastando a teoria de que somente instituições financeiras poderiam figurar como credoras-fiduciárias.

A mesma celeuma se viu também quanto à legitimidade do devedorfiduciante na alienação fiduciária de bens móveis: parte da doutrina entendia figurar que o Decreto-Lei no 911/69 restringiu a figura do devedor na alienação fiduciária ao consumidor final que havia obtido crédito para aquisição de determinado produto, enquanto outra parte entendia que qualquer pessoa poderia figurar como devedor-fiduciante. Moreira Alves ${ }^{207}$ se coaduna com a sua segunda teoria, entendendo que o termo devedor previsto no Decreto-Lei $n^{\circ}$ 911/69 deve ser interpretado extensivamente.

A par da discussão doutrinária e jurisprudencial sobre a legitimidade do credor-fiduciário e do devedor-fiduciante na alienação fiduciária de bens móveis, o legislador, ao confeccionar a Lei $n^{\circ} 9.514 / 97$, tomou a precaução de prever que a alienação fiduciária em garantia de coisa imóvel poderá ser contratada por pessoa física ou jurídica, não sendo privativa das entidades que operam no SFI.

Ressalve-se que a lei do SFI não impede que terceiro contrate a alienação fiduciária dando em garantia de um crédito outorgado a outrem um imóvel de sua titularidade. Neste sentido, Paulo Restiffe Neto e Paulo Sérgio Restiffe prelecionam:

Como interessado especial, o proprietário não devedor (portanto, não coobrigado) pode intervir no contrato como garante fiduciante e, ocupando essa especial posição de prestante, que não é coobrigado, mas responsável, alienar seu imóvel em garantia de obrigação ou dívida alheia, com responsabilidade própria de direito real limitada ao vínculo objeto que alienou, tal qual é praxe na alienação fiduciária, regida pelo Decreto-lei 413/1969.

Ainda que o art. 22 da Lei 9.514/1997 não faça menção a terceiros, essa lacuna não é irrelevante, tanto mais que suprida agora que a Lei 10.931/2004, no art. 51, expressamente autoriza, em sutil complementação ao aludido art. 22 da Lei 9.514/1997, que a garantia por

${ }^{206}$ BRASIL. Supremo Tribunal Federal. Recurso Extraordinário n ${ }^{\circ}$ 91149-SP, Rel. Min. Moreira Alves, DJ. De 5.10.79, p. 7446, RTJ 94/864, $2^{\text {a }}$ Turma. Ementa do acórdão: “Alienação fiduciária em garantia.. A garantia real (propriedade fiduciária) decorrente da alienação fiduciária em garantia pode ser utilizada nas operações de consórcio, que se situam no terreno do sistema financeiro nacional, e que se realizam sob fiscalização do poder público, da mesma forma como ocorre com as operações celebradas pelas financeiras em sentido estrito. Precedentes do STF (RE 90209, 90036 e 90652). Recurso extraordinário conhecido e provido."

${ }^{207}$ ALVES, op. cit., p. 100. 
alienação fiduciária de coisa imóvel pode ser prestada inclusive por terceiro como "fiduciante", em obrigações em geral. Podem, pois, surgir situações sui generis. E o art. 1.367 do CC de 2002, ao cuidar da fidúcia paritária móvel, faz remissão ao art. 1.427, que disciplina a prestação de garantia real por terceiro, tornando-a aplicável à alienação fiduciária codificada. $^{208}$

Assim, para celebração do contrato de alienação fiduciária em garantia de bem imóvel, basta que as partes, sejam elas pessoas naturais ou jurídicas, preencham os requisitos concernentes à capacidade, à legitimação e detenham poderes de disposição.

\subsubsection{A legitimação do condômino para alienar fiduciariamente sua parte indivisa}

O artigo 1.314 do Código Civil $^{209}$ (correspondente ao artigo 623, III, do Código Civil de 1916) autoriza o titular de direito de propriedade em condomínio voluntário de coisa indivisível, por exemplo, um apartamento, a alienar fiduciariamente a sua parte indivisa, sem o consentimento dos demais condôminos.

Além disso, por analogia, entendemos também ser possível justificar a alienação da parte indivisível pelo condômino com fulcro no $\S 2^{\circ}$ do artigo 1.420 do Código $\mathrm{Civil}^{210}$, uma vez que este dispositivo legal refere-se às garantia reais estipuladas no Código Civil (penhor, hipoteca e anticrese) e certamente pode ter sua interpretação estendida à alienação fiduciária de bem imóvel, que também consiste numa garantia real.

Moreira Alves $^{211}$, com apoio em Pontes de Miranda e no artigo 623, III, do Código Civil de 1916 (atual artigo 1.314), afirma que o fiduciante, titular da parte pro indiviso alienada fiduciariamente, perde a sua cota e o fiduciário a recebe, passando a ser comunheiro, fiduciariamente, na propriedade do bem. Essa transferência não alteração

\footnotetext{
208 RESTIFFE NETO, Paulo; RESTIFFE, Paulo Sérgio, Propriedade fiduciária imóvel, São Paulo: Malheiros Editores, 2009, p. 42-43.

${ }^{209}$ BRASIL. Código Civil. Art. 1.314. Cada condômino pode usar da coisa conforme sua destinação, sobre ela exercer todos os direitos compatíveis com a indivisão, reivindicá-la de terceiro, defender a sua posse e alhear a respectiva parte ideal, ou gravá-la.

${ }^{210}$ BRASIL. Código Civil. Art. 1.420. Só aquele que pode alienar poderá empenhar, hipotecar ou dar em anticrese; só os bens que se podem alienar poderão ser dados em penhor, anticrese ou hipoteca.

$\S 2^{\underline{o}}$ A coisa comum a dois ou mais proprietários não pode ser dada em garantia real, na sua totalidade, sem o consentimento de todos; mas cada um pode individualmente dar em garantia real a parte que tiver.

${ }^{211}$ ALVES, op. cit., p. 105.
} 
a situação jurídica entre os condôminos, na medida em que apenas e tão-somente a parte indivisível se torna de outrem, no caso, o fiduciário, que a perderá quando do cumprimento da obrigação pelo fiduciante.

Ao comentar mencionado dispositivo legal, Caio Mário da Silva Pereira $^{212}$ corrobora tal entendimento, ressalvando ser ilícita a hipótese em que o condômino grava a totalidade da coisa comum sem o consentimento de todos.

No tocante ao direito de preferência previsto no artigo 504 do Código Civil $^{213}$ (correspondente ao artigo 1.139 do Código Civil de 1916), Moreira Alves ${ }^{214}$ entende ser inaplicável tal regra na hipótese de o titular alienar fiduciariamente a sua parte pro indiviso, pois tal negócio jurídico não configura venda. Para Moreira Alves, o direito de preferência somente surgirá se o fiduciante não pagar a dívida e a parte indivisa do condomínio dada em garantia for posta à venda pelo fiduciário, a fim de recompor seu crédito. Nesse caso, compartilhamos o entendimento de Alexandre Clápis ${ }^{215}$ de que, após ser consolidado na propriedade do bem imóvel, o credor-fiduciário deverá notificar os demais condôminos para que, querendo, exerçam o direito de preferência de aquisição em relação aos demais licitantes, na forma estipulada no artigo 504 do Código Civil.

\subsection{Objeto do contrato de alienação fiduciária de bem imóvel}

O artigo 22 da Lei $n^{\circ}$ 9.514/97 estabelece que o contrato de alienação fiduciária tem como objeto bem imóvel, o qual, nos termos do artigo 79 do Código Civil, corresponde ao solo e tudo quanto se lhe incorporar natural ou artificialmente.

Os incisos I a IV do artigo 22 da lei do SFI indicam que, além da propriedade plena, também poderão ser objeto de alienação fiduciária: (i) bens enfitêuticos; (ii) o direito de uso para fins de moradia; (iii) o direito real de uso, desde que suscetível de alienação; e (iv) a propriedade superficiária. $\mathrm{O} \S 2^{\circ}$ do aludido artigo ressalva que a propriedade fiduciária sobre o direito real de uso e sobre a propriedade superficiária ficam

\footnotetext{
${ }^{212}$ PEREIRA, op. cit., p. 153.

${ }^{213}$ BRASIL. Código Civil. Art. 504. Não pode um condômino em coisa indivisível vender a sua parte a estranhos, se outro consorte a quiser, tanto por tanto. O condômino, a quem não se der conhecimento da venda, poderá, depositando o preço, haver para si a parte vendida a estranhos, se o requerer no prazo de cento e oitenta dias, sob pena de decadência.

${ }^{214}$ ALVES, op. cit., p. 105.

${ }^{215}$ CLÁPIS, op. cit., p. 83.
} 
limitados à duração da concessão ou direito de superfície, caso tenham sido transferidos por período determinado. Tais incisos foram incluídos pela Lei ${ }^{\circ} 11.481 / 2007$.

O texto original do $\S 1^{\circ}$ do artigo 22 , originalmente parágrafo único, restringia o objeto da propriedade fiduciária aos imóveis concluídos ou em construção, não autorizando que referida garantia recaísse sobre os imóveis por natureza, como, por exemplo, o solo não edificado. Referido dispositivo foi, à época, objeto de crítica de Melhim Chalhub ${ }^{216}$, que apontou a imprecisão técnica da particularização contida no parágrafo único, porquanto "bem imóvel é constituído pelo solo e por tudo aquilo que nele se incorporar permanentemente."

Com as alterações promovidas pela Lei $\mathrm{n}^{\circ} 10.931 / 2004^{217} \mathrm{e}$, posteriormente, pela Lei $\mathrm{n}^{\circ} 11.076 / 2004^{218}$, o artigo 22 da lei do SFI passou a permitir a constituição de propriedade fiduciária sobre solo não edificado.

A Lei $\mathrm{n}^{\mathrm{o}} 11.481 / 2007$, por seu turno, estendeu a possibilidade de constituição da propriedade fiduciária para aqueles institutos enumerados nos incisos II a IV, de modo a alcançar a perfeita harmonia com o disposto no artigo 79 do Código Civil.

Dessa forma, a amplitude da lei atinge tanto imóveis urbanos quanto rurais, independentemente de sua destinação - residencial, comercial, industrial, etc. Como bem salienta Melhim Chalhub ${ }^{219}$, "é passível de alienação todos e qualquer imóvel passível de alienação plena, isto é, que não esteja fora do comércio."

No tocante aos bens enfitêuticos, embora o artigo 2.308 do Código Civil tenha proibido a constituição de novas enfiteuses e subenfiteuses, houve ressalva dos aludidos direitos preexistentes, subordinando-os, às disposições contidas nos artigos 678 a 694 do Código Civil de 1916. Vale lembrar que, de acordo com o inciso I do artigo 674 do Código Civil de 1916, a enfiteuse é um contrato de natureza real, pelo qual o proprietário

\footnotetext{
${ }^{216}$ CHALHUB, Melhim Namem. Negócio fiduciário. 3. ed., rev. e atual. Rio de Janeiro: Renovar, 2006, p. 86.

${ }^{217}$ A Lei $n^{\circ} 10.931 / 2004$ alterou a redação do parágrafo único do artigo 22 da lei do SFI para os seguintes termos: "A alienação fiduciária poderá ter como objeto bens enfitêuticos, sendo também exigível o pagamento de laudêmio se houver a consolidação do domínio útil no fiduciário."

${ }^{218}$ A Lei no 11.076/2004 promoveu nova alteração à redação do parágrafo único do artigo 22 da lei do SFI, que, até a vigência da Lei $\mathrm{n}^{\circ} 11.481 / 2007$, era a seguinte: “A alienação fiduciária poderá ser contrata por pessoa física ou jurídica, não sendo privativa das entidades que operam no SFI, podendo ter como objeto bens enfitêuticos, hipótese em que será exigível o pagamento do laudêmio, se houver a consolidação do domínio útil do fiduciário."

${ }^{219}$ CHALHUB, op. cit., p. 232.
} 
transmite a outrem (enfiteuta ou foreiro) o domínio útil do imóvel, que deverá pagar ao senhorio direto, uma pensão, ou foro anual, certo e invariável (artigo $678^{220}$ ).

Com o advento da nova redação conferida ao inciso I do $\S 1^{\circ}$ do artigo 22 da lei do SFI, o credor-fiduciário, ao ser consolidado no domínio útil da coisa, deverá pagar o laudêmio ao senhorio direto, observadas as regras previstas do artigo 686 do Código Civil de $1916 .{ }^{221}$

Em relação à possibilidade de a alienação fiduciária ter como objeto a propriedade superficiária prevista no artigo 1.369 do Código Civil ${ }^{222}$, Melhim Chalhub menciona o Enunciado n $321^{223}$ da IV Jornada de Direito Civil promovida pelo Conselho da Justiça Federal em 2006, o qual esclarece que a bifurcação do direito de propriedade decorrente da concessão do direito de superfície resulta na constituição de dois patrimônios distintos, incomunicáveis: (i) o terreno, com os direitos e obrigações a ele vinculados, cujo titular é o proprietário do terreno; e (ii) a construção ou plantação, cujo titular é o concessionário da superfície.

Dada a incomunicabilidade entre os direitos e obrigações concernentes à superfície e à construção ou à plantação, o proprietário da superfície poderá indicá-la como garantia em eventual contrato de alienação fiduciária.

Feitas tais considerações sobre o contrato de alienação fiduciária de bem imóvel e o seu objeto, é possível responder à indagação sobre a possiblidade ou não de sucessivas propriedades fiduciárias sobre o mesmo bem imóvel, tal como ocorre com a hipoteca, na forma do artigo 1.476 do Código Civil ${ }^{224}$.

\footnotetext{
${ }^{220}$ BRASIL. Código Civil de 1916, Art. 678. Dá-se a enfiteuse, aforamento, ou emprazamento, quando por ato entre vivos, ou de última vontade, o proprietário atribui à outro o domínio útil do imóvel, pagando a pessoa, que o adquire, e assim se constitui enfiteuta, ao senhorio direto uma pensão, ou foro, anual, certo e invariável.

${ }^{221}$ BRASIL. Código Civil de 1916, Art. 686. Sempre que se realizar a transferência do domínio útil, por venda ou doação em pagamento, o senhorio direto, que não usar da opção, terá direito de receber do alienante o laudêmio, que será de dois e meio por cento sobre o preço da alienação, se outro não se tiver fixado no título de aforamento.

${ }^{222}$ BRASIL. Código Civil. Art. 1.369. O proprietário pode conceder a outrem o direito de construir ou de plantar em seu terreno, por tempo determinado, mediante escritura pública devidamente registrada no Cartório de Registro de Imóveis. Ao comentar sobre este artigo, Caio Mário conceitua o direito de superfície como sendo um direito real sobre coisa alheia, se apresentando como um desdobramento da propriedade, o que, de certo modo, se coaduna com entendimento do Enunciado ${ }^{\circ} 321$ da IV Jornada de Direito Civil do Conselho da Justiça Federal. SILVA, Caio Mário Pereira da, op. cit., p. 209.

${ }^{223}$ Enunciado $\mathrm{n}^{\circ} 321$ (Art. 1.369): "Os direitos e obrigações vinculados ao terreno e, bem assim, aqueles vinculados à construção ou à plantação formam patrimônios distintos e incomunicáveis, respondendo cada um dos seus titulares exclusivamente por suas próprias dívidas e obrigações, ressalvadas as fiscais decorrentes do imóvel."

${ }^{224}$ BRASIL. Código Civil. Art. 1.476. O dono do imóvel hipotecado pode constituir outra hipoteca sobre ele, mediante novo título, em favor do mesmo ou de outro credor.
} 
Conforme visto, as partes celebram um contrato de alienação fiduciária, pelo qual estipulam que o devedor-fiduciante transmitirá a propriedade resolúvel de um bem imóvel de sua titularidade ao credor-fiduciário com o objetivo de garantir determinada obrigação (artigo 22 da Lei $n^{\circ}$ 9.514/97). O contrato de alienação fiduciário trata-se, pois, de mero título para constituição da propriedade fiduciária.

Mediante o registro do contrato de alienação fiduciária perante o competente Registro de Imóveis (modo de aquisição), a propriedade fiduciária será constituída. Como decorrência lógica, o credor-fiduciário passa a deter formalmente a propriedade resolúvel (limitada) e a posse indireta da coisa imóvel objeto do contrato e, em contrapartida, o devedor-fiduciário demite-se da propriedade sobre o bem, remanescendo para si tão-somente a posse indireta do imóvel, conforme estipula o artigo 23 da lei do SFI.

O domínio pleno somente será restituído ao devedor-fiduciante através do adimplemento integral da sua obrigação. Ao ele, devedor-fiduciante, cabe apenas um direito expectativo, qual seja, a restituição da coisa mediante o integral cumprimento da sua obrigação. Até lá, a propriedade resolúvel do bem imóvel permanecerá nas mãos do credor-fiduciário.

Nesse contexto, verifica-se que o devedor-fiduciante carece de condição essencial para constituir nova garantia, já que, para tanto, a detenção da plena propriedade é requisito essencial. O devedor-fiduciante sequer poderá constituir nova propriedade fiduciária sobre o mesmo imóvel para o credor-fiduciário detentor da sua propriedade resolúvel. Neste sentido, Melhim Chalhub e Afranio Dantzger consignam:

Não sendo mais titular da propriedade, o fiduciante não tem mais a faculdade de dispor do bem ou onerá-lo, mas, não obstante a clareza dessa concepção, vez por outra surge alguma dúvida no mercado, sob o aspecto registrário, sobre a possibilidade de o fiduciante, embora despojado da propriedade, aliená-la fiduciariamente em $2^{\circ}, 3^{\circ}$ e mais graus, por analogia ao art. 1.476, do Código Civil, que regula a hipoteca. A resposta a essa questão não comporta divagações e/ou conjecturas, pois, ao dispor que o registro do contrato de alienação fiduciária opera a transferência da propriedade do imóvel para o fiduciário, a lei não dá margem a outra interpretação a não ser a de que a partir desse ato de registro o fiduciante estará despojado da propriedade, e, portanto, impossibilitado juridicamente de transferir novamente o imóvel para 
quem quer que seja ou novamente onerá-lo, em qualquer grau, pois, repita-se, não é mais titular do imóvel. ${ }^{225}$

Portanto, diferentemente do que ocorre com a hipoteca, onde o devedor permanece como proprietário do imóvel em garantia, podendo dela dispor ou onerá-la novamente, na alienação fiduciária, há transmissão da propriedade ao credorfiduciário, razão pela a constituição de duas ou mais propriedades fiduciárias para garantir diversos créditos com o mesmo imóvel revela-se impossível. Afinal, O devedor não tem mais poder de dispor da coisa imóvel para pactuar nova alienação fiduciária.

\subsection{Forma}

A forma é a expressão da vontade e elemento do suporte fático para todo e qualquer negócio jurídico. É a emissão de uma declaração que exterioriza um conteúdo, uma vontade negocial, que pode ser feito de diversas maneiras: oral, gestos e escrita. As declarações de vontade, portanto, não estão sujeitas à uma forma específica por conta do princípio da liberdade da forma.

Segundo Pontes de Miranda ${ }^{226}$, em regra, a sanção de nulidade é o princípio geral, motivo pelo qual para que a infração da regra sobre forma especial não produza o efeito da nulidade, é necessário que a lei o diga expressamente.

De acordo como renomado autor, a forma especial é aquela que o sistema jurídico exige para determinado ato, ou quando se trata de determinada pessoa, ou coisa. Todavia, Pontes de Miranda ${ }^{227}$ ressalva que a forma especial, que é exigida por lei, não se confunde com a forma voluntária, que é aquela decorrente da vontade humana.

Para que o ato produza efeito, ou seja, tenha eficácia, é preciso que certas formalidades sejam atendidas. Por exemplo, para constituição de direito sobre determinado imóvel, é necessário o registro do título que lhe deu causa. Dessa forma, a forma especial não se confunde com as exigências que a lei estabelece para que determinado ato seja eficaz.

\footnotetext{
225 CHALHUB, Melhim Namem; e Afranio Carlos Camargo Dantzger, Alienação Fiduciária de Bens Imóveis em segundo grau?, disponível em http://www.anoreg.org.br/index.php?option=com_content\&view=article\&id=13561:imported_13551\&catid= 32:artigos\&Itemid=12. Último acesso: 6 Jan. 2013.

${ }^{226}$ MIRANDA, op. cit., p. 389-390.

${ }^{227}$ MIRANDA, op. cit., p. 394.
} 
No caso da alienação fiduciária de bem imóvel, o contrato poderá ser formalizado por escritura pública ou por instrumento particular, nos termos do seu artigo 38 da Lei $n^{\circ}$ 9.514/97:

Art. 38. Os atos e contratos referidos nesta Lei ou resultantes da sua aplicação, mesmo aqueles que visem à constituição, transferência, modificação ou renúncia de direitos reais sobre imóveis, poderão ser celebrados por escritura pública ou por instrumento particular com efeitos de escritura pública.

A possibilidade de constituição de propriedade fiduciária mediante o registro de instrumento particular configura exceção à regra prevista no artigo 108 do Código Civil $^{228}$ para constituição de garantia real sobre bem imóvel de valor superior a trinta vezes o maior salário mínimo vigente no Brasil. O objetivo desta medida é justamente baratear o custo para celebração do contrato de alienação fiduciária de coisa imóvel de modo a incentivar a sua ampla utilização pela sociedade.

Como o artigo 38 da lei do SFI não faz qualquer restrição quanto às modalidades de contrato que poderão ser celebrados por meio de instrumento particular, Melhim Chalhub ${ }^{229}$ entende que poderão ser celebrados por instrumento particular a compra e venda, a promessa de venda, a hipoteca, a caução de direitos aquisitivos, a cessão fiduciária, etc., quando estiverem relacionados à comercialização e à constituição da propriedade fiduciária prevista na lei do SFI. 9.514/97

Para mencionado autor, a alienação fiduciária poderá ser vinculada a diversos contratos típicos e atípicos, razão pela qual não seria conveniente a restrição dos contratos passíveis de vinculação ao crédito imobiliário resultante da lei do SFI, porquanto todas as operações a ele relacionadas, tais como o financiamento, a compra e venda e a alienação fiduciária em garantia, são vinculadas e interdependentes.

Em contraposição, Marcelo Terra ${ }^{230}$ entende que a alienação fiduciária de bem imóvel restringe-se às operações de caráter pecuniário, de modo que somente poderia ser utilizada para a compra e venda de imóvel ou permuta com torna ou reposição em dinheiro, ou de mútuo de dinheiro, seja ele destinado para a aquisição de imóvel, seja para a constituição de capital de giro ou a crédito direto ao consumidor.

${ }^{228}$ BRASIL. Código Civil. Art. 108. Não dispondo a lei em contrário, a escritura pública é essencial à validade dos negócios jurídicos que visem à constituição, transferência, modificação ou renúncia de direitos reais sobre imóveis de valor superior a trinta vezes o maior salário mínimo vigente no País.

${ }^{229}$ CHALHUB, op. cit., p. 234.

${ }^{230}$ TERRA, op. cit., p. 29-30. 
Os incisos I a VII o artigo 24 da Lei $\mathrm{n}^{\circ}$ 9.514/97 dispõe sobre os requisitos para formalização do contrato, determinando taxativamente as cláusulas essenciais que deverão constar no referido instrumento, quais sejam: (i) o valor principal da dívida; (ii) o prazo e as condições de reposição do empréstimo ou do crédito fiduciário; (iii) a taxa de juros e os encargos incidentes; (iv) a cláusula de constituição da propriedade fiduciária, com a descrição do imóvel objeto da alienação fiduciária e a indicação do título e modo de aquisição; (v) a cláusula assegurando ao fiduciante, enquanto adimplente, a livre utilização, por sua conta e risco, do imóvel objeto da alienação fiduciária; (vi) a indicação, para efeito de venda em público leilão, do valor do imóvel e dos critérios para a respectiva revisão; e (vii) a cláusula dispondo sobre os procedimentos de que trata o art. 27.

Para sua melhor análise das cláusulas obrigatórias do contrato de alienação fiduciária em garantia, deve-se levar em consideração a hipótese mais comum para sua formação: a operação de financiamento, de compra e venda e de contrato de alienação fiduciária em garantia.

Os itens (i) a (iv) acima correspondem aos incisos I a IV do artigo 24 da lei do SFI, visam atender à regra geral para celebração dos contratos das garantias reais tradicionais previstas nos incisos I a IV do artigo 1.424 do Código Civil ${ }^{231}$. Como bem salienta San Tiago Dantas ${ }^{232}$, ao comentar os requisitos essenciais para constituição do contrato das garantias tradicionais (penhor, hipoteca e anticrese), na hipótese de omissão de um desses quatro requisitos no contrato, a garantia real não valerá contra terceiros, não surgindo, pois, o direito real.

As partes da operação ora examinada deverão ser o vendedor, normalmente, o incorporador; o comprador; e a financiadora, em geral entidade financeira autorizada a atuar no SFI, inicialmente como credora e, posteriormente, como credorafiduciária por força da constituição da propriedade fiduciária mediante o registro do contrato de alienação fiduciária.

\footnotetext{
${ }^{231}$ BRASIL. Código Civil. Art. 1.424. Os contratos de penhor, anticrese ou hipoteca declararão, sob pena de não terem eficácia: I - o valor do crédito, sua estimação, ou valor máximo; II - o prazo fixado para pagamento; III - a taxa dos juros, se houver; IV - o bem dado em garantia com as suas especificações. ${ }^{232}$ DANTAS, op. cit., p. 389-390.
} 
A descrição do imóvel, se urbano, deverá ser interpretada em consonância com o artigo $2^{\circ}$ da Lei $n^{\circ} 7.433 / 85^{233}$, a qual estabelece que, caso já constem em registro a caracterização e descrição do imóvel, poderá ser dispensada a descrição do imóvel na escritura pública, devendo nela constar o número do registro ou matrícula, dentre outros elementos. ${ }^{234}$

A cláusula que assegura ao devedor-fiduciante, enquanto adimplente, a livre utilização, por sua conta e risco, do imóvel objeto da alienação fiduciária, objetiva transferir para ele o risco da guarda e conservação do imóvel e, simultaneamente, o protege contra eventual abuso de direito por parte do credor-fiduciário. Para Paulo Restiffe Netto e Paulo Sérgio Restiffe ${ }^{235}$, essa cláusula representa uma "amadurecida inversão" das responsabilidades do devedor-fiduciante, possuidor direto do bem em decorrência do disposto no parágrafo único do artigo 23 da lei do SFI, já que seria fatal à segurança do credor-fiduciário se este fosse obrigado a responder pelo risco do pleno proprietário.

No tocante à indicação, para efeito de venda em público leilão, do valor do imóvel e dos critérios para a respectiva revisão, Chalhub ${ }^{236}$ observa a desnecessidade de o valor atribuído ao imóvel coincidir com o preço da venda, apesar de usualmente ser esse o valor indicado, já que o valor do imóvel para fins de leilão deve correspondente ao seu valor de mercado. A fixação de tal valor é imprescindível, na medida em que ele representará o lance mínimo a ser ofertado no primeiro, na hipótese de a propriedade ser consolidada na pessoa do credor-fiduciária por força do inadimplemento do devedor-fiduciante.

O contrato de alienação fiduciária deverá conter cláusula que disponha sobre os procedimentos de que trata o artigo 27 da lei do SFI. Este dispositivo legal regula a realização de leilões extrajudiciais, que, obrigatoriamente, deverão ser realizados dentro do prazo de 30 dias a contar da consolidação da propriedade na pessoa do credor-fiduciária. O procedimento para realização dos leilões extrajudiciais será analisado adiante em tópico próprio.

\footnotetext{
${ }^{233}$ BRASIL. Lei $n^{\circ}$ 7.433/85. Art. 2º . Ficam dispensados, na escritura pública de imóveis urbanos, sua descrição e caracterização, desde que constem, estes elementos, da certidão do Cartório do Registro de Imóveis.

${ }^{234}$ TERRA, op. cit., p. 25.

${ }^{235}$ RESTIFFE NETO, op. cit., p. 79.

${ }^{236}$ CHALHUB, op. cit., p. 233-234.
} 


\section{CAPÍTULO 5 A PROPRIEDADE FIDUCIÁRIA}

\subsection{A natureza jurídica da propriedade fiduciária}

Conforme examinado, a propriedade fiduciária nasce do registro (modo de aquisição) do contrato de alienação fiduciária em garantia de bem imóvel (título de aquisição) perante o competente Cartório de Registro de Imóveis, nos termos do artigo 23 da Lei $n^{\circ}$ 9.514/97.

A propriedade fiduciária não se confunde com os direitos reais limitados de garantia tradicionais (penhor, hipoteca e anticrese) nem com a propriedade fiduciária originada nos negócios fiduciários, nos quais o fiduciante transfere a propriedade de determinado bem ao fiduciário para fins de administração ou de garantia, confiando que este último a restituirá quando verificado o cumprimento da obrigação.

Nas garantias reais tradicionais (penhor, hipoteca e anticrese), o credor detém direito real sobre coisa alheia, sem qualquer participação na coisa, mas, sim, um direito no valor que a coisa possa alcançar em eventual alienação. San Tiago Dantas ${ }^{237}$ explica que, para o titular de um direito real de garantia realizar os benefícios do seu direito, a coisa precisa ser convertida em preço e, sobre este preço, é que recairá o direito do titular, onde ele encontrará a sua satisfação.

O devedor responde pelas suas obrigações com o seu patrimônio: é ele a garantia real dos seus credores. Na hipótese de inadimplemento do devedor, surge para o credor o direito de cobrar a obrigação ou o dever jurídico secundário que nasce de um inadimplemento ou de um ato ilícito. Neste caso, o credor buscará a satisfação do seu crédito no patrimônio do devedor. ${ }^{238}$

Caso o patrimônio do devedor exceda o valor da dívida, os seus credores encontrarão a satisfação do seu direito. Contudo, há situações em que o devedor não dispõe de patrimônio suficiente para responder pelo seu débito, ou seja, o devedor é insolvente. Nesta hipótese, o patrimônio do devedor será rateado de modo a responder proporcionalmente ao crédito dos seus credores.

Todavia, alguns credores detêm privilégio sobre os demais - direito de preferência - e serão objeto do primeiro rateio do patrimônio, enquanto outros só aparecerem em segundo plano, para o rateio do saldo residual. Muitas vezes o patrimônio

${ }^{237}$ DANTAS, op. cit., p. 381.

${ }^{238}$ DANTAS, op. cit., p. 382. 
do devedor é insuficiente para responder por toda a dívida e os credores situados no segundo plano deixam de satisfazer seu crédito, ou sequer existe patrimônio para o pagamento do débito.

Dessa forma, visando a diminuir e a controlar este risco de não satisfação integral do crédito, nasce no direito a possibilidade de instituição de garantias: a garantia pessoal ou fidejussória e a garantia real.

$\mathrm{Na}$ garantia pessoal, os direitos do credor estendem-se ao patrimônio de uma terceira pessoal, cuja cobertura econômica inspira maior confiança ${ }^{239}$. O fiador ou o avalista colocam seu patrimônio ao lado do patrimônio do devedor para responder pelo cumprimento da obrigação assumida pelo último.

Por outro lado, na garantia real, o credor destaca do patrimônio do devedor uma coisa na sua individualidade e declara que o valor de sua eventual alienação será destinado para o pagamento da dívida. Nesse sentido, San Tiago Dantas preleciona com o seu contumaz brilhantismo:

Em vez de ter-se, como garantia o patrimônio do devedor, no estado em que se acha quando a execução se verificar, obtém-se, como garantia, uma coisa, vinculada esta ao crédito, e, pouco importa, daí por diante, o estado em que se venha encontrar o patrimônio do devedor, a coisa está ligada ao cumprimento daquela obrigação. Se o devedor perder toda a sua fortuna, inclusive a coisa que escolheu para responder pelo seu compromisso, isso em nada atinge a segurança, porque a coisa, saindo do patrimônio do devedor, terá ido para outro patrimônio, e onde quer que se encontre, poder-se-á transformá-la no seu valor, e com esse valor satisfazer o cumprimento da obrigação. A coisa está vinculada à obrigação, está sujeita a um vínculo e, por essa razão, já os romanos diziam-se tratar-se de res obligata. Na verdade, a obrigação recai sobre a pessoa, mas tão intimamente está a coisa ligada à satisfação dela, que se pode dizer res obligata, como se a coisa estivesse envolvida no próprio vínculo da obrigação.

Nos negócios fiduciários do tipo romano - fiducia cum amico ou fiducia cum creditore -, a propriedade transmitida pelo fiduciante ao fiduciário era plena, podendo o fiduciário usar, gozar e dispor da coisa a ele entregue. Como proprietário pleno, nos negócios fiduciários, o fiduciário podia alienar a coisa recebida do fiduciante. Nesta

${ }^{239}$ DANTAS, op. cit., p. 383. 
hipótese, o fiduciante restava ao fiduciante tão-somente pleitear indenização por perdas e danos, inexistindo qualquer medida que pudesse ser tomada contra o terceiro adquirente no sentido de reaver a propriedade da coisa alienada.

A severidade de tal garantia real era tamanha que a sociedade romana buscou outra forma de garantia: a pignus, pela o devedor entregava uma coisa ao credor, mas, ao invés de efetuar a transmissão da propriedade da coisa pela mancipatio, tal como na fidúcia, apenas concedia ao credor o direito de deter a coisa até o integral cumprimento da obrigação. Neste caso, como o credor não era proprietário do bem, ele não podia aliená-la. Essa modalidade de pignus era chamada de datio pignoris.

Posteriormente, por motivos de utilidade econômica, foi inserido no direito romano o instituto da conventio pignoris, pela qual o devedor dava a coisa em garantia, porém ela permanecia em suas mãos, e, caso a dívida não fosse quitada, o credor tomava a coisa, a fim de satisfazer o seu crédito. Por meio do interdito Serviano, tornou-se possível que o credor buscasse o bem dado em garantia pelo devedor inadimplente mesmo quando ele já estivesse nas mãos de terceiro.

Por meio da influência grega, surgiu no direito romano a figura da hipoteca. E, a partir dela, nasceram os institutos do penhor (datio pignoris) e da hipoteca (conventio pignoris) no direito moderno. No direito civil brasileiro, enquanto no penhor a garantia real recai sobre coisa móvel, cuja detenção é transmitida para o credor, na hipoteca, a garantia real tem como objeto coisa imóvel que permanece em poder do devedor.

A partir dessas breves considerações sobre os direitos reais de garantia tradicionais, verifica-se que os institutos do penhor, da hipoteca e da anticrese recaem sobre coisa alheia. Tratam-se, pois, de direito real limitado ${ }^{240}$, cujo objetivo é identificar e segregar determinada coisa componente do patrimônio do devedor para eventual execução e penhora e, por conseguinte, a satisfação do crédito em aberto.

\footnotetext{
${ }^{240}$ Ao distinguir a propriedade plena e a limitada, San Tiago Dantas ensina: "Sempre que sobre um bem incide, além do direito de propriedade, um outro direito real, diz-se que a propriedade está limitada. É claro: o direito real, sendo um direito sobre a coisa e exercendo-se contemporaneamente à propriedade, destrói, numa certa medida, aquele exclusivismo, que corresponde à posição do proprietário. Pode o proprietário excluir todas as pessoas de qualquer ingerência sobre a coisa que lhe pertence, mas se uma dessas pessoas tem sobre ela uma servidão, por exemplo, tem de tolerá-la, e porque está obrigado a tolerá-la diz-se, então, que o seu direito de propriedade é limitado. Quando não incide nenhum direito real sobre coisa que está na propriedade de alguém, diz-se que esta propriedade é plena. Quando incide, paralelamente, o direito de propriedade e um outro direito real, diz-se que a propriedade é limitada, restrita, ou menos plena, e o titular do direito real, diz-se que tem um direito real na coisa alheia, um ius in re aliena." DANTAS, op. cit., p. 122 .
} 
Em contraposição, diferentemente dos direitos reais de garantia tradicionais e dos negócios fiduciários do tipo romano, na propriedade fiduciária, o devedor transfere a propriedade da coisa ao credor a título de garantia. Cuidando-se de bem imóvel, a lei do SFI determina que a propriedade transmitida ao credor-fiduciário tenha natureza resolúvel, assim, o domínio transferido não é pleno. E, apesar limitada, porquanto sujeita a uma condição resolutiva, a transmissão do domínio ao credor-fiduciário retira efetivamente o bem imóvel da esfera patrimonial do devedor-fiduciante até o integral cumprimento da obrigação.

Moreira Alves ${ }^{241}$ observa que alguns autores procuram distinguir na propriedade que se transmite no negócio fiduciário, a propriedade formal que pertenceria ao credor-fiduciário e a propriedade material que permaneceria com o devedor-fiduciante.

Ao que parece, essa teoria seria inspirada no trust do common law, que tem como fundamento básico a dupla propriedade sobre o mesmo bem: a propriedade formal ou nominal (legal property) e a propriedade substancial ou de fruição (equitable property).

Segundo Frederico Henrique Viegas de $\operatorname{Lima}^{242}$, a propriedade formal consiste na propriedade despojada de suas atribuições principais: a de usar e a de fruir. Somente restaria ao titular da propriedade formal, no caso, o credor-fiduciário, o direito de reivindicá-la e eventualmente de vê-la consolidada no seu patrimônio na hipótese de inadimplemento do devedor-fiduciante. Já a propriedade material, que cabe ao devedorfiduciante, diz respeito às faculdades, mesmo limitadas inerentes ao domínio.

Entretanto, dado o princípio da unicidade e indivisibilidade da propriedade em nosso direito ${ }^{243}$ e da incindibilidade do direito subjetivo do proprietário, não é possível conceber a divisão da propriedade, razão pela qual o credor-fiduciário receberá uma propriedade pura e verdadeira. Neste sentido, Martorell ensina:

Yo lo mismo puede decirse de cualquier otro caso de transmisión fiduciaria. La titularidad transmitida debe ser verdadera propiedad, puesto que ha de surtir, al menos em potencia, los efectos de ésta. Y, por otra parte, en que lo sea reside la razón de los negocios fiduciarios, porque, desde el momento en que el derecho otorgado a la persona interpuesta fuese cualquier otro diferente del de propiedad, aunque tan amplio como

\footnotetext{
${ }^{241}$ ALVES, op. cit., p. 154-155.

${ }^{242}$ VIEGAS, op. cit., p. 62-63.

${ }^{243}$ Caio Mário da Silva Pereira ensina que o direito de propriedade em si mesmo é uno. A condição normal da propriedade é a sua plenitude, ao passo que a limitação, como toda restrição ao gozo ou exercício dos direitos, é excepcional. PEREIRA, op. cit., p. 76.
} 
se quiera, es evidente que desaparecería la base fiduciaria del negocio, quedando como quedarían, en manos del transmitente propietario, las acciones reivindicatoria y negatoria $\mathrm{y}$, en general, todas inherentes al dominus. Mediante ellas tendría aquél en su mano la suerte de los actos de disposición torcidamente llevados a cabo contra su voluntad de dueño, expresada en el contrato otorgado con aquel a quien enajenó tal derecho. ${ }^{244}$

Embora o credor-fiduciário receba uma propriedade pura e verdadeira da coisa dada em garantia, esta propriedade não será considerada plena enquanto vigorar o contrato de alienação fiduciária em garantia que a instituiu. O domínio pleno é assim considerado quando o seu titular detém o direito real de uso, gozo e disposição sobre a coisa, com poderes de recuperação do bem de qualquer sujeito que, injustamente, o detenha ou possua, nos termos do artigo 1.228 do Código Civil.

$\mathrm{O}$ artigo 1.231 do Código Civil apresenta dois atributos da propriedade: o caráter absoluto e o caráter exclusivo. O caráter absoluto, segundo Aderbal da cunha Gonçalves ${ }^{245}$, refere-se à faculdade que o seu titular tem de exercer o mais amplo poder jurídico sobre a coisa, a plena in re potestas, gozá-la da forma que melhor lhe convier, transformando-a, abandonando-a, ou, até, destruindo-a, se assim lhe aprouver.

Washington de Barros Monteiro e Carlos Alberto Dabus Maluf ${ }^{246}$ salientam que o caráter absoluto da propriedade está sujeito a limitações, "impostas no interesse público ou pela coexistência do direito de propriedade dos demais indivíduos."

Em relação ao atributo da exclusividade do direito real de propriedade, Washington de Barros Monteiro e Carlos Alberto Dabus Maluf ${ }^{247}$ ensinam que a coisa não pode pertencer com exclusividade e simultaneamente a duas ou mais pessoas. Pelo direito exclusivo sobre a coisa, o proprietário pode excluir da coisa a ação de terceiros estranhos a ela. Consigne-se que a exclusividade comporta alterações, sendo possível que duas ou mais pessoas sejam coproprietárias de determinado imóvel, configurando o condomínio voluntário de coisa indivisa.

A terceira característica da propriedade diz respeito à sua perpetuidade, pela qual o direito de propriedade subsiste como real independentemente da

\footnotetext{
${ }^{244}$ MARTORELL, op. cit., p. 174-175.

${ }^{245}$ GONÇALVES, op. cit., p. 47.

${ }^{246}$ MONTEIRO, op. cit., p. 86.

${ }^{247}$ MONTEIRO, loc. cit.
} 
sua transmissão. Aderbal da Cunha Gonçalves ${ }^{248}$, com apoio em Barassi, assinala que a perpetuidade não é uma faculdade ligada à essência da propriedade, mas, sim, à sua natureza. Dessa forma, nada impede que a propriedade, apesar de ser perpétua por natureza, pode tornar-se temporária.

Segundo Moreira Alves ${ }^{249}$, pelo princípio da elasticidade da propriedade, este direito real, ao sofrer a ação de pressão exterior tem suas faculdades jurídicas reduzidas, mas, assim que o elemento compressor cessa, o domínio passa a ter a amplitude originária, restabelecendo a integralidade de todas as suas faculdades.

No caso da propriedade fiduciária é a lei que comprime o domínio conferido ao credor-fiduciário: enquanto o contrato de alienação fiduciária em garantia estiver em vigor, o credor-fiduciário será titular de um domínio restrito, limitado, que é a propriedade fiduciária. Porém, assim que o contrato se extinguir, seja pelo integral cumprimento da obrigação pelo devedor-fiduciante, seja pela consolidação da plena propriedade na pessoa do credor-fiduciário em razão do inadimplemento do devedorfiduciante, o escopo da garantia pelo qual a lei limitada a propriedade do credor-fiduciário desaparece por completo.

No que se refere à resolubilidade da propriedade fiduciária, verificase que essa característica também acaba por limitar o caráter absoluto ${ }^{250}$ do domínio do credor-fiduciário sobre a coisa dada em garantia. Ressalve-se que, apesar de o artigo 33 da Lei $\mathrm{n}^{\circ}$ 9.514/97 estabelecer a incidência, no que couber, das regras da propriedade resolúvel previstas nos artigos 1.359 e 1.360 do Código Civil, as figuras da propriedade resolúvel e da propriedade fiduciária não se confundem.

Do exame do artigo 33 da lei do SFI verifica-se que as figuras da propriedade fiduciária e da propriedade resolúvel não se confundem, já que o legislador adotou a expressão "no que couber" para as hipóteses em que as regras da propriedade resolúvel serão aplicadas na propriedade fiduciária. Caso contrário, aponta Frederico Henrique Viegas de Lima ${ }^{251}$, "a Lei seria equiparativa, dotando a propriedade fiduciária de todos os signos inerentes à propriedade resolúvel."

\footnotetext{
${ }^{248}$ GONÇALVES, op. cit., p. 64-65.

${ }^{249}$ ALVES, op. cit., p. 165-166.

${ }^{250}$ Neste sentido, Aderbal da Cunha Gonçalves assinala que "o caráter absoluto, hoje, em vez de referir-se à senhoria plena sobre a cousa, radicando-se, portanto, no próprio conteúdo da propriedade, assume, no dizer de Barassi, a expressão fisionômica da relação jurídica e se manifesta através da relação jurídica de valer erga omnes, em oposição "aquel'outra categoria de relações jurídica relativas, de onde derivam os direitos de crédito.” GONÇALVES, op. cit., p. 44.

${ }^{251}$ VIEGAS, op. cit., p. 69.
} 
San Tiago Dantas ${ }^{252}$ conceitua a propriedade resolúvel como "aquela submetida a termo ou condição resolutivos." Como exemplo de propriedade resolúvel, renomado autor cita o pacto de retrovenda e o fideicomisso.

No seu esboço do Código Civil, Teixeira de Freitas ${ }^{253}$ explica que o domínio imperfeito é o "direito real resolúvel, ou fiduciário, de uma só pessoa sobre uma coisa própria, móvel ou imóvel; ou o reservado pelo dono perfeito de uma coisa, que aliena somente seu domínio útil.”

Para Aderbal da Cunha Gonçalves ${ }^{254}$, a propriedade resolúvel existirá "toda vez que haja a possibilidade de uma predeterminação de revogabilidade, independente da vontade de seu atual titular. Ou quando adquirida em virtude de um título sujeito à resolução."

Washington de Barros Monteiro e Carlos Alberto Dabus Maluf ${ }^{255}$ buscam em Clóvis Beviláqua a definição de propriedade resolúvel, ensinando que é "aquela eu no próprio título de sua constituição encerra o princípio que a tem de extinguir, realizada a condição resolutória, ou vindo o termo extintivo, seja por força da declaração de vontade, seja por determinação da lei."

Com base nas definições de propriedade resolúvel acima, depreende-se que a causa da extinção da propriedade é fruto da vontade das partes, que determinam a ocorrência da condição ou termo, que extinguirá esta modalidade especial de domínio.

Constituída a propriedade resolúvel, o proprietário passará a figurar como proprietário pleno, embora seu direito seja limitado por determinado período de tempo pré-estabelecido em contrato. Nesse contexto, o proprietário resolúvel poderá dispor do seu direito e, ainda, constituir garantia real sobre ele. Serpa Lopes ${ }^{256}$ ensina:

Embora resolúvel, enquanto o evento não se produz, o titular de uma propriedade assim condicionada exerce os seus direitos em toda sua plenitude, como se a aludida cláusula não existisse. A outra parte, colocada em situação condicional, permanece numa situação restrita de pura expectativa, embora outros pretendam já existente um direito eventual. De qualquer modo, antes da superveniência do evento, o titular

\footnotetext{
${ }^{252}$ DANTAS, op. cit., p. 122.

${ }^{253}$ FREITAS, Teixeira de. Código Civil (esboço). Vol. IV. Ministério da Justiça e Negócios Interiores, Brasil, 1952, p. 1.177 e 1.232.

${ }^{254}$ GONÇALVES, op. cit., p. 67-68.

${ }^{255}$ MONTEIRO, op. cit., p. 286.

${ }^{256}$ LOPES, op. cit., p. 319.
} 
futuro de uma relação jurídica subordinada a uma condição resolutiva não tem nenhum direito adquirido.

Em relação à propriedade fiduciária, verifica-se que a condição resolutiva deriva da lei e não da vontade das partes, tal como ocorre na propriedade resolúvel. É o artigo 23 da lei do SFI que estabelece o caráter resolúvel da propriedade fiduciária e não a vontade das partes.

Além disso, a extinção da propriedade fiduciária imobiliária decorre expressamente da lei do SFI e não do pacto celebrado entre as partes, como ocorre na propriedade resolúvel. No âmbito da Lei $\mathrm{n}^{\circ}$ 9.514/97, o credor-fiduciário somente pode transferir o seu domínio se ceder ao adquirente o crédito cuja satisfação a propriedade fiduciária garante.

Do exposto, constata-se que a propriedade fiduciária não se enquadra em nenhum dos institutos existentes em nosso direito das coisas, não obstante o dato de se tratar de garantia real, na medida em que é destinada à garantia de cumprimento de obrigação. Conforme analisado, a propriedade fiduciária não possui as características dos direitos reais de garantia tradicionais (penhor, hipoteca e anticrese) nem dos negócios fiduciários, tratando-se, pois de um novo direito real de garantia imobiliária, apesar de possuir características com alguns institutos afins.

\subsection{A indivisibilidade da propriedade fiduciária}

A indivisibilidade é um dos efeitos da garantia real. Cuidando-se a propriedade fiduciária de uma garantia real, ela não é indivisível por natureza, mas por força da lei, a fim de assegurar o integral cumprimento da obrigação.

Parta Caio Mário da Silva Pereira ${ }^{257}$, num primeiro sentido, ela implica na sua adesão ao bem por inteiro e em cada uma de suas partes. Assim, enquanto vigorar a garantia, a coisa não pode se eximir do ônus, sob alegação de excesso em garantia, nem se admite a alienação parcial da coisa, sem a anuência do credor. Num segundo sentido, a indivisibilidade representa a sobrevivência integral da garantia, "em caso de pagamento parcial da obrigação assegurada, ainda que compreenda vários bens (art. 1.421)."

${ }^{257}$ PEREIRA, op. cit., p. 281. 
San Tiago Dantas ${ }^{258}$ também aponta a indivisibilidade como uma das características dos direitos reais de garantia, afirmando que esta se mantém inalterada, "mesmo quando a dívida já foi amortizada, salvo convenção em contrário."

A respeito de referido efeito da garantia real, José Serpa Santa Maria $^{259}$ explica que, ainda que a solução da obrigação seja parcial, registrando um reduzido saldo de débito, a garantia ainda sobrevive. Continua o autor a prelecionar que pouco importa que o devedor, proprietário de imóvel, tenha satisfeito cerca de $80 \%$ da sua dívida, porquanto a garantia subsistirá sempre em toda sua plenitude, ainda que ela recaia sobre diversos bens.

\subsection{O desdobramento da posse e suas consequências}

Além da constituição da propriedade fiduciária imobiliária, o parágrafo único do artigo 23 da lei do $\mathrm{SFI}^{260}$ prevê o desdobramento da posse da coisa dada em garantia mediante o registro do contrato de alienação fiduciária perante o Registro de Imóveis competente. Trata-se, pois, de um duplo efeito do ato registral do contato de alienação fiduciária em garantia de coisa imóvel.

Segundo Marcelo Terra ${ }^{261}$, “a classificação jurídica entre posse direta e posse indireta se dá pela distância do possuidor em relação ao imóvel possuído". Assim, o devedor-fiduciante, que é fisicamente mais próximo da coisa e a detém materialmente, é o seu possuidor direto, enquanto o credor-fiduciário é possuidor indireto, uma vez que concedeu a posse a terceiro.

Enquanto o devedor-fiduciante permanece com a posse direta do bem imóvel, o credor-fiduciário tem a posse indireta do imóvel dado em garantia. Segundo Frederico Henrique Viegas de Lima ${ }^{262}$, o desdobramento da posse na alienação fiduciária de coisa imóvel, por imperativo legal, é possível por conta do conceito de graduação vertical da posse previsto no artigo 1.197 do Código Civil. Essa posse tem caráter transitório, porquanto depende da propriedade fiduciária, que é um direito real de garantia temporal.

\footnotetext{
${ }^{258}$ DANTAS, op. cit., p. 389.

${ }^{259}$ SANTA MARIA, José Serpa de, Curso de direito civil, v. VII: direitos reais limitados, Rio de Janeiro: Freitas Bastos, 1998, p. 250.

${ }^{260}$ BRASIL. Lei $n^{\circ}$ 9.514/97. Art. 23. Parágrafo único. Com a constituição da propriedade fiduciária, dá-se o desdobramento da posse, tornando-se o fiduciante possuidor direto e o fiduciário possuidor indireto da coisa imóvel.

${ }^{261}$ TERRA, op. cit., p. 35.

${ }^{262}$ VIEGAS, op. cit., p. 71.
} 
Ao devedor-fiduciante é assegurado o uso e gozo do imóvel, exercendo todos os direitos inerentes ao legítimo possuidor, enquanto estiver adimplente, conforme estabelece o artigo $24, \mathrm{~V}$, da lei do SFI.

Por outro lado, na hipótese de inadimplemento, a posse indireta do credor-fiduciário prevalecerá sobre a posse direta do devedor-fiduciário, na medida em que está última se dará de modo injustificado - cuida-se da chamada posse injusta. Frente ao esbulho possessório praticado pelo devedor-fiduciante, o credor-fiduciário ou até mesmo terceiro que tenha adquirido o imóvel em leilão público são autorizados a ingressar com ação de reintegração de posse contra o devedor-fiduciante que injustamente possui a coisa, a fim de serem reintegrados na posse.

Constata-se que a pretensão possessória do credor-fiduciário situa-se em dois planos distintos: o primeiro quando o devedor-fiduciante é adimplente e paga integralmente a sua dívida e o segundo na hipótese de inadimplemento do devedorfiduciante, hipótese em que restará configurado o esbulho possessório.

Assim, quando o devedor-fiduciante cumprir integralmente a sua obrigação e a consequente restituição da propriedade ao seu patrimônio, o credorfiduciário, possuidor indireto e proprietário fiduciário da coisa imóvel dada em garantia, sequer terá tido a oportunidade de usar e fruir dos seus frutos.

Ressalve-se que o artigo 30 da Lei $\mathrm{n}^{\circ}$ 9.514/97 apenas permite o ajuizamento da ação de reintegração de posse pelo credor-fiduciário ou pelo eventual sucessor após a consolidação da propriedade. A inexecução do contrato de alienação fiduciária se prova mediante certidão expedida pelo Oficial do Registro de Imóvel que tiver promovido os procedimentos de intimação para purgação da mora.

Proposta a ação de reintegração de posse, o artigo 30 da lei do SFI também estabelece que ela "será concedida liminarmente, para desocupação em sessenta dias, desde que comprovada, na forma do art. 26, a consolidação da propriedade em seu nome." Portanto, deverá o credor-fiduciário ou seu sucessor apresentar elementos consistentes para prova documental do seu pedido e para identificação precisa do imóvel objeto da ação possessória, na medida em que tal procedimento admite apreciação imediata e depende de elementos objetivos que não deixem margem para qualquer dúvida ao magistrado acerca da concessão da liminar de reintegração de posse. 


\subsection{Direitos e obrigações do devedor-fiduciante e do credor-fiduciário}

Com o registro do contrato de alienação fiduciária de bem imóvel perante o competente Registro de Imóveis, a propriedade fiduciária é constituída e, por consequência, o devedor-fiduciante demite-se da propriedade, a qual é transmitida ao credor-fiduciário em caráter resolúvel. Ao devedor cabe tão-somente o direito expectativo de ser restituído na posse do imóvel depois de cumprida integralmente a sua obrigação de pagar a dívida.

Nesse sentido, Marcelo Terra ${ }^{263}$ observa a existência de três teorias que tratam da posição jurídica do devedor-fiduciante: (i) a primeira, que tem o devedorfiduciante como proprietário sob condição suspensiva; (ii) a segunda, que o considera mero titular de uma simples expectativa de direito; e (iii) a terceiro, que atribui ao devedorfiduciante um direito expectativo. De acordo com Terra, este último entendimento doutrinário é o correto, porquanto o devedor-fiduciante tem um mero direito expectativo de se tornar proprietário pleno do imóvel dado em garantia através do pagamento da dívida.

Essa pretensão restitutória do devedor-fiduciante está, portanto, subordinada a uma condição, que é o pagamento da dívida. Verificado o implemento da obrigação pelo devedor-fiduciante, a sua expectativa real consolida-se, nascendo daí o seu direito de ser restituído na plena propriedade do imóvel mediante a emissão, pelo credorfiduciário, do termo de quitação, que é o documento hábil para a reversão da propriedade para a pessoa do devedor-fiduciante.

Portanto, pode-se afirmar que a restituição do domínio pleno do imóvel dado em garantia mediante o integral pagamento da dívida e dos seus encargos configura o principal direito do devedor-fiduciante assegurado pelo artigo 25 da lei do SFI.

Caso o credor-fiduciário não emita o termo de quitação no prazo de trinta dias a contar da quitação da dívida pelo devedor-fiduciante, este poderá ajuizar ação de obrigação de fazer, a fim de obrigar o credor-fiduciário a cumprir a sua obrigação de emitir o termo de quitação, bem como pleitear o pagamento da multa correspondente a meio por cento por mês ou fração sobre o valor do contrato, nos termos do $\S 1^{\circ}$ do artigo 25 da lei do SFI.

Além do direito de reaquisição da plena propriedade da coisa imóvel dada em garantia, ao devedor-fiduciante também é assegurado o direito de utilizar o imóvel

${ }^{263}$ TERRA, op. citi., p. 39. 
objeto da alienação fiduciária livremente, por sua conta e risco, conforme o inciso IV do artigo 24 da Lei $n^{\circ} 9.514 / 97$, bem como o direito de exercer a posse direta do bem, usando e fruindo dos seus frutos, na forma do parágrafo único da Lei $n^{\circ}$ 9.514/97.

$\mathrm{Na}$ hipótese de inadimplemento, o $\S 3^{\circ}$ do artigo 26 da lei do SFI concede ao devedor-fiduciante o prazo de quinze dias para purgar a mora por meio do pagamento da prestação vencida e as que se vencerem até a data do pagamento, os juros convencionais, as penalidades e os demais encargos contratuais, os encargos legais, inclusive tributos, as contribuições condominiais imputáveis ao imóvel, além das despesas de cobrança e de intimação pelo Oficial do competente Registro de Imóveis.

Ao devedor-fiduciante também assegurado o direito de dar seu direito eventual ao imóvel em pagamento da dívida, desde que com a anuência do credorfiduciário, conforme estabelece o $\S 8^{\circ}$ do artigo 26 da lei do SFI.

Como a Lei ${ }^{\circ}$ 9.514/97 assegura o direito ao devedor-fiduciante de usar e fruir dos frutos advindos do imóvel, este poderá locá-lo a terceiros.

Por fim, na hipótese de a propriedade ser consolidada na pessoa do credor-fiduciário em razão do inadimplemento do devedor-fiduciante, a este último cabe o direito de receber a importância que sobejar ao valor da venda do imóvel em leilão público, conforme estabelece o $\S 4^{\circ}$ do artigo 27 da lei do SFI.

A principal obrigação do devedor-fiduciante é evidentemente pagar a dívida com todos os seus encargos. Além desta obrigação que é o cerne da alienação fiduciária de bem imóvel, a partir do momento em que é investido na posse direita do imóvel, o devedor-fiduciante passa a ser responsável pelo pagamento de todos os impostos taxas e contribuições que incidam sobre o imóvel, notadamente o IPTU e as contribuições condominiais, conforme preceitua o inciso IV do artigo 24. Esse dever perdura "até a data em que o fiduciário vier a ser imitido na posse", nos termos do $\S 8^{\circ}$ do artigo 27 da lei do SFI.

Consigne-se que a responsabilidade pelo pagamento do IPTU pelo devedor-fiduciante também encontra respaldo no Código Tributário Nacional nos seus artigos 32 e 34 . Ao passo que o artigo 32 preceitua que o IPTU "tem como fato gerador a propriedade, o domínio útil ou a posse do bem imóvel por natureza ou por acessão física, como definido na lei civil", o artigo 34 define como contribuinte o "possuidor a qualquer título".

O dever de pagar o IPTU somente cessa para o devedor-fiduciante na hipótese de a propriedade for consolidada na pessoa do credor-fiduciário e este for 
imitido na posse. Caso o credor-fiduciário pague o IPTU e eventuais despesas condominiais no período em que tal responsabilidade era do fiduciante, ele poderá pleitear o reembolso mediante o ajuizamento de ação própria.

O artigo 29 da Lei ${ }^{\circ}$ 9.514/97 também estabelece a obrigação do devedor-fiduciante de não transmitir os direitos de que seja titular sobre o imóvel objeto da alienação fiduciária em garantia sem a expressa anuência do credor-fiduciário.

Por fim, na hipótese de inadimplemento da obrigação de pagar a dívida e com consequente consolidação da propriedade na pessoa do credor-fiduciário, deverá o devedor-fiduciante desocupar o imóvel, devolvendo-o ao credor-fiduciário ou ao seu sucessor, sob pena de ser ajuizada ação possessória na forma do artigo 30 da Lei n] 9.514/97.

Em relação aos direitos do credor-fiduciário, depreende-se que este tem o direito a ser instituído na propriedade resolúvel do bem imóvel dado em garantia, nos termos dos artigos 22 e 23 da lei do SFI. Conforme examinado no decorrer deste trabalho, essa propriedade resolúvel se expirará com o pagamento integral da dívida e dos seus encargos pelo devedor-fiduciante, que, por seu turno, será restituído na propriedade plena do imóvel.

$\mathrm{Na}$ hipótese de inadimplemento do devedor-fiduciante, o artigo 26 da lei do SFI assegura ao credor-fiduciário o direito de ser consolidado na propriedade do bem imóvel dado em garantia.

Ao credor fiduciário também é assegurado o direito de alienação do bem imóvel a terceiros, justamente por ser seu proprietário, mesmo que em caráter resolúvel. Neste caso, o adquirente se sub-rogará nos direitos e obrigações assumidas pelo credor-fiduciário frente ao devedor-fiduciário, especialmente em relação à devolução da propriedade quando adimplida a obrigação.

As obrigações do credor-fiduciário referem-se essencialmente (i) ao dever de fornecer o termo de quitação ao devedor-fiduciante quando paga integralmente a dívida objeto da alienação fiduciária em garantia; e (ii) ao dever de restituir a propriedade.

O credor-fiduciário, como possuidor indireto do imóvel dado em garantia, é obrigado a respeitar a posse direta exercida pelo devedor-fiduciante, enquanto adimplente com suas obrigações. Além disso, cabe ao credor-fiduciário entregar ao devedor-fiduciante o saldo que sobejar em eventual venda do imóvel em leilão público, nos termos do $\S 7^{\circ}$ do artigo 27 . 


\subsection{A cessão da posição contratual}

Os artigos 28 e 29 da Lei $n^{\circ} 9.514 / 97$ preveem a possibilidade da cessão contratual tanto do devedor-fiduciante quando do credor-fiduciário, desde que observados alguns requisitos:

Art. 28. A cessão do crédito objeto da alienação fiduciária implicará a transferência, ao cessionário, de todos os direitos e obrigações inerentes à propriedade fiduciária em garantia.

Art. 29. O fiduciante, com anuência expressa do fiduciário, poderá transmitir os direitos de que seja titular sobre o imóvel objeto da alienação fiduciária em garantia, assumindo o adquirente as respectivas obrigações.

A cessão prevista na lei do SFI busca fomentar a circulação de créditos no mercado secundário de títulos de créditos, tendo como principal efeito a transmissão da posição contratual ocupada pelo devedor-fiduciante ou pelo credorfiduciário, também chamados de cedente, nos exatos termos que se encontrarem no momento da celebração do contrato de cessão.

\subsubsection{A cessão da posição do credor-fiduciário}

Nos termos do artigo 28 da lei do SFI acima transcrito, a cessão do crédito implicará a transferência ao cessionário de todos os direitos e obrigações no âmbito da alienação fiduciária em garantia de bem imóvel. Em observância ao princípio de que o acessório segue o principal implica também na transferência para o cessionário da garantia do objeto da alienação fiduciária, que é a propriedade fiduciária.

Mediante a cessão do crédito ocorrerá a substituição do credorfiduciário originário da relação contratual e, por ocasião da averbação do contrato de cessão perante o competente Registro de Imóveis, a propriedade fiduciária passará para o cessionário com o seu caráter resolúvel.

Além de efetivar a transferência da propriedade fiduciária ao cessionário, a averbação do contrato de cessão também o consolida na titularidade dos direitos e das obrigações inerentes a essa posição, especialmente o recebimento do crédito cedido e o dever de restituir a propriedade plena ao devedor-fiduciante com o pagamento 
integral da dívida, fornecendo o respectivo termo de quitação previsto no $\S 1^{\circ}$ do $\operatorname{artigo~} 25$ da lei do SFI. Nesse sentido, Melhim Chalhub ${ }^{264}$ assinala a relevância da averbação do contrato de cessão:

A averbação da cessão é indispensável, não só para validade contra terceiros, mas também perante o fiduciante, pois o fiduciário deve estar formalmente investido dos seus direitos para legitimar-se aos procedimentos de cobrança, constituição do fiduciante em mora, consolidação da propriedade em seu nome e implementação da ação de reintegração de posse.

Em regra, o cedente não responderá pela solvência do devedorfiduciante, exceto se o contrato de cessão estipular o contrário, nos termos do artigo 296 do Código Civil ${ }^{265}$.

O artigo 35 da lei do SFI também representa uma exceção à regra prevista no artigo 290 do Código Civil, na medida em que dispensa a obrigatoriedade da notificação do devedor-fiduciante nas cessões de crédito. Essa medida visa garantir maior celeridade aos negócios de cessão de crédito para fomentação do mercado secundário de créditos imobiliários.

Vale ressaltar que a cessão da posição do credor-fiduciário não implica na incidência do ITBI, porquanto não configura nenhuma das hipóteses previstas no artigo 156, II, da Constituição Federal, já que o que se transfere é a garantia real propriedade fiduciária.

\subsubsection{A cessão da posição do devedor-fiduciante}

O devedor fiduciante também pode ceder seus direitos sobre o imóvel objeto do contrato de alienação fiduciária em garantia, na forma do artigo 29 da lei do SFI. Neste caso, o devedor-fiduciante cede o seu direito expectativo à aquisição do domínio pleno da coisa imóvel transferida ao credor-fiduciário com escopo de garantia.

Diferentemente do que ocorre na cessão posição do credo-fiduciário, ao ceder a sua posição, o devedor-fiduciante deverá obter a expressa anuência do credor-

\footnotetext{
${ }^{264}$ CHALHUB, op. cit., p. 243.

${ }^{265}$ BRASIL. Código Civil. Art. 296: Salvo estipulação em contrário, o cedente não responde pela solvência do devedor.
} 
fiduciário, a fim de ser exonerado de suas obrigações. Caso contrário, os efeitos da cessão apenas surtirão efeitos entre o cedente e o cessionário.

Segundo Frederico Henrique Viegas de $\mathrm{Lima}^{266}$, a anuência do credor-fiduciário referida no artigo 29 da lei do SFI deve ser prestada no mesmo contrato de cessão celebrado entre o devedor-fiduciante e o cessionário, "uma vez que sempre é possível para as partes contratante livremente disporem sobre os objetivos da contratação, amoldando direitos e obrigações."

A cessão do devedor-fiduciante implica na sua substituição pelo cessionário, sub-rogado nos direitos e nas obrigações do devedor-fiduciante, notadamente o direito expectativo de ser tornar pleno proprietário do imóvel, devendo, para tanto, cumprir a sua obrigação de pagar a dívida objeto da garantia.

O contrato de cessão, com a anuência do credor-fiduciário, deverá ser levado a registro perante o competente Registro de Imóveis, juntamente com o comprovante de recolhimento do ITBI, pois trata-se de transmissão de direito real sobre imóvel, já que o cessionário receberá a plena propriedade do imóvel mediante o integral pagamento da dívida. Para Chalhub, o registro da cessão é de interesse de ambas as partes, credor-fiduciário e o novo devedor-fiduciante, pois

o cancelamento da propriedade fiduciária beneficiará aquele que figurar como fiduciante no Registro e, não havendo o registro da cessão, continuará figurando o antigo fiduciante; de outra parte, na hipótese de mora do devedor, não haverá discrepância entre o nome que figurar no requerimento de intimação, formulado pelo fiduciário, e o nome contrante no registro como titular dos direitos e obrigações do contrato.

${ }^{266}$ VIEGAS, op. cit., p. 139. 


\section{CAPÍTULO 6 A EXTINÇÃO DA PROPRIEDADE FIDUCIÁRIA}

A extinção da propriedade fiduciária se dá por duas formas distintas, sempre dependendo da atitude do devedor: a primeira, pelo pagamento da dívida pelo devedor-fiduciário, e a segunda mediante o inadimplemento da sua obrigação. A Lei ${ }^{\circ}$ 9.514/97 estabelece o procedimento a ser observado em ambos os casos, conforme será analisado a seguir.

\subsection{O adimplemento da obrigação principal}

A forma natural de extinção da propriedade fiduciária é o pagamento da dívida objeto da alienação fiduciária em garantia de bem imóvel pelo devedorfiduciante. $\mathrm{O}$ efeito principal da extinção é o cancelamento do registro da propriedade da propriedade fiduciária com o retorno do domínio pleno da coisa imóvel que fora alienada fiduciariamente. Com a extinção da propriedade fiduciária, também se extingue o desdobramento da posse em direta e indireta, retornando o devedor-fiduciante à sua posição de pleno possuidor do imóvel.

Ao quitar a dívida, o $\S 1^{\circ}$ do artigo 25 da lei do SFI estabelece que o credor-fiduciário deverá fornecer ao devedor-fiduciário o termo de quitação no prazo de dias subsequentes à liquidação. No caso de mora creditoris, o referido dispositivo legal estabelece a incidência de multa de meio por cento ao mês ou fração sobre o valor do contrato em favor do devedor-fiduciante.

A multa somente incidirá após o transcurso de trinta dias para entrega do termo de quitação, ou seja, a multa de meio por cento sobre o valor do contrato será a calcula pro rata die a partir do trigésimo primeiro dia após a liquidação da dívida pelo devedor-fiduciante, já que tem como base o intervalo de trinta dias.

Frederico Henrique Viegas de $\operatorname{Lima}^{267}$ aponta interessante questão relacionada ao alcance da expressão valor do contrato adotada no $\S 1^{\circ}$ do artigo 25 para fins de cálculo da multa pelo atraso no fornecimento do termo de quitação. A leitura do mencionado dispositivo leva ao equívoco de que a multa incidiria sobre o valor global da contratação. Assim, por exemplo, numa compra e venda de um imóvel com alienação fiduciária em que o preço fosse pago em parte com recursos próprios do devedor-

${ }^{267}$ VIEGAS, op. cit., p. 124. 
fiduciante e em parte com financiamento bancário, o valor do contrato para fins de apuração da multa refere-se ao valor do financiamento e não sobre a integralidade da negociação. Afinal, é o valor do financiamento que é garantido pela propriedade fiduciária. Portanto, é inadmissível a aplicação da multa prevista no $\S 1^{\circ}$ do artigo 25 da lei do SFI, sob pena de haver "enriquecimento injustificado" do devedor-fiduciante.

Com o termo de quitação em mãos e a autorização do cancelamento da propriedade fiduciária, o devedor-fiduciante deverá apresentá-los ao Oficial de Registro de Imóveis da situação do imóvel para que seja efetuada a averbação do cancelamento do registro da propriedade fiduciária, com fulcro no artigo 167, II, 2, da Lei n ${ }^{\circ} 6.015 / 73$.

Com base na técnica registrária, Viegas de Lima $^{268}$ entende que a terminologia "averbação" utilizada pelo legislador para cancelamento da propriedade fiduciária está incorreta. Para o aludido autor, a propriedade fiduciária não pode ser enquadrada nas categorias dos direitos reais de garantia tradicionais - hipoteca, penhor e anticrese -, já que o credor-fiduciário recebe a propriedade limitada e resolúvel para garantia da obrigação assumida pelo devedor-fiduciante. Neste diapasão, a norma do mencionado artigo 167, II, 2, da Lei $\mathrm{n}^{\circ}$ 6.015/73 não se aplica à propriedade fiduciária, porquanto direcionada às garantias reais tradicionais.

Assim, Viegas de Lima explica que o ato de registro seria o termo correto para o cancelamento da propriedade fiduciária e o consequente retorno da plena propriedade ao devedor-fiduciante, que, no fim das contas, representa a transferência da propriedade do credor-fiduciário ao devedor-fiduciante.

Por meio do cancelamento da propriedade fiduciária, há o retorno da plena propriedade ao devedor-fiduciante, sendo que os efeitos da extinção retroagem para a data da constituição da propriedade fiduciária. Todos os efeitos da propriedade fiduciária cessam a partir do seu cancelamento no Registro de Imóveis e a restituição da plena propriedade ao devedor-fiduciante é feita sem qualquer gravame.

\subsection{O inadimplemento da obrigação principal}

A forma natural de extinção da propriedade fiduciária é o pagamento da dívida objeto da alienação fiduciária em garantia de bem imóvel pelo devedorfiduciante. $\mathrm{O}$ efeito principal da extinção é o cancelamento do registro da propriedade da

${ }^{268}$ VIEGAS, op. cit., p. 125. 
propriedade fiduciária com o retorno do domínio pleno da coisa imóvel que fora alienada fiduciariamente. Com a extinção da propriedade fiduciária, também se extingue o desdobramento da posse em direta e indireta, retornando o devedor-fiduciante à sua posição de pleno possuidor do imóvel.

Ao quitar a dívida, o $\S 1^{\circ}$ do artigo 25 da lei do SFI estabelece que o credor-fiduciário deverá fornecer ao devedor-fiduciário o termo de quitação no prazo de dias subsequentes à liquidação. No caso de mora creditoris, o referido dispositivo legal estabelece a incidência de multa de meio por cento ao mês ou fração sobre o valor do contrato em favor do devedor-fiduciante.

A multa somente incidirá após o transcurso de trinta dias para entrega do termo de quitação, ou seja, a multa de meio por cento sobre o valor do contrato será a calcula pro rata die a partir do trigésimo primeiro dia após a liquidação da dívida pelo devedor-fiduciante, já que tem como base o intervalo de trinta dias.

Frederico Henrique Viegas de $\operatorname{Lima}^{269}$ aponta interessante questão relacionada ao alcance da expressão valor do contrato adotada no $\S 1^{\circ}$ do artigo 25 para fins de cálculo da multa pelo atraso no fornecimento do termo de quitação. A leitura do mencionado dispositivo leva ao equívoco de que a multa incidiria sobre o valor global da contratação. Assim, por exemplo, numa compra e venda de um imóvel com alienação fiduciária em que o preço fosse pago em parte com recursos próprios do devedorfiduciante e em parte com financiamento bancário, o valor do contrato para fins de apuração da multa refere-se ao valor do financiamento e não sobre a integralidade da negociação. Afinal, é o valor do financiamento que é garantido pela propriedade fiduciária. Portanto, é inadmissível a aplicação da multa prevista no $\S 1^{\circ}$ do artigo 25 da lei do SFI, sob pena de haver "enriquecimento injustificado" do devedor-fiduciante.

Com o termo de quitação em mãos e a autorização do cancelamento da propriedade fiduciária, o devedor-fiduciante deverá apresentá-los ao Oficial de Registro de Imóveis da situação do imóvel para que seja efetuada a averbação do cancelamento do registro da propriedade fiduciária, com fulcro no artigo 167, II, 2, da Lei nº 6.015/73.

Com base na técnica registrária, Viegas de $\operatorname{Lima}^{270}$ entende que a terminologia "averbação" utilizada pelo legislador para cancelamento da propriedade fiduciária está incorreta. Para o aludido autor, a propriedade fiduciária não pode ser enquadrada nas categorias dos direitos reais de garantia tradicionais - hipoteca, penhor e

${ }^{269}$ VIEGAS, op. cit., p. 124.

${ }^{270}$ VIEGAS, op. cit., p. 125. 
anticrese -, já que o credor-fiduciário recebe a propriedade limitada e resolúvel para garantia da obrigação assumida pelo devedor-fiduciante. Neste diapasão, a norma do mencionado artigo 167, II, 2, da Lei $\mathrm{n}^{\circ}$ 6.015/73 não se aplica à propriedade fiduciária, porquanto direcionada às garantias reais tradicionais.

Assim, Viegas de Lima explica que o ato de registro seria o termo correto para o cancelamento da propriedade fiduciária e o consequente retorno da plena propriedade ao devedor-fiduciante, que, no fim das contas, representa a transferência da propriedade do credor-fiduciário ao devedor-fiduciante.

Por meio do cancelamento da propriedade fiduciária, há o retorno da plena propriedade ao devedor-fiduciante, sendo que os efeitos da extinção retroagem para a data da constituição da propriedade fiduciária. Todos os efeitos da propriedade fiduciária cessam a partir do seu cancelamento no Registro de Imóveis e a restituição da plena propriedade ao devedor-fiduciante é feita sem qualquer gravame.

\subsection{O inadimplemento da obrigação principal}

Os consectários do inadimplemento da obrigação pelo devedorfiduciante estão previstos nos artigos 26 e 27 da lei do SFI e devem ser rigorosamente observados pelo credor-fiduciário, a fim de obter a satisfação do seu crédito.

$\mathrm{O}$ artigo 26 da Lei $\mathrm{n}^{\circ} 9.514 / 97^{271}$ estabelece que a dívida vencida e não paga, no todo ou em parte, e constituído em mora o fiduciante, a propriedade do imóvel objeto da alienação fiduciária em garantia consolidar-se-á na pessoa do credorfiduciário.

A fim de constituir o devedor-fiduciante em mora, o credorfiduciário deverá requerer a sua intimação pelo Oficial do competente Registro de Imóveis, para que pague, no prazo de quinze dias, a prestação vencida e as que se vencerem até a data do pagamento, os juros convencionais, as penalidades e os demais encargos contratuais, os encargos legais, inclusive tributos, as contribuições condominiais imputáveis ao imóvel, além das despesas de cobrança e de intimação ${ }^{272}$. Chalhub $^{273}$

271 BRASIL. Lei Federal no 9.514/96. Art. 26. Vencida e não paga, no todo ou em parte, a dívida e constituído em mora o fiduciante, consolidar-se-á, nos termos deste artigo, a propriedade do imóvel em nome do fiduciário.

${ }^{272}$ BRASIL. Lei $n^{\circ}$ 9.514/97. Art. 26, $\S 1^{\circ}$. Para os fins do disposto neste artigo, o fiduciante, ou seu representante legal ou procurador regularmente constituído, será intimado, a requerimento do fiduciário, pelo oficial do competente Registro de Imóveis, a satisfazer, no prazo de quinze dias, a prestação vencida e as que se vencerem até a data do pagamento, os juros convencionais, as penalidades e os demais encargos 
recomenda que o credor-fiduciário acoste ao requerimento com demonstrativo do débito, da mesma forma que ocorre no caso de execução (artigo 614 do Código de Processo Civil).

$\mathrm{O} \S 2^{\circ}$ do artigo 26 da lei do $\mathrm{SFI}^{274}$ prevê que o contrato definirá o prazo de carência, correspondente ao período entre o vencimento da obrigação não paga e a expedição da intimação, após o qual ela será expedida. Para Marcelo Terra ${ }^{275}$, a estipulação de prazo de carência no contrato representa a liberdade contratual das partes, o qual cessa com procedimento legal de intimação do devedor-fiduciante, que não pode ser alterado por vontade das partes. Essa é a mesma posição de Viegas de Lima ${ }^{276}$, que afirma que as partes devem convencionar sobre o prazo de carência para a intimação.

Destarte, havendo a previsão contratual acerca do prazo de carência de quinze dias, por exemplo, o credor-fiduciário deverá aguardar o decurso de mencionado prazo in albis, para, então, requerer a intimação do devedor-fiduciante através do Oficial do competente Registro de Imóveis.

Na hipótese de inexistir prazo de carência no contrato de alienação fiduciária, aplica-se a regra entabulada no artigo 397 do Código Civil ${ }^{277}$, que preceitua que o inadimplemento da obrigação constitui de pleno direito em mora o devedor. Assim, o credor-fiduciário poderá requerer a intimação do devedor-fiduciante tão logo esteja configurada a sua mora.

A regra do $\S 3^{\circ}$ do artigo 26 da lei do $\mathrm{SFI}^{278}$ estabelece que o devedor-fiduciante, ou o seu representante legal ou o seu procurador regularmente constituído, deverão ser intimados pessoalmente. Mediante solicitação do Oficial de Registro de Imóveis, essa intimação poderá ser realizada por Oficial de Registro de Títulos e Documentos da comarca da situação do imóvel ou do domicílio de quem deva recebê-la,

contratuais, os encargos legais, inclusive tributos, as contribuições condominiais imputáveis ao imóvel, além das despesas de cobrança e de intimação.

Ressalve-se que a lei não estipula que o requerimento do credor-fiduciário deva ser feito por escrito, autorizando, em tese, que tal pedido possa ser formulado de forma verbal. Contudo, compartilhamos o entendimento de Viegas de Lima de que é recomendável que o requerimento seja feito de forma escrita, para fins de comprovação do ato. LIMA, Frederico Henrique Viegas de, op. cit., p. 131.

${ }^{273}$ CHALHUB, op. cit., p. 251.

${ }^{274}$ BRASIL. Lei $n^{\circ} 9.514 / 97$. Art. 26, $§ 2^{\circ}$. O contrato definirá o prazo de carência após o qual será expedida a intimação.

${ }^{275}$ TERRA, op. cit., p. 43.

${ }^{276}$ VIEGAS, op. cit., p. 129.

277 BRASIL. Código Civil. Art. 397. O inadimplemento da obrigação, positiva e líquida, no seu termo, constitui de pleno direito em mora o devedor.

${ }^{278}$ BRASIL. Lei n ${ }^{\circ}$ 9.514/97. Art. 26, $\S 3^{\circ}$ A intimação far-se-á pessoalmente ao fiduciante, ou ao seu representante legal ou ao procurador regularmente constituído, podendo ser promovida, por solicitação do oficial do Registro de Imóveis, por oficial de Registro de Títulos e Documentos da comarca da situação do imóvel ou do domicílio de quem deva recebê-la, ou pelo correio, com aviso de recebimento. 
ou pelo correio, com aviso de recebimento. Caberá ao Oficial de Registro de Imóveis escolher qual modalidade de intimação será adotada.

Viegas de Lima $^{279}$ ressalva que, caso o devedor-fiduciante seja casado, a intimação também deverá ser endereçada ao seu cônjuge, salvo se o regime adotado pelo casal for o de separação absoluta de bens, na forma prevista no artigo 1.647 do Código $\mathrm{Civil}^{280}$, na medida em que o processo desencadeado poderá resultar na disposição do bem imóvel.

A intimação deverá ser dirigida ao endereço do devedor-fiduciante constante do contrato de alienação fiduciária ou ao endereço do imóvel dado em garantia. $\mathrm{Na}$ falta de tal informação no contrato, o credor-fiduciário poderá fornecê-la no momento em que solicitar a intimação do devedor-fiduciante perante o Registro de Imóveis.

Quando o devedor-fiduciante se encontrar em outro local, incerto e não sabido, o Oficial certificará o fato, devendo promover a intimação do devedorfiduciante por edital, publicado por três dias, pelo menos, em um dos jornais de maior circulação local ou noutro de comarca de fácil acesso, se o local não houver imprensa diária, conforme estatuí o $\S 4^{\circ}$ do artigo 26 da lei do $\mathrm{SFI}^{281}$. Como a lei não estipula qual é o prazo do edital, por analogia ao disposto no $\S 2^{\circ}$ do artigo 49 da Lei $n^{\circ} 6.766 / 79^{282}$, Marcelo Terra entende que o prazo do edital seria de dez dias, salvo se o contrato de alienação fiduciária estabelecer prazo mais dilatado.

Devidamente intimado, o devedor-fiduciante poderá purgar a mora, ocasião em que convalescerá o contrato de alienação fiduciária ${ }^{283}$. Nesse caso, deverá o devedor-fiduciante efetuar o pagamento diretamente no Cartório de Registro de Imóveis, o

${ }^{279}$ VIEGAS, op. cit., p. 130.

280 BRASIL. Código Civil. Art. 1.647. Ressalvado o disposto no art. 1.648, nenhum dos cônjuges pode, sem autorização do outro, exceto no regime da separação absoluta:

I - alienar ou gravar de ônus real os bens imóveis;

II - pleitear, como autor ou réu, acerca desses bens ou direitos;

III - prestar fiança ou aval;

IV - fazer doação, não sendo remuneratória, de bens comuns, ou dos que possam integrar futura meação.

${ }^{281}$ Lei $n^{\circ} 9.514 / 97$, art. 26, $\S 4^{\circ}$. Quando o fiduciante, ou seu representante legal ou procurador regularmente constituído se encontrar em outro local, incerto e não sabido, o oficial certificará o fato, cabendo, então, ao oficial do competente Registro de Imóveis promover a intimação por edital, publicado por três dias, pelo menos, em um dos jornais de maior circulação local ou noutro de comarca de fácil acesso, se no local não houver imprensa diária.

${ }^{282}$ BRASIL. Lei $n^{\circ} 6.766 / 79$. Art. $49, \S 2^{\circ} . \S 2^{\circ}$ Certificada a ocorrência dos fatos mencionados no parágrafo anterior, a intimação ou notificação será feita por edital na forma desta Lei, começando o prazo a correr 10 (dez) dias após a última publicação.

${ }^{283}$ BRASIL. Lei $n^{\circ} 9.514 / 97$. Art. 26, $§ 5^{\circ}$ Purgada a mora no Registro de Imóveis, convalescerá o contrato de alienação fiduciária. 
qual, por sua vez, entregará ao credor-fiduciário as importâncias recebidas, deduzidas as despesas de cobrança e intimação, consoante preceitua o $\S 6^{\circ}$ do artigo 26 da lei do $\mathrm{SFI}^{284}$.

Caso o pagamento seja feito por meio de cheque, é recomendável que o Oficial do Registro de Imóveis aguarde a sua compensação antes conferir a quitação do débito mediante a emissão de recibo.

Neste ponto, convém observar a imprecisão do $\S 1^{\circ}$ do artigo 26 da lei do SFI que prevê que o credor-fiduciário será consolidado na propriedade do imóvel quando "vencida e não paga, no todo ou em parte, a dívida e constituído em mora o fiduciante", porquanto este último, mesmo constituído em mora, poderá purgá-la, convalescendo, assim, o contrato de alienação fiduciária.

Portanto, a consolidação do credor-fiduciário na propriedade efetivamente se dá após o decurso do prazo legal de quinze dias para o devedor-fiduciante purgar a mora, com o esgotamento de todo o procedimento previsto nos $\S \S 1^{\circ}$ ao $6^{\circ}$ do artigo 26 da Lei $\mathrm{n}^{\circ}$ 9.514/97.

De todo modo, o $\S 7^{\circ}$ do artigo 26 da lei do SFI determina que, decorrido o prazo de quinze dias a contar da intimação do devedor-fiduciante sem que este purgasse a mora, o Oficial do Registro de Imóveis certificará esse fato, promoverá a averbação da consolidação da propriedade na pessoa do credor-fiduciário na matrícula do imóvel, condicionada ao pagamento do imposto de transmissão inter vivos - ITBI - e, se for o caso, do laudêmio.

Como a consolidação da propriedade na pessoa do credor-fiduciário configura uma das hipóteses previstas no inciso II do artigo 156 da Constituição Federal ${ }^{285}$ e objetiva a venda do imóvel no leilão extrajudicial, o ITBI é efetivamente devido, sendo a base de cálculo o valor do saldo devedor (vencido e vincendo) ou o valor venal, o que for maior $^{286}$.

A Lei $n^{\circ} 10.931 / 2004$ incluiu o $\S 8^{\circ}$ ao artigo 26 da Lei $n^{\circ} 9.514 / 97$ permitindo ao devedor-fiduciante dar em pagamento da dívida seu direito eventual ao imóvel, desde que com a anuência do credor-fiduciário, dispensando-se, assim, a realização dos leilões previstos no artigo 27.

${ }^{284}$ BRASIL. Lei no 9.514/97. Art. 26, § $6^{\circ}$ O oficial do Registro de Imóveis, nos três dias seguintes à purgação da mora, entregará ao fiduciário as importâncias recebidas, deduzidas as despesas de cobrança e de intimação.

285 BRASIL. Constituição Federal, Art. 156. Compete aos Municípios instituir impostos sobre: II transmissão "inter vivos", a qualquer título, por ato oneroso, de bens imóveis, por natureza ou acessão física, e de direitos reais sobre imóveis, exceto os de garantia, bem como cessão de direitos a sua aquisição.

286 TERRA, op. cit., p. 58. 
Não obstante o artigo 1.428 do Código Civil $^{287}$ vedar o pacto comissório, o seu parágrafo único ${ }^{288}$ autoriza o devedor dar em pagamento o objeto da garantia para extinguir a dívida. Trata-se de relevante introdução no ordenamento jurídico, ao passo que o artigo 765 do Código Civil de 1916, que, até então, regulava a matéria, não permitia tal operação. A possibilidade de o devedor dar em pagamento o bem objeto da garantia visa à célere satisfação do crédito do credor e está em perfeita harmonia com o disposto no $\S 8^{\circ}$ do artigo 26 da lei do SFI.

De qualquer forma, na alienação fiduciária em garantia, não se aplica a regra prevista no artigo 1.428 do Código Civil, porque, conforme explica Chalhub ${ }^{289}$, "é por força de lei, e não de um pacto, que se efetiva a apropriação de um bem pelo credor-fiduciário, e assim é dada a diversidade das estruturas jurídicas dessas distintas espécies de garantia real."

A regra insculpida no artigo 1.428 do Código Civil diz respeito tãosomente às espécies de garantias reais tradicionais sobre coisa alheia - hipoteca, penhor e anticrese -, nas quais a propriedade da coisa permanece com o devedor. Dado o princípio em que a norma proibitiva deve ser interpretada de forma restritiva, é inadmissível a aplicação de tal preceito à propriedade fiduciária em garantia.

Por meio da dação em pagamento, o credor-fiduciário passa a ser pleno proprietário da coisa imóvel, com todas as faculdades previstas no artigo 1.228 do Código Civil $^{290}$.

Caso não ocorra nenhuma das hipóteses previstas nos $\S \S 5^{\circ}$ (purgação da mora) ou $8^{\circ}$ (dação em pagamento) do artigo 26 da Lei n ${ }^{\circ}$ 9.514/97, o credorfiduciário será efetivamente consolidado na propriedade do imóvel. Viegas de Lima ${ }^{291}$ pondera que, uma vez registrada a consolidação da propriedade fiduciária na pessoa do credor-fiduciário, desaparece a propriedade resolúvel. Entretanto, esta nova propriedade adquirida pelo credor-fiduciário não é plena, porquanto ele é obrigado pelo artigo 27 da lei

${ }^{287}$ BRASIL. Código Civil. Art. 1.428. É nula a cláusula que autoriza o credor pignoratício, anticrético ou hipotecário a ficar com o objeto da garantia, se a dívida não for paga no vencimento.

${ }^{288}$ BRASIL. Código Civil. Art. 1.428, Parágrafo único. Após o vencimento, poderá o devedor dar a coisa em pagamento da dívida.

${ }^{289}$ CHALHUB, op. cit., p. 256.

${ }^{290}$ BRASIL. Código Civil. Art. 1.228. O proprietário tem a faculdade de usar, gozar e dispor da coisa, e o direito de reavê-la do poder de quem quer que injustamente a possua ou detenha.

${ }^{291}$ VIEGAS, op. cit., p. 134. 
do $\mathrm{SFI}^{292}$ a promover público leilão para alienação do imóvel no prazo de trinta dias contados da data do registro da consolidação. Observe-se a lição do renomado jurista:

Em virtude de o credor fiduciário não poder incorporar a nova propriedade em seu patrimônio, nem, tampouco, dela dispor como bem lhe aprouver, não podemos dispensar a esta espécie de propriedade o tratamento da propriedade plena. Em realidade, o que existe é uma limitação à mesma, no sentido da obrigatoriedade do credor fiduciário em aliená-lo em público leilão. Isto faz com que a propriedade que é transmitida ao credor fiduciário seja uma propriedade com escopo de garantia, deixando de existir a propriedade fiduciária nos moldes de propriedade resolúvel.

\subsubsection{A fase do leilão}

O artigo 27 da Lei ${ }^{\circ}$ 9.514/97 determina que o credor-fiduciário, ao ser consolidado na propriedade do imóvel, deverá promover público leilão para a alienação do imóvel no prazo de trinta dias a contar da data do registro da consolidação da propriedade em seu nome. No entanto, a lei não fixa qualquer sanção ao credor-fiduciário que não realizar o leilão no referido prazo.

Entretanto, na hipótese de o credor-fiduciário não realizar o público leilão no prazo legal, entendemos que o devedor-fiduciante poderá ajuizar ação de obrigação de fazer contra o credor-fiduciário, na medida em que a extinção da sua dívida está condicionada à realização do público leilão.

Quando o credor-fiduciário escolher pela realização do público leilão extrajudicial, este deverá ser levado a efeito por leiloeiro oficial devidamente inscrito no órgão público fiscalizador da atividade e visa conferir maior celeridade à recuperação do crédito do credor-fiduciário. Atualmente se tem notícia que alguns leiloeiros oficiais promovem leilões extrajudiciais de imóveis on line por meio de seus sites na Internet.

Viegas de Lima ${ }^{293}$ aponta que o credor-fiduciário poderá optar entre a realização do leilão com a intervenção do Poder Judiciário ou extrajudicialmente, mediante leilão privado, geralmente conduzido por leiloeira público. Segundo renomado

${ }^{292}$ BRASIL. Lei $n^{\circ}$ 9.514/97. Art. 27. Uma vez consolidada a propriedade em seu nome, o fiduciário, no prazo de trinta dias, contados da data do registro de que trata o $\S 7^{\circ}$ do artigo anterior, promoverá público leilão para a alienação do imóvel.

${ }^{293}$ VIEGAS, op. cit., p. 139. 
autor, a indicação de qual modalidade de leilão será utilizada pelo credor-fiduciário deverá estar prevista no contrato de alienação fiduciária em garantia.

Embora inexista previsão na lei do SFI acerca das regras para publicação de editais do público leilão, Marcelo Terra ${ }^{294}$ entende que tal medida é necessária, devendo ser adotada, por analogia, a regra do $\S 4^{\circ}$ do artigo 26 da lei do $\mathrm{SFI}^{295}$, que determina o procedimento a ser adotado para intimação do devedor-fiduciante, cujo paradeiro é desconhecido. Seguindo tal preceito, o edital do público leilão deverá ser publicado por três dias, pelo menos, em um dos jornais de maior circulação local ou noutro de comarca de fácil acesso, se o local não houver imprensa diária.

Também entendemos que não há qualquer óbice para adoção das regras para publicação do edital da alienação em hasta pública prevista nos artigos 686 e seguintes do Código de Processo Civil.

Em relação ao teor do edital, este deverá conter, pelo menos, as seguintes informações: (i) a completa descrição do imóvel, a situação e divisas, com remissão e aos registros da matrícula; (ii) indicação do ato praticado pelo competente Registro de Imóvel que consolidou a propriedade do imóvel na pessoa do credorfiduciário; (iii) o valor do imóvel constante do contrato de alienação fiduciária para venda em leilão extrajudicial; (iv) o valor da dívida, o qual, segundo o inciso I do $\S 3^{\circ}$ do artigo 27, consiste no "saldo devedor da operação de alienação fiduciária, na data do leilão, nele incluídos os juros convencionais, as penalidades e os demais encargos contratuais"; (v) referência ao fato de que, caso o maior lance ofertado seja inferior ao valor do imóvel, será realizado o segundo leilão, nos quinze dias seguintes, com indicação de dia e horários, conforme previsto no $\S 1^{\circ}$ do artigo 27 ; e (vi) nos termos do $\S 5^{\circ}$ do artigo 27 , a indicação de que, se no segundo leilão o maior lance oferecido não for igual ou superior ao valor da dívida, das despesas, dos prêmios de seguro, dos encargos legais, inclusive tributos, e das contribuições condominiais, considerar-se-á extinta a dívida, fato que acarretará em recíproca quitação entre o credor-fiduciário e o devedor-fiduciante.

Após a publicação do edital, será realizado o primeiro leilão, cujo referencial para efeitos de lance deverá ser obrigatoriamente o valor do imóvel previsto no contrato de alienação fiduciária em garantia. Tal medida visa proteger tanto o devedor-

${ }^{294}$ TERRA, op. cit., p. 45-46.

${ }^{295}$ BRASIL. Lei ${ }^{\circ}$ 9.514/97. Art. 26, $\S 4^{\circ}$. Quando o fiduciante, ou seu representante legal ou procurador regularmente constituído se encontrar em outro local, incerto e não sabido, o oficial certificará o fato, cabendo, então, ao oficial do competente Registro de Imóveis promover a intimação por edital, publicado por três dias, pelo menos, em um dos jornais de maior circulação local ou noutro de comarca de fácil acesso, se no local não houver imprensa diária. 
fiduciante quanto o credor-fiduciário de modo que o valor eventualmente oferecido pelo imóvel seja o mais próximo possível do seu valor de mercado.

Chalhub $^{296}$ afirma que, na prática do mercado e das incorporações imobiliárias e do financiamento imobiliário, nas operações que têm como objeto a compra e venda de edificações, o valor para lance mínimo do primeiro leilão geralmente adotado corresponde ao preço pelo qual foi contratada a compra e venda da unidade imobiliária, reajustável nas mesmas condições pactuadas para reajuste do financiamento.

Marcelo Terra ${ }^{297}$ aponta as duas hipóteses que poderá ocorrer no primeiro leilão, se o maior lance for:

a) superior ao valor do imóvel, o credor (fiduciário) está obrigado a aceitá-lo e a vender o imóvel ao licitante vencedor;

b) não havendo lance superior ao valor do imóvel, nem o comparecimento de qualquer licitante, será necessariamente realizado um segundo leilão, dentro de quinze dias do primeiro (§ 1, art. 27).

Caso o maior lance oferecido no primeiro leilão for inferior ao valor do imóvel, o $\S 1^{\circ}$ do artigo da lei do SFI determina que será realizado o segundo leilão nos quinze dias subsequente. Nesta hipótese, o $§ 2^{\circ}$ do artigo 27 da Lei $n^{\circ}$ 9.514/97 estabelece que o menor lance deverá ser igual ou superior da dívida, das despesas, dos prêmios de seguro, dos encargos legais, inclusive tributos, e das contribuições condominiais.

O inciso I do $\S 3^{\circ}$ do artigo 27 define que dívida é "o saldo devedor da operação da alienação fiduciária, na data do leilão, nele incluídos os juros convencionais, as penalidades e os demais encargos contratuais.” Já o inciso II do $\S 3^{\circ}$ do aludido dispositivo legal define despesas como "a soma das importâncias correspondentes aos encargos e custas de intimação e as necessárias à realização do público leilão, nesta compreendidas as relativas aos anúncios e à comissão do leiloeiro."

Como se vê, o parâmetro para realização do segundo leilão muda completamente em relação ao primeiro leilão, uma vez que naquele cessa a obrigatoriedade do lance mínimo ser equivalente ao valor do imóvel estipulado no contrato de alienação fiduciária, desaparecendo o direito do devedor de ter o imóvel arrematado por tal montante.

${ }^{296}$ CHALHUB, op. cit., p. 262-263.

${ }^{297}$ TERRA, op. cit., p. 46. 
$\mathrm{Na}$ hipótese de o lance ofertado no segundo leilão igualar ou ultrapassar o valor da dívida, das despesas, dos prêmios de seguros, dos encargos legais, inclusive tributos e das contribuições condominiais, o credor-fiduciário deverá (i) aceitar o lance oferecido; e (ii), nos cinco dias seguintes à venda do imóvel no leilão entregar ao devedor-fiduciante a importância que sobejar, considerando-se nela compreendido o valor da indenização de benfeitorias, depois de deduzidos os valores da dívida e das despesas e encargos que tratam os $\S \S 2^{\circ}$ e $3^{\circ}$.

Além disso, será expedida a carta de arrematação ao licitante vencedor, sendo que a forma de transmissão será a compra e venda e o modo de transmissão será o registro do título perante o competente Registro de Imóveis. O título poderá ser celebrado por instrumento público, por força do disposto no artigo 38 da Lei ${ }^{\circ}$ 9.514/97, o qual estabelece que os contrato resultantes da aplicação da lei, "mesmo aqueles que visem à constituição, transferência, modificação ou renúncia de direitos reais sobre imóveis", poderão ser convencionados de tal forma.

Por outro lado, caso o maior lance ofertado não igualar nem superar o valor da dívida, considerar-se-á extinta a dívida, sendo o devedor-fiduciante automaticamente exonerado da obrigação, desaparecendo, em contrapartida, o direito do credor-fiduciário de continuar a cobrança do saldo residual, nos termos do $\S 5^{\circ}$ do artigo 27 da Lei $n^{\circ}$ 9.514/97. Ademais, o credor-fiduciário, no prazo de cinco dias a contar da data do leilão, fornecerá ao devedor-fiduciante o termo de quitação da dívida, nos termos do $\S$ $6^{\circ}$ do artigo 27.

Marcelo Terra ${ }^{298}$ entende ser desnecessária a realização de um terceiro leilão na hipótese de não houver o comparecimento de qualquer licitante no segundo leilão ou se o menor lance oferecido não igualar o valor da dívida, porquanto a lei não determina a realização de novos leilões. Assim, o credor-fiduciário será consolidado no domínio pleno do imóvel, "podendo alienar o imóvel, se e quando quiser, independentemente do procedimento do leilão extrajudicial." Por fim, renomado autor recomenda que o título transmissivo da propriedade indique a realização (sem sucesso) dos dois leilões obrigatórios, preferencialmente acompanhado de certidão expedida pelo leiloeiro.

Por fim, Viegas de Lima $^{299}$ indica que, frustrados os dois leilões previstos na lei do SFI e sendo o imóvel em condomínio, prevalecerá o direito de

298 TERRA, op. cit., p. 47.

${ }^{299}$ VIEGAS, op. cit., p. 143. 
preferência do condômino em relação ao credor-fiduciário. Continua mencionado autor ensinando que "a preferência será exercida em igualdade e condições, pelos valores apurados, quer no leilão, quer naquele em que o credor-fiduciário deve realizar a liberação do devedor-fiduciante." 


\section{CAPÍTULO 7 QUESTÕES CONTROVERTIDAS}

\subsection{A discussão sobre a constitucionalidade do leilão extrajudicial}

A questão acerca da constitucionalidade do leilão extrajudicial até a presente data ainda é ponto controverso na doutrina e na jurisprudência.

Renomados doutrinadores entendem que o procedimento do leilão extrajudicial regulado pela lei do SFI seria inconstitucional, na medida em que tal medida desrespeitaria o princípio constitucional previsto na letra a do inciso XXXIV do artigo $5^{\circ}$ da Constituição Federal, que garante a todos o direito de petição aos Poderes Públicos para defesa de direitos ou ilegalidade ou abuso de poder.

Além disso, com fundamento no inciso XXXV do artigo $5^{\circ}$ da Constituição Federal, essa corrente doutrinária defende que o leilão extrajudicial feriria o princípio da indeclinabilidade da jurisdição, o qual estabelece que "a lei não excluirá da apreciação do Poder Judiciário lesão ou ameaça a direito."

Nesse sentido, cumpre destacar a valiosa lição de Manoel Justino Bezerra Filho $^{300}$ acerca da incompatibilidade dos mencionados dispositivos constitucionais e o leilão extrajudicial previsto da Lei $n^{\circ} 9.514 / 97$ :

Estes dois incisos [incisos XXXIV e XXXV do artigo $5^{\circ}$ da Constituição Federal] não podem sequer ser alterados por leis de natureza ordinária, ante o óbvio de que o direito garantido constitucionalmente não pode ser afastado por legislação ordinária. No entanto, não só por isto: - estes direitos, por se configurarem como cláusulas pétreas da Carta Magna, não poderiam ser suprimidos, mesmo que houvesse reforma da Constituição, a menos que a reforma partisse do poder constituinte originário, o que não era o caso do Congresso Nacional de 1997, ano da promulgação desta Lei 9.514/97. Com esta legislação, ocorreu o que, infelizmente, nestes nossos tempos omissos, cada vez mais se torna comum, ou seja, a desconsideração de normas pétreas da Constituição, avançando o legislador sobre direitos ante os quais deveria deter-se, e isso sob as mais diversas justificativas.

\footnotetext{
${ }^{300}$ BEZERRA FILHO, Manoel Justino. A execução extrajudicial do contrato de alienação fiduciária de bem imóvel: exame crítico da Lei 9.514, de 20.11.1997. Revista dos Tribunais - Papel, v. 93, n. 819, p. 65-76, jan. 2004, p. 70.
} 
No caso, como se sabe, o direito que quis preservar foi a garantia de recebimento do valor devido, em favor de construtoras, de bancos e agora neológicas "companhias de securitização", quintessência do capital meramente especulativo, que tantos males tem feito a este nosso sofrido País. Concorda-se com o argumento de que é necessário dirigir volumes significativos de poupança para o crédito imobiliário e com isto tentar, se não resolver, pelo menos tomar menos grave o problema da habitação no País; no entanto, e isto também é examinado abaixo, há de se manter respeito ao princípio da proporcionalidade, sob pena de se começar a duvidar até da pureza das intenções daqueles que patrocinaram a promulgação da lei.

Além dos dispositivos constitucionais mencionados por Manoel Justino Bezerra Filho também é possível incluir na relação os incisos LIV e LV do artigo $5^{\circ}$ da Constituição Federal, que impedem que alguém seja privado da liberdade ou de seus bens sem o devido processo legal e assegurando o contraditório e a ampla defesa.

Esse conjunto de princípios constitucionais indicados nos incisos XXXIV, XXXV, LIV e LV consolidam uma única base representada pelo princípio do devido processo legal (“due processo of law”), pelo qual eventual limitação a cognição do juiz deve ser considerada inconstitucional.

Nesse sentido, Adroaldo Furtado Fabrício ${ }^{301}$ assevera que a entrega da iniciativa e condução do procedimento do leilão extrajudicial ao credor-fiduciário, sem a intermediação do Poder Judiciário, "representa uma inaceitável regressão à autotutela." Para referido autor, o leilão extrajudicial demonstra uma "opção preferencial pela proteção ao capital, ao custo do princípio da indeclinabilidade da jurisdição."

Dentre os argumentos apresentados por Manoel Justino de Bezerra Filho para embasar sua posição está o acórdão proferido pelo Supremo Tribunal Federal por ocasião do julgamento do Recurso Extraordinário $\mathrm{n}^{\circ}$ 25.545-SP em julgamento ocorrido em 20.08.2002, o qual deixou de conhecer o recurso sob o fundamento que a decisão recorrida não trouxe declaração formal de inconstitucionalidade de tratado ou lei defesa. O mencionado acórdão ainda afirma que tal hipótese é “inconfundível com o reconhecimento de que forma legal anterior à Carta de 1988 não foi recebida, por

${ }^{301}$ FABRÍCIO, Adroaldo Furtado. A alienação fiduciária de imóveis segundo a Lei no 9.514/97. Revista da AJURIS, Porto Alegre, v. 26, n. 80, p. 354-376, dez. 2000, p. 368. 
incompatível” ${ }^{\text {302 }}$. Por conseguinte, essa decisão do Supremo Tribunal Federal resultou na prevalência do que fora decidido pelo Tribunal Regional Federal da $3^{\mathrm{a}}$ Região, nos seguintes termos:

A execução extrajudicial prevista no Dec-lei 70/66 não se amolda às garantias oriundas do devido processo legal, do juiz natural, do contraditório e da ampla defesa, constantes do Texto Constitucional em vigor, pois é o próprio credor quem realiza a excussão do bem, subtraindo o monopólio da jurisdição do Estado, quando deveria ser realizada somente perante um magistrado constitucionalmente investido na função jurisdicional, competente para o litígio e imparcial na decisão da causa.

Apesar dos sólidos argumentos para configuração da inconstitucionalidade do procedimento do leilão extrajudicial pela inobservância do princípio constitucional do devido processo legal, a jurisprudência do Supremo Tribunal Federal acabou por consolidar o entendimento acerca da constitucionalidade da consolidação da propriedade na pessoa do credor e o consequente leilão extrajudicial, conforme se verifica do acórdão prolatado por ocasião do julgamento do Recurso Extraordinário no 223.075-DF, relatado pelo Ministro Ilmar Galvão, o qual decidiu que os procedimentos extrajudiciais do Decreto-Lei $\mathrm{n}^{\circ}$ 70/66 seriam constitucionais, porquanto, "além de prever uma fase de controle judicial, antes da perda do imóvel pelo devedor (art. $36, \S 2^{\circ}$ ), não impede que eventual ilegalidade perpetrada no curso da venda do imóvel seja, de logo, reprimida pelos meios processuais próprios."

Seguindo o entendimento emanado pelo Supremo Tribunal Federal, a jurisprudência quase que de forma unânime passaram a entender que o procedimento do leilão extrajudicial seria constitucional, na medida em que estaria assegurado ao devedorfiduciante "o amparo jurisdicional para questionar o valor de prestações cobradas pelo credor", conforme foi decidido pelo Superior Tribunal de Justiça no EREsp nº 462.659, relatado pelo Ministro Ari Parglender.

No mesmo sentido é a opinião de Melhim Chalhub ${ }^{303}$, José Manoel de Arruda Alvim Netto ${ }^{304}$ e Marcelo Terra ${ }^{305}$, que afirmam que inexiste qualquer

\footnotetext{
${ }^{302}$ BRASIL. Supremo Tribunal Federal, Recurso Extraordinário $\mathrm{n}^{\circ}$ 25.545-SP, julgamento ocorrido em 20.08.2002.

${ }^{303}$ CHALHUB, op. cit., p. 331

304 ALVIM NETTO, José Manoel de Arruda. Alienação fiduciária de bem imóvel. O contexto da inserção do instituto (Parecer). In: Alienação fiduciária e direito do consumidor. São Paulo: Abecip, (s.d)., p. 23

${ }^{305}$ TERRA, Marcelo, op. cit., p. 53.
} 
incompatibilidade entre as normas relativas à propriedade resolúvel e ao leilão extrajudicial e as normas que asseguram o direito de ação, pois o controle jurisdicional do procedimento do leilão extrajudicial seria assegurado em dois momentos: (i) no início, com a intimação do devedor-fiduciante, que, por conseguinte, poderá impugnar as regularidade do procedimento em juízo; e (ii) a posteriori, com eventual questionamento em juízo sobre o valor da venda realizada em leilão.

Quando parecia que a matéria acerca da constitucionalidade do leilão extrajudicial estaria pacificada em nossos Tribunais, se tem notícia que durante a confecção desta dissertação, o Supremo Tribunal Federal iniciou o julgamento do Recurso Extraordinário no 556.520 e do Recurso Extraordinário nº 627.106, sendo que este último já tece repercussão geral conhecida. Até o depósito deste trabalho (janeiro de 2013), havia quatro votos pela incompatibilidade dos dispositivos do Decreto-Lei $n^{\circ} 70 / 66$, ao passo que outros dois ministros votaram pela inexistência de incompatibilidade das regras insculpidas no referido decreto-lei com a Constituição Federal, ressalvando o fato de que o Supremo Tribunal Federal tem jurisprudência pacífica sobre a matéria.

O Recurso Extraordinário no 556.520 é relatado pelo Ministro Marco Aurélio, quem já proferiu seu voto pela inconstitucionalidade das regras do Decreto-Lei ${ }^{\circ}$ 70/66 na parte viabilizadora da execução privada - segunda parte do artigo 29 e artigos 31 a 38 -, que, a seu ver, não foi recepcionada pela Constituição Federal de 1988, na medida em que contraria o princípio do devido processo legal.

Os mencionados recursos passaram a ser julgados conjuntamente, pois, antes de proferir seu voto, o Ministro Dias Toffoli assinalou que havia pedido vista dos autos do Recurso Extraordinário no 556.520, sob relatoria do Ministro Marco Aurélio.

Em agosto de 2011, o julgamento dos recursos foi suspenso em razão do pedido de vista formulado pelo Ministro Gilmar Mendes, que, segundo consta da notícia vinculada no site do Supremo Tribunal Federal em 18 de agosto de $2011^{306}$, afirmou estar "extremamente preocupado" com o deslinde do julgamento dos recursos, afirmando que “em países que respeitam ‘o estado de direito’ é muito comum a prática de execução nos moldes do Decreto-lei 70/66."

Não obstante a discussão acerca da constitucionalidade do procedimento do leilão extrajudicial previsto na Lei $n^{\circ} 9.514 / 97$, que, até então, parecia

\footnotetext{
${ }^{306}$ Disponível em: http://www.stf.jus.br/portal/cms/verNoticiaDetalhe.asp?idConteudo=186899\&caixaBusca=N. Último acesso: 6 Jan. 2013.
} 
superada, outro tópico tem merecido especial atenção dos doutrinadores: a constitucionalidade do $\S 2^{\circ}$ do artigo 27 da lei do SFI, que determina que no segundo leilão será aceito o maior lance oferecido, desde que igual ou superior da dívida, das despesas, dos prêmios de seguro, dos encargos legais, inclusive tributos, e das contribuições condominiais.

Nesse sentido, cumpre destacar a lição de Flávio Tartuce e de José Fernando Simão ${ }^{307}$, que, com apoio em Cristiano Chaves e Nelson Rosenvald, asseveram que $\S 2^{\circ}$ do artigo 27 da lei do SFI é inconstitucional, pois

o dispositivo ao prever que no segundo leilão a coisa seja vendida pelo maior lance oferecido e desde que esse lance cubra o valor do débito, possibilita que o devedor perca a coisa, bem como tudo o que foi pago, sem ter condições de discutir judicialmente o fato de ser privado da propriedade.

Com base no princípio da socialidade, renomados civilistas ponderam que o lance oferecido no lance do segundo leilão previsto no artigo $27, \S 2^{\circ}$, da lei do SFI não deve ser muito inferior ao valor do imóvel objeto da alienação fiduciária em garantia, sob pena de configuração da onerosidade excessiva do negócio jurídico que fundamenta a sua revisão, ou mesmo sua anulação, nos termos do artigo 157 do Código Civil.

Além disso, Tartuce e Simão afirmam que o $§ 2^{\circ}$ do artigo 27 da lei do SFI dá margem à eventual incentivo ao enriquecimento seu causa, porquanto terceiro licitante poderá adquiri o imóvel pagando valor muito abaixo daquele de mercado, infringindo, assim, os artigos 884 a 886 do Código Civil.

Manoel Justino Bezerra Filho ${ }^{308}$ também aponta a inconstitucionalidade do mencionado dispositivo com o contumaz brilhantismo:

Com efeito, o $\S 2^{\circ}$ do art. 27 da Lei 9.514/97, ao prever a possibilidade ser aceito o maior lanço, desde que igual ou superior ao valor da dívida ou de ser simplesmente considerada quitada a dívida e tomado o imóvel -, isto tudo, repita-se, em leilão extrajudicial, sem a garantia do contraditório, está abrindo caminho para que ocorra com imóveis que servem de residência para o adquirente e sua família o que já ocorre há

\footnotetext{
${ }^{307}$ TARTUCE, Flávio; SIMÃO, José Fernando. Direito civil, v. 4: Direito das coisas. São Paulo: Método, 2008, p. 545.

${ }^{308}$ BEZERRA FILHO, op. cit., p. 71.
} 
dezenas de anos com veículos em geral, ou seja: a venda por qualquer preço em leilão extrajudicial, do qual só tomam conhecimento aqueles que se encontram próximos do círculo dominante de poder destes capitais envolvidos. A simples redução do problema à sua proposição mais primária já demonstra a iniquidade da situação: imagine-se que alguém tenha adquiridos um imóvel de R\$150.000,00, tenha honrado $90 \%$ do preço e, por qualquer azar da vida, comum aliás nesta em que o desemprego anula qualquer programação da economia familiar por mais cuidadosa, veja-se impossibilitado de pagar o saldo restante, ou seja, dez por cento do valor do imóvel - perderá o imóvel e perderá tudo que se pagou.

Ora, a situação de iniquidade salta aos olhos, sem contar ainda que o $\S 2^{\circ}$ do art. 27 consagra a possibilidade explícita da venda por preço vil, o que não se aceita sequer em leilão judicial, estabelecido com todas as garantias do contraditório e com a fiscalização do Judiciário e de qualquer interessado, ante a publicidade do processo judicial, publicidade que, como se sabe, não ocorre jamais em processos administrativos internos, conduzidos pelo próprio credor.

Nesse contexto, vale apontar breves considerações sobre a teoria adimplemento substancial que consiste na manutenção do vínculo contratual na hipótese de inexecução da obrigação de pouca importância. O seu objetivo primordial é preservar o contrato de modo a evitar a relativizar a regra absoluta do inadimplemento que causa a resolução do pacto, tal como ocorre na alienação fiduciária em garantia, se o inadimplemento atingir parte tão insignificante que a rejeição do credor torna-se manifestamente contrária ao princípio da boa-fé objetivo que deve nortear as relações contratuais.

Acerca do adimplemento substancial, Junqueira de Azevedo ${ }^{309}$ ensina tal instituto somente estará configurado quando o contratante, embora tenha cumprido parte de suas obrigações, somente deixa de executar uma pequena porção, totalmente insignificante quando comparada ao todo programa contratual. Nessa hipótese, assinala renomado autor, se houvesse a aplicação do direito potestativo resolutório, este seria exercido em dissonância com o princípio da boa-fé objetiva.

309 AZEVEDO, Junqueira de, Insuficiências, deficiências e desatualização do projeto de Código Civil na questão da boa-fé objetiva nos contratos. Revista de Direito dos Tribunais, vol. 775, maio/2000, p. 13-14. 
Dessa forma, é possível afirmar que a teoria do adimplemento substancial deve ser aplicada à Lei $n^{\circ} 9.514 / 97$, notadamente o seu artigo 27, $\S 2^{\circ}$, nas situações em que a inadimplência do devedor-fiduciário for insignificante perante o todo, em respeito aos princípios da proporcionalidade, da boa-fé objetiva e da socialidade.

Como solução para a evidente desproporcionalidade do $\S 2^{\circ}$ do artigo 27 para o fim perseguido, Manoel Justino Bezerra Filho ${ }^{310}$ sugere a alteração da redação do aludido dispositivo legal nos seguintes termos:

No segundo leilão, será aceito o maior lance oferecido, desde que seja igual ou superior a $75 \%$ do valor do imóvel, estipulado na forma do parágrafo anterior, mais as despesas, prêmios de seguros, encargos legais, inclusive tributos, e das contribuições condominiais.

Do exposto, constata-se que a constitucionalidade do leilão extrajudicial, bem como o $\S 2^{\circ}$ do artigo 27 da lei do SFI, estão longe de serem temas pacíficos na jurisprudência e na doutrina nacional.

\subsection{O artigo 53 do Código de Defesa do Consumidor}

A incidência do artigo 53 do Código de Defesa do Consumidor (“CDC”) nos contratos de alienação fiduciária em garantia regulados pela Lei no 9.514/97 é outro tema controvertido na doutrina, havendo argumentos relevantes para as duas correntes doutrinárias.

Aqueles que entendem que o artigo 53 do CDC é aplicável aos contratos de alienação fiduciária de bens imóveis baseiam-se no referido dispositivo, que assim estabelece:

(...) contratos de compra e venda de móveis ou imóveis mediante pagamento em prestações, bem como nas alienações fiduciárias em garantia, consideram-se nulas de pleno direito as cláusulas que estabeleçam a perda total das prestações pagas em benefícios do credor que, em razão do inadimplemento, pleitear a resolução do contrato e a retomada do produto alienado.

Pela leitura do artigo 53 do CDC, verifica-se que as cláusulas que estabeleçam perda total das prestações pagas em benefício do credor-fiduciário serão

${ }^{310}$ BEZERRA FILHO, op. cit., p. 75. 
consideradas nulas de pleno direito, quando pleiteada a resolução do contrato e a retomada do imóvel por força do inadimplemento do devedor-fiduciante.

Ao comentar o artigo 53 do CDC, Nelson Nery Junior ${ }^{311}$ assevera que os contratos de alienação fiduciária em garantia também estão abrangidos pelo aludido dispositivo, uma vez que tais contratos não podem estipular "nem o pacto comissório nem a perda total das prestações pagas pelo consumidor por ocasião do pedido de resolução do contrato ou da retomada do bem feito pelo consumidor, credor-fiduciário."

Continua Nelson Nery Junior, afirmando que o dispositivo veda a pactuação da perda das prestações pagas, o que configuraria vantagem exagerada ao credor-fiduciário em detrimento do devedor-fiduciante, consumidor. Entretanto, observa o autor, é permitido o estabelecimento de pena para o descumprimento da obrigação pelo consumidor.

Para Adroaldo Furtado Fabrício ${ }^{312}$ a doutrina majoritária atual considera a regra do artigo 53 do CDC aplicável aos contratos destinados à aquisição de bens imóveis. Referido autor assinala que, apesar de posterior ao CDC, a lei do SFI não o derrogou nesse ou em qualquer aspecto devendo ser aplicado em todas as situações sob a sua égide, exceto naquelas em que os contratos não sejam de consumo, como, por exemplo, nas relações interempresarias.

Ao defender a incidência do artigo 53 do CDC aos contratos de alienação fiduciária, Manoel Justino Bezerra Filho ${ }^{313}$ também observa que o CDC, embora seja lei ordinária, possui natureza de lei complementar, já que "preenche o expresso campo a ele deixado pelos diversos artigos da Constituição", no caso o inciso XXXII do artigo $5^{\circ}$, o inciso V do artigo 170 e o artigo 48 das Disposições Constitucionais Transitórias que estabeleceu que "o Congresso Nacional, dentro de cento e vinte dias da promulgação da Constituição, elaborará Código de Defesa do Consumidor." Neste diapasão, renomado autor complementa que o Poder Judiciário não poderá de considerar o prevalecimento do CDC sobre a lei do SFI, na medida quem leis de natureza complementar prevalecem sobre aquelas de natureza ordinária naquilo e m que confrontarem.

Seguindo tal raciocínio, Adroaldo Fabrício ${ }^{314}$ explica que a Lei ${ }^{\circ}$ 9.514/97 não criou um direito real de garantia novo, pois a propriedade fiduciária seria

${ }^{311}$ NERY JUNIOR, Nelson. Código brasileiro de defesa do consumidor: comentado pelos autores do anteprojeto. 8. ed., Rio de Janeiro: Forense Universitária, 2005, p. 619.

${ }^{312}$ FABRÍCIO, op. cit., p. 370.

${ }^{313}$ BEZERRA FILHO, op. cit., p. 72.

${ }^{314}$ FABRÍCIO, op. cit., p. 371. 
fruto de uma recombinação de institutos que o ordenamento jurídico já conhecia, razão pela qual não seria possível dizer que a lei do SFI introduziu algum mecanismo que não estivesse contemplado no CDC. Corroborando tal posição, Adroaldo Fabrício lembra que antes mesmo do advento da Lei $n^{\circ}$ 9.514/97 a jurisprudência e a doutrina admitiam a extensão da alienação fiduciária aos bens imóveis.

Como se vê, o fundamento do artigo 53 do CDC é o do não enriquecimento sem causa. O objetivo é evitar que o devedor-fiduciante que não pode mais pagar pelo bem adquirido, além de ficar sem a coisa, fique sem o valor das parcelas pagas.

Em contraposição à posição doutrinária indicada acima, diversos autores entendem que a Lei ${ }^{\circ}$ 9.514/97 prevalece sobre o artigo 53 do CDC.

José Manoel de Arruda Alvim Netto ${ }^{315}$ explica que o CDC é lei geral de proteção ao consumidor, a passo que a Lei nº 9.514/97 é lei especial. Com fundamento no artigo $2^{\circ}, \S 2$, da Lei de Introdução às Normas do Direito Brasileiro, Arruda Alvim afirma que as normas da lei do SFI são incompatíveis com a aplicação do artigo 53 do CDC, contudo, assinala que ambos os diplomas legais sobrevivem porque a Lei $\mathrm{n}^{\mathrm{o}}$ 9.514/97 é lei especial, ocupando o espaço normativo onde não há para o CDC.

Cláudia Lima Marques ${ }^{316}$ também observa que o CDC é lei ordinária e, portanto, havendo eventual conflito com outra lei ordinária haveria a prevalência daquela que fosse especial, quando posterior, uma vez que o "o CDC não regula contratos específicos, mas sim elabora normas de condutas gerais e estabelece princípios, raros serão os casos de incompatibilidade." Havendo incompatibilidade, renomada doutrinadora assevera que prevalecerá a lei especial nova pelos princípios da especialidade e cronologia.

Zilda Tavares ${ }^{317}$ entende pela inaplicação do artigo 53 do CDC aos contratos de alienação fiduciária em garantia de bens imóveis, ressalvando que não ser correto que o valor integral dos valores pagos seja restituído ao devedor-fiduciante, na medida em que este usufruiu do bem durante a vigência do contrato, devendo, portanto, ser abatido, caso a caso, as perdas e danos do bem imóvel.

\footnotetext{
${ }^{315}$ Alvim Betto, op. cit.,

${ }^{316}$ MARQUES, Cláudia Lima, Contratos no código de Defesa do Consumidor, 3. ed., São Paulo: Ed. Revista dos Tribunais, 1998, p. 247.

317 TAVARES, Zilda, Código de defesa do consumidor e a alienação fiduciária imobiliária, São Paulo: Método, 2005, p. 139.
} 
Para Caio Tácito ${ }^{318}$, na alienação fiduciária de bem imóvel, em razão da obrigação legal de realizar o leilão imóvel em caso de inadimplemento do devedorfiduciante, o credor-fiduciário não conserva a propriedade do bem para si. Além disso, ao devedor-fiduciante está assegurada o recebimento da quantia que sobejar o valor da dívida "e, mais ainda, o benefício do perdão da parte remanescente que for coberta pelo lance vencedor." Nesse contexto, aludido autor afirma que não como cogitar-se o enriquecimento indevido do credor-fiduciário, já que "não mais coincidem a acumulação entre dois valores: a manutenção da propriedade e a retenção das parcelas pagas."

Melhim Chalhub ${ }^{319}$ e Marcelo Terra ${ }^{320}$ também compartilham o entendimento acima, asseverando que a Lei $n^{\circ}$ 9.514/97 é norma especial nova em relação ao CDC e, portanto, prevalece sobre ele, devendo-se observar os princípios da função social do contrato e da boa-fé objetiva que devem nortear todos os contratos. Terra ainda cita interessante decisão do extinto $2^{\circ}$ Tribunal de Alçada Civil de São Paulo proferida nos autos da Apelação no 479.247-00/6 que, com base no Decreto-Lei n 911/69 em confronto com o artigo 53 do CDC, que decidiu pela prevalência do aludido decreto-lei, "pois a alienação fiduciária é um contrato com peculiaridades próprias, cuja legislação específica prevê a entrega ao devedor do saldo apurado na venda da coisa."

Recente acórdão proferido pelo Tribunal de Justiça de São Paulo, sob relatoria do Desembargador Oldemar Azevedo, nos autos da Apelação Cível n ${ }^{\circ}$ 400.962.4/0, enfrentou a questão da validade da Lei $n^{\circ}$ 9.514/97 frente às regras do artigo 53 do CDC e decidiu pela validade daquela lei em relação ao CDC.

Ressalve-se que a alienação fiduciária em garantia envolve dois negócios jurídicos interrelacionados: o mútuo (artigo $5^{\circ}$ da lei do SFI) e a alienação fiduciária (artigo 22). Nessa operação, há mútuo, financiamento, garantido pela propriedade fiduciária constituída mediante o registro do contrato de alienação fiduciária perante o competente Registro de Imóveis. O artigo 586 do Código Civil estabelece que o mutuário é obrigado a restituir ao mutuante o que dele recebeu em coisa do mesmo gênero, qualidade e quantidade.

318 TÁCITO, CAIO. Alienação fiduciária - código do consumidor - leilão: o art. 27 da lei n. 9.514/97 é compatível com o art. 53 do código de proteção ao consumidor. Revista de Direito Administrativo, Rio de Janeiro, n. 215, p. 291-294, jan./mar. 1999, p. 292.

${ }^{319}$ CHALHUB, op. cit., p. 303.

320 TERRA, op. cit., p. 73-74. 
Essa previsão do artigo 586 do Código Civil também é determinante para afastar a incidência do artigo 53 do CDC, pois o dinheiro pago pelo devedorfiduciante é do próprio credor-fiduciante, que adiantou a totalidade do montante para o devedor-fiduciante adquirir o imóvel, e este último, por seu turno, se comprometeu a devolver a quantia emprestada no prazo pactuado entre as partes. Entendimento diverso autorizaria o enriquecimento sem causa do mutuante (devedor-fiduciante), que utilizaria o imóvel sem pagar nenhum valor.

\section{Nesse sentido, destaca-se a lição de Zilda Tavares ${ }^{321}$ :}

De fato, ao disciplinar as consequências da mora e do inadimplemento do devedor, a lei da alienação fiduciária de bens imóveis o faz de forma coerente com a hipótese, pois, tratando-se de contrato de mútuo, ao apurar-se o resultado do leilão, na realização da garantia, o credor só pode reter o quantum do seu crédito, mais as despesas, sendo-lhe vedado ficar com o que sobejar. É o que dispõe o $\S 4^{\circ}$, do art. 27, que impõe ao credor o dever de, no prazo de cinco dias, contado da venda do imóvel em leilão, entregar ao devedor o excesso que se verificar.

Efetivamente, a legislação especial da alienação fiduciária impede, por todos os modos, a estipulação de cláusula que preveja a perda, pelo mutuário, das prestações por este pagas, pois institui para esse contrato um regime jurídico próprio que, a par de coibir passo a passo, em todo o curso da formação e da execução do contrato, qualquer eventual abuso do financiador, contém norma imperativa determinando $\left(1^{\circ}\right)$ que o credor promova a venda do imóvel, em leilão, por preço avaliado pelas partes, no prazo máximo de 30 dias após a consolidação da propriedade, e $\left(2^{\circ}\right)$ que o credor entregue ao devedor, nos 5 dias que se seguirem ao leilão, o valor que exceder o quantum da dívida e encargos.

Do exposto, entendemos que o artigo 53 do CDC não se aplica aos contratos de alienação fiduciária de bens imóveis, pois os critérios para antinomia demonstram que a lei do SFI prevalece sobre o CDC, por ser lei nova e específica. Além disso, a Lei $n^{\circ}$ 9.514/97 cuida da preservação do equilíbrio contratual, porquanto não admite o estabelecimento de cláusula de perdimento das parcelas pagas pelo devedorfiduciante.

${ }^{321}$ TAVARES, op. cit., p. 136. 


\section{CAPÍTULO 8 BREVES CONSIDERAÇÕES SOBRE O SISTEMA NORTE-AMERICANO E A CRISE IMOBILIÁRIA}

Conforme examinado no Capítulo 1, o common law também conhecia instituto semelhante ao da fidúcia do tipo romano: o mortgage clássico.

Por meio do mencionado instituto, o fiduciário, originalmente chamado feoffee e, mais tarde, mortgagee, recebia por meio do feoffment with livery of seisin a propriedade de determinada real property (imóvel) do fiduciante feoffor, posteriormente denominado mortgagor a título de garantia do pagamento de uma dívida.

O termo mortgage é composto de duas palavras de origem francesa: "mort", cujo significado é "morte", e "gage", que significa "promessa", portanto, "promessa de morte", que contrastava do "vivum vadium" ou "living pledge" (promessa de vida), pelo qual o devedor, que havia obtido dinheiro emprestado, transferia um imóvel ao seu credor, a fim de que este usasse os frutos da terra até que o débito fosse integralmente quitado de modo que o imóvel jamais "morria" para o devedor.

Já na "mortuum vadium", correspondente ao mortgage, o imóvel permanece na propriedade do credor, sujeito ao cancelamento somente pelo pagamento da dívida na data limite do seu vencimento. Littleton, referido por Samuel W. Eager ${ }^{322}$, explica que o motivo do termo mortgage seria a incerteza acerca do pagamento pelo devedor no prazo convencionado e, se ele não pagasse, a terra, dada em garantia por condição, era tomada dele para sempre, tornando-se, portanto, "morta" perante ao devedor.

Ao receber a propriedade através do feoffment, o mortgagee fiduciário passava a deter o direito pleno, absoluto e ilimitado de propriedade sobre o bem transferido pelo mortgagor fiduciante. Por esse motivo, é possível identificar os seguintes traços comuns entre o mortgage clássico no direito inglês e fiducia cum creditore: a) a transmissão da propriedade por ato solene; b) a celebração de pacto adjeto estabelecendo a obrigação de o credor restituir a propriedade ao devedor originário quando resgatada a dívida; e c) o credor se tornava proprietário pleno da coisa dada em garantia.

Nesse contexto, tal como ocorria na fidúcia do direito romano, o devedor ficava numa posição extremamente vulnerável, já que o credor, como proprietário pleno da coisa dada em garantia, poderia aliená-la a terceiros. Assim, pode-se afirmar que o elemento confiança era essencial no mortgage clássico.

${ }^{322}$ EAGER, op. cit., p. 4. 
A fim de coibir abusos por parte do credor, devedores passaram ao importante órgão jurisdicional da justiça medieval inglesa denominado "Chancellor" (Corte de Chancelaria), que era encarregada da análise de questões de justiça natural não abrangidas pelo common law (nem in ius nem at law). Desse modo, tornou-se prática comum as pessoas que sentiam prejudicadas endereçarem petições diretamente à Chancelaria, a fim de este decidisse a questão controvertida com base na equity.

Ao analisar o caso concreto com base no princípio da equidade, a Chancelaria entendeu ser inadmissível que o mortgagor fiduciante, por não ter cumprido a prestação no dia fixado perdesse definitivamente a propriedade sobre o bem dado em garantia, cujo valor era maior do que o quantum devido. A partir deste entendimento, foi construída a figura típica do direito anglo-saxão denominada equity of redemption.

Pela equity of redemption, passou o devedor a dispor de um remédio que o permitia a pagar a dívida mesmo após o seu vencimento dentro de um prazo razoável. Assim, a equity of redemption passou a ser parte indissolúvel do mortgage, mesmo que no ato constitutivo não se fizesse qualquer referência a ela, era presumida iuris et de iure.

Por outro lado, a equity também se preocupou em atender aos anseios do credor, conferindo a este o direito de propor uma ação visando obrigar o devedor a exercitar o equity of redemption dentro do prazo, sob pena de perda da propriedade. Na hipótese de o devedor não exercitar o equity of redemption no prazo estabelecido, o Tribunal emitia o absolute decree of foreclosure (decreto definitivo de execução da garantia), pelo qual o devedor era privado definitivamente da propriedade, sem a possibilidade de sequer efetuar o pagamento.

Apesar de dispor da figura do absolute decree of foreclosure, o credor deixou de ter uma garantia robusta, pois não mais tinham a certeza acerca da titularidade sobre o bem dado em garantia, na medida em que o devedor passou a deter o direito de remir o bem através do equity of redemption.

Dessa forma, surgiu para o credor a necessidade de criar uma nova modalidade de mortgage capaz de transferir a propriedade da coisa dada em garantia para si e, ao mesmo tempo, conferir ao devedor a possibilidade de ser restituído no domínio pleno do bem quando cumprida a obrigação. Assim surgiu a figura da "conveyance in fee subject to defeanse", pela qual a coisa dada em garantia tinha sua titularidade transmitida ao credor sob condição específica, qual seja, o pagamento da dívida pelo devedor. 
Com a evolução dos institutos do mortgage e do conveyance in fee subject to defeanse, o credor constatou a desnecessidade de permanecer na posse da coisa dada em garantia pelo devedor, porquanto detinha a sua propriedade, a qual, mesmo limitada, o autorizava a executar a dívida através da alienação do bem a terceiros (foreclosure) em caso de inadimplemento do devedor.

\subsection{A figura do mortgage no direito norte-americano}

Dada a evidente influência do direito inglês, os Estados Unidos adotaram a figura do mortgage e cada estado norte-americano adaptou aludido instituto de acordo com a sua realidade: enquanto alguns mantiveram a natureza original do mortgage, com a transferência da propriedade da coisa dada em garantia ao credor, outros optaram por apenas gravar o bem com um ônus (lien), permanecendo a titularidade do bem com o devedor, tal como ocorre com o instituto da hipoteca.

Alex M. Johnson ${ }^{323}$ explica que o mortgage residencial apenas passou a ser utilizado após a Grande Depressão de 1930, quando diversos devedores inadimplentes perderam seus imóveis por conta crise que assolou o país e não mais tinham condições de adquirir uma nova propriedade mediante pagamento à vista. Objetivando combater a escassez de moradia, o governo norte-americano encontrou no mortgage residencial uma saída para sanar o problema e permitir a aquisição da moradia a prazo pelo devedor e, ao mesmo tempo, conferir uma garantia robusta ao credor, qual seja, a propriedade do próprio imóvel adquirido pelo devedor.

A grande vantagem de o credor ter o mortgage sobre determinado bem imóvel do devedor é a possibilidade de aliená-lo a terceiros por meio do foreclosure conduzido pelo próprio credor. Tal figura se assemelha ao público leilão previsto na lei do SFI, que determina a realização do leilão extrajudicial pelo credor-fiduciário no prazo de trinta dias a contar da consolidação da propriedade.

Referido autor estadunidense também aponta o surgimento de outro instituto fomentador do crescimento imobiliário norte-americano: o deed of trust, o qual, curiosamente, possui semelhanças com a alienação fiduciária em garantia de bem imóvel do nosso ordenamento.

${ }^{323}$ JOHNSON JR., Alex M., Preventing a return engagement: Eliminating the mortgage purchaser's status as a hold-in-due-course: Properly aligning incentives among the parties, In Pepperdine Law Review, vol. 37, n. 2, 2010, p. 531. 
Alguns estados norte-americanos, dentre eles, o estado da Virginia, entendem que a possibilidade de o credor conduzir o foreclosure do bem dado em garantia permitiria a prática de abusos por parte do credor. Afinal, o mortgage permite que o credor continue a cobrar a dívida do devedor caso a alienação do bem a terceiros através do foreclosure não satisfaça integralmente o débito por meio do instituto denominado "deficiency judgment".

Em razão do aparente conflito de interesses, esses estados criaram a figura do deed of trust, a fim de evitar que o credor conduza o procedimento de foreclosure e mais tarde use a insuficiência do valor obtido para continuar a cobrança do saldo devedor por meio do deficiency judgment. Portanto, o deed of trust tem como escopo proteger o direito do devedor de controlar o procedimento do foreclosure e até mesmo oferecer lance no público leilão, a fim de evitar o deficiency judgment.

A estrutura do deed of trust é muito similar a do mortgage, na medida em que dois instrumentos são celebrados para criá-lo: o negotiable note que materializa a existência do débito, ou seja, o título, e o deed of trust propriamente dito, que estabelece os direitos e deveres das três partes envolvidas na operação: o trustor, o beneficiary e o trustee.

O trustor é o devedor, é aquele que toma emprestado determinado quantia em dinheiro para aquisição de determinado imóvel. A obrigação do trustor é efetuar pagamentos mensais ao beneficiary (credor) de modo a amortizar a sua dívida. Outra importante obrigação do trustor diz respeito à transferência da titularidade do imóvel adquirida para o trustee para assegurar a obrigação de pagar a dívida. Concretizada a transferência, o trustee passa a figurar como legal owner do bem, ou seja, passa a deter a propriedade formal do imóvel, ao passo que ao trustor passa a deter a propriedade material, sendo, pois, denominado equitable owner.

O beneficiary é o credor, cuja obrigação é receber os pagamentos mensais efetuados pelo trustor ao trustee. Se o trustor deixar de pagar a sua dívida, a depender dos termos do deed of trust, ou o beneficiary deverá solicitar ao trustee que inicie os procedimentos de foreclosure ou tal procedimento terá seu início automático, independentemente de qualquer comunicação do beneficiary.

O trustee é a terceira parte do deed of trust, que lhe confere uma peculiaridade singular. Teoricamente o trustee á uma terceira parte independente que deve agir de acordo com os termos estipulados no deed of trust, mantendo uma relação de 
confiança entre o trustor e o beneficiary. Todavia, Alex M. Johnson Jr. ${ }^{324}$ observa que a prática é totalmente diversa da teoria: o trustee é geralmente nomeado pelo beneficiary e seus interesses estão alinhados com aqueles do beneficiary. As obrigações do trustee são basicamente duas: (i) recolher os valores pagos pelo trustee e encaminhá-los ao beneficiary; e (ii) na hipótese de inadimplemento do trustee, conduzir os procedimentos de foreclosure para alienação do imóvel dado em garantia de modo a garantir ao máximo a satisfação do beneficiary.

Além do deed of trust, o direito norte-americano também possui outro instituto que surgiu como alternativa ao mortgage. Trata-se da Installment Land Sale Contract ("ILSC"), figura que se assemelha ao nosso compromisso de compra e venda.

Pelo ILSC, o prazo para pagamento do imóvel pelo comprador é estendido por anos. Ao celebrar o contrato, o comprador toma posse do imóvel imediatamente, devendo pagar ao vendedor uma quantia mensal de forma a amortizar o valor total da dívida. O ILSC é um instrumento normalmente utilizado por aqueles que não se qualificam para o mortgage convencional.

No ILSC, apesar de o vendedor permanecer com a titularidade do imóvel, a posse e a obrigação de pagar impostos e outros encargos são transmitidos para o comprador, assim como o risco de perda, a depender do estado onde o imóvel está localizado.

No tocante à execução da garantia pelo procedimento do foreclosure, verifica-se que tal procedimento varia de estado para estado, podendo ele ser judicial, tal qual ocorre na Califórnia, por exemplo, ou extrajudicial, como é o caso do estado de Nova Iorque. A duração do procedimento de foreclosure também varia de estado para estado: enquanto alguns levam de um a dois meses para serem concluídos, outros chegam a seis meses.

Assim como ocorre na alienação fiduciária em garantia de bem imóvel, no foreclosure, o produto da alienação em público leilão deverá ser entregue primeiramente ao credor. Como o devedor também pode constituir mais de um mortgage sobre o mesmo imóvel, assim como na hipoteca, eventual saldo remanescente deverá ser destinado ao pagamento dos demais credores do devedor titulares de mortgage sobre o imóvel. Caso eventual valor ultrapasse o valor da dívida, o saldo remanescente deverá ser destinado ao devedor, a fim de evitar o enriquecimento indevido do credor.

${ }^{324}$ JOHNSON JR., Alex M., Modern Real Estate, vol. 1, Charlottesville: University of Virginia School of Law, 2011, p. 39. 
Vale destacar que o equity of redemption ainda persiste no direito norte-americano de forma a assegurar ao devedor o direito de remir o imóvel objeto do mortgage antes ou até mesmo depois do foreclosure, a depender do estado. Nesta última hipótese, o devedor poderá remir o imóvel dentro de um período previsto em lei, arcando com as despesas envolvidas na execução da garantia.

Com o passar dos anos, o governo norte-americano percebeu a necessidade de maior circulação de riqueza entre os estados para aquisição de imóveis. Todavia tal objetivo tinha um obstáculo: as regras que regulavam o mortgage variavam e ainda variam de estado para estado, impedindo que os bancos localizados nos estados mais prósperos da nação se sentissem seguros para destinar vultosas quantias para financiar a aquisição de imóveis localizados em outros estados.

A fim de ultrapassar essa barreira que obstava a circulação do capital destinado ao financiamento imobiliário, o governo estadunidense criou o mercado secundário de mortgage capaz de permitir a captação de capital para o financiamento imobiliário sem a necessidade das fontes originárias de crédito, como as instituições financeiras. Assim, foram criadas pelo governo norte-americano as três principais entidades reguladoras e uniformizadoras do mercado secundário de mortgage: a Federal National Mortgage Association ("FNMA"); a Federal Home Loan Mortgage Corporation ("FHLMC”); e a Government National Mortgage Association (“GNMA”).

Tal medida revelou-se bem sucedida e efetivamente alcançou o objetivo incialmente traçado, com a padronização a nível nacional das regras necessárias para constituição do mortgage e para a negociação dos empréstimos hipotecários ("mortgage loans") no mercado secundário.

\subsection{A crise imobiliária norte-americana}

Este trabalho não tem a pretensão de elucidar os diversos questionamentos que surgiram após a crise imobiliária norte-americana, mas, sim, expor de forma breve as causas que levaram ao grave impacto sofrido no mercado imobiliário norteamericano no ano de 2008 e as suas graves consequências para a economia mundial.

Conforme exposto acima, a aquisição da casa própria nos Estados Unidos mediante o pagamento em prestações, tendo como garantia o mortgage, surgiu 
após a Grande Depressão de 1930 por conta do colapso do mercado imobiliário. Alex M. Johnson Jr. chega a afirmar que talvez este tenha sido o melhor produto da Grande Depressão. $^{325}$

Não obstante a influência das chamadas modalidades de financiamentos exóticos ("exotic financing devices") na crise imobiliária norte-americana, Alex M. Johnson $\mathrm{Jr}^{326}$ aponta como sua principal causa o subprime mortgages e o predatory lending (empréstimo predatório).

O subprime mortgage é definido com base na definição de prime mortgage, que é aquele empréstimo concedido para devedores com sólido histórico de crédito, sem, por exemplo, qualquer registro de atraso de pagamentos. A partir deste histórico, o credor apura o nível de credibilidade do devedor, que poderá ser ou não considerado aceitável. Consequentemente, o subprime mortgage pode ser definido como sendo o que eles não é: prime mortgage. Em outras palavras, no subprime mortgage, o devedor representa um risco maior de inadimplemento em comparação com aqueles com bom histórico.

Em relação ao empréstimo predatório, Alex M. Johnson Jr. assinala que sua definição é mais complexa, porquanto depende de uma série de fatores. Em suma, trata-se de um conjunto de artifícios usados por mutuantes com o objetivo de tirar proveito da complexidade do processo de concessão/obtenção do mortgage e da ingenuidade financeira de devedores, a fim de cobrar excessivas taxas de juros muito maiores daquelas cobradas dos devedores considerados prime.

$\mathrm{O}$ ponto de encontro entre o subprime mortgage e o empréstimo predatório reside no lucro inicial obtido pelo originador do mortgage no momento da sua celebração e antes da transferência do mortgage note ("título de crédito") no mercado

${ }^{326}$ JOHNSON JR., op. cit., p. 543. 
secundário. A pessoa que inicia o processo de contratação do mortgage e que trata diretamente com o devedor tem um grande incentivo (dinheiro) para celebrar o contrato. Pouco importa para o originador do mortgage se ele é prime ou subprime, pois os seus honorários não dependem da qualidade do mortgage ou do cumprimento da obrigação pelo devedor.

Visando ilustrar um caso emblemático de empréstimo predatório tendo como garantia um subprime mortgage, destaca-se o caso Soledad Aviles vs. Washington Mutual Bank julgado pela Corte da Califórnia.

Soledad Aviles comprou uma residência na Califórnia pelo valor de US\$ 615,000.00 (seiscentos e quinze mil dólares norte-americanos) obtidos a partir de um formulário de empréstimo preenchido por um corretor de empréstimo e financiado originalmente pelo Washington Mutual Bank. Soledad Aviles era um cortador de vidro e percebia um salário de US $\$ 9,00$ por hora.

O corretor informou ao Sr. Aviles que o valor da parcela mensal do mortgage seria de US\$ 3,600.00 (três mil e seiscentos dólares norte-americanos) na época da celebração do contrato. Sr. Aviles imaginava que poderia pagar montante com a renda adicional de sua esposa e de três de suas seis filhas.

Assim, confiando na palavra do correto, Sr. Aviles assinou os contratos e documentos escritos em inglês, língua que ele sequer falava ou lia. Posteriormente, Sr. Aviles foi surpreendido ao tomar conhecimento de que o valor mensal da prestação era, na verdade, US\$ 4,800.00 (quatro mil e oitocentos dólares norteamericanos), um valor que o obrigou a alugar os quartos, a garagem e o porão, enquanto ele e sua esposa dormiam no sofá.

Sr. Aviles disse desconhecer que o formulário de empréstimo que ele assinara informava que a sua renda mensal era de US\$7,400.00 e que sua filha 
percebia o montante de US\$ 5,700.00 por mês, totalizando uma suposta renda anual de US\$157,000,00, enquanto, na verdade, a renda anual de sua família era de US\$ 60,000.00.

Após cinco meses de inadimplência, Sr. Aviles estava desesperado para vender a sua propriedade antes do procedimento de foreclosure ser instaurado pelo banco credor.

O caso do Sr. Aviles não é o único nos Estados Unidos e representa uma dentre milhares de situações em que o devedor contrata um empréstimo para aquisição da casa própria, dando em garantia a própria propriedade (mortgage), para, posteriormente, perceber que não tinha condições de adimplir a obrigação. Por que alguém ajudaria o devedor a celebrar este tipo de negócio ciente de que ele não reunia condições de efetuar os pagamentos? Segundo Alex M. Johnson $\mathrm{Jr}^{327}$ a resposta para pergunta recai sobre os honorários percebidos pelo corretor de empréstimo que deu origem ao mortgage.

Diante desse cenário, o mercado hipotecário norte-americano, que operava com um valor de US\$ 10 bilhões, passou a ter uma parcela de empréstimo subprime correspondente a $13 \%$ deste total, que era também comercializada no mercado secundário por instituições financeiras sem qualquer tipo de controle.

O momento econômico vivido no mundo naquela época permitia crer que os mutuários continuariam a pagar seus empréstimos e o ciclo até então virtuoso continuaria a existir. Entretanto, em meados de agosto de 2007, o cenário econômico norteamericano começou a mudar radicalmente em razão da impossibilidade dos mutuários subprime, a maioria vítima de empréstimos predatórios tal qual acima descrito, de honrarem suas dívidas. Tal fato aliado a diversos fatores, como a elevação das taxas de juros de mortgage, a redução do valor dos imóveis, e, principalmente, a má avaliação dos

${ }^{327}$ JOHNSON JR., op. cit., p. 548. 
empréstimos subprime pelos operadores do mercado secundário e a ausência de fiscalização do governo norte-americano, acabou por resultar na crise de 2008.

O mercado imobiliário estadunidense entrou em colapso, já que o número crescente de inadimplementos e de procedimentos de foreclosure (que resultava no aumento do número de imóveis no mercado) acarretava na redução do valor dos imóveis (a oferta de imóveis era maior que a procura), deixando, por consequência, elevados saldos devedores em aberto.

Diante desse contexto, vale transcrever a interessante conclusão apresentada por Ivandro Ristum Trevelim ${ }^{328}$ sobre a origem imobiliária norte-americana:

Percebe-se então que o maior problema atual enfrentado nos Estados Unidos da América com o mortgage, enquanto garantia utilizada na concessão de empréstimos e financiamento imobiliário, é que a sua execução funciona, e este sucesso acaba sendo a sua própria fraqueza, pois em poucos meses milhares de pessoas podem ficar sem suas casas, causando um problema social bastante relevante para ser enfrentado por qualquer país. A execução da garantia é tão rápida que já se instaurou um debate sobre outras modalidades de solução que poderia ser utilizadas alternativamente à execução hipotecária.

Decorridos cinco anos do início da crise financeira mundial originada a partir do colapso no mercado imobiliário norte-americano, verifica-se que a tomada de diversas medidas pelo governo dos Estados Unidos e de outros países para coibir os efeitos da crise começam a surtir efeito e a tendência é que em breve a economia mundial se restabeleça, dando início à uma nova fase de prosperidade.

328 TREVELIM, Ivandro Ristum. A alienação fiduciária em garantia e sua aplicação no mercado financeiro imobiliário, 213 p. Dissertação (Mestrado) em Direito. Faculdade de Direito. Universidade de São Paulo, 2008, p. 196. 


\section{CONCLUSÃO}

A alienação fiduciária em garantia teve sua origem no direito romano através do instituto da fidúcia. Embora semelhantes, verifica-se que dois aspectos distinguem as duas figuras:

1) Na fidúcia do tipo romano, o elemento confiança é essencial para caracterização do negócio. O fiduciante transmite a propriedade plena da coisa ao fiduciário confiando que este a restituirá assim que verificada determinada condição. A depender da modalidade da fidúcia - fiducia cum amico ou fiducia cum credito -, a condição poderá ser a interrupção de uma ameaça ao fiduciante, por exemplo (fiducia cum creditore) ou o pagamento de uma dívida (fiducia cum creditore). Já na alienação fiduciária de bens imóveis, a confiança é inexistente, porquanto a Lei nº 9.514/97 preenche tal lacuna de modo a proteger o devedor-fiduciante contra a prática de eventual abuso pelo credor-fiduciário, como, por exemplo, a alienação do bem dado em garantia para terceiro.

2) Enquanto na fidúcia do tipo romano, o fiduciário recebia a plena propriedade da coisa transmitida pelo fiduciante, com todas as faculdades a ela inerentes: uso, gozo e disposição. Alguns fiduciários inescrupulosos, abusando da confiança depositada pelo fiduciante, chegavam a alienar a terceiros a coisa dada em garantia. Neste caso, restava ao fiduciante tão-somente pleitear indenização por perdas e danos. Na alienação fiduciária em garantia de bens imóveis, a lei do SFI estabelece que o credorfiduciário receberá a propriedade resolúvel, portanto, limitada, do imóvel objeto da garantia, bem como a sua posse indireta. Em contrapartida, a Lei ${ }^{\circ}$ 9.514/97 assegura ao devedor-fiduciante a livre disposição do imóvel, desde que este esteja adimplente com suas obrigações. Assim, o credor-fiduciário está impossibilitado de praticar atos que possam perturbar a livre disposição do imóvel pelo devedor-fiduciante. Mesmo na hipótese de o 
credor-fiduciário vir a ser consolidado na propriedade do imóvel dado em garantia em razão do inadimplemento do devedor-fiduciante, a lei do SFI determina que o credorfiduciário deve levar o bem a público leilão no prazo de trinta dias a contar da consolidação da propriedade.

Outro aspecto da propriedade fiduciária imobiliária diz respeito à natureza da propriedade recebida pelo credor-fiduciário a título de garantia. Alguns autores a comparar com a natureza da propriedade recebida pelo trustee na operação de trust no common law.

O trust tem como fundamento básico a dupla propriedade sobre o mesmo bem: a propriedade formal ou nominal (legal property) e a propriedade substancial ou de fruição (equitable property). Entretanto, essa divisão de propriedade é uma noção incompatível com os sistemas de filiação romana, tal como o brasileiro, no qual prevalece o princípio da unicidade do domínio e da incindibilidade do direito subjetivo do proprietário. Assim, no trust, ao trustee caberá a propriedade formal e ao beneficiário a propriedade de fruição, ao passo que na alienação fiduciária de imóvel, caberá ao credorfiduciário a propriedade resolúvel e limitada do bem dado em garantia.

Dentre os institutos do common law examinados neste trabalho, depreende-se que, apesar de não serem institutos idênticos, as estruturas da alienação fiduciária em garantia e do chattel mortgage são extremamente semelhantes. Enquanto na alienação fiduciária há transferência da propriedade fiduciária ao credor sob condição resolutiva (pagamento da dívida pelo devedor) e o desdobramento da posse em direta e indireta, sendo que o devedor permanece na posse direta do bem, na chattel mortgage ocorre processo semelhante, porém dentro das peculiaridades do common law, porquanto o credor recebe a propriedade formal também sob condição resolutiva e o devedor remanesce com a propriedade de fruição, figura semelhante à posse direta no civil law. 
No Brasil, a propriedade fiduciária imobiliária encontrou campo fértil para seu nascimento e desenvolvimento com o descrédito da hipoteca, com a lentidão dos atos para sua constituição, com o assoberbamento do Poder Judiciário e com as discussões que orbitam em torno do Decreto-Lei $n^{\circ} 70 / 66$ e da Lei $n^{\circ} 5.741 / 71$. Não há margem para dúvida sobre o total descompasso entre os mecanismos de recuperação de crédito pela garantia hipotecária e a atual conjectura econômica.

E é nesse contexto que surge a propriedade fiduciária em garantia surge como nova modalidade de garantia real justamente para preencher a lacuna deixada pela hipoteca. A alienação fiduciária atenua as dificuldades enfrentadas na execução dos tradicionais instrumentos de garantia, na medida em que oferece maior rigor e eficiência na segurança do crédito.

De um modo geral, é possível indicar as três principais inovações introduzidas pela Lei $\mathrm{n}^{\circ}$ 9.514/97 como sendo: a) a criação de um novo título de crédito, lastreado em crédito imobiliário; b) a previsão de funcionamento de companhias destinadas à aquisição e à securitização de créditos imobiliários, mediante a emissão e circulação dos idealizados CRI - Certificados de Recebíveis Imobiliários; e c) a regulamentação da alienação fiduciária em garantia de bens imóveis.

Assim, após quinze anos da vigência da Lei no 9.514/97, é possível afirmar que o instituto da alienação fiduciária em garantia surgiu como um importante instrumento de fomentação do crédito no setor imobiliário, propiciando ao investidor uma forma segura e eficaz de recuperar o seu investimento, na hipótese de inadimplemento do devedor, além de instituir um novo e atrativo título de crédito - Certificado de Recebível Imobiliário - lastreado na segurança da propriedade imobiliária e com a negociabilidade dos valores mobiliários.

Vale também destacar que a Lei $n^{\circ}$ 9.514/97 alberga duas figuras jurídicas distintas, porém intimamente interligadas: (i) a alienação fiduciária em garantia; e (ii) a propriedade fiduciária. A alienação fiduciária em garantia é apenas o contrato que serve de título para constituição da propriedade fiduciária, esta, sim, garantia real. Isso também ocorre com as demais modalidades de garantia real previstas no nosso ordenamento. Por exemplo, para constituição da hipoteca, necessário se faz a celebração de um contrato de hipoteca (título), o qual, após ser registrado no competente Cartório de Registro de Imóveis, constituirá a hipoteca, que é a garantia real propriamente dita. O mero contrato de hipoteca não tem o condão de criar a garantia real, fato que somente se concretiza mediante o seu registro no Registro de Imóveis. 
Esse desdobramento em dois momentos distintos para constituição da garantia real encontra respaldo nos artigos 1.227 e 1.245 do Código Civil, os quais, respectivamente, estabelecem a necessidade da celebração de um contrato, de um título, destinado à aquisição, constituição ou transferência de um determinado direito ou ônus real, e o seu correspondente registro.

Atento à imperfeição da redação da Lei no 4.728/65 e do DecretoLei n ${ }^{\circ}$ 911/69, o legislador da Lei $n^{\circ} 9.514 / 97$ procurou diferenciar as figuras da alienação fiduciária em garantia e da propriedade fiduciária de forma a não permitir qualquer equívoco quanto à sua interpretação.

Em relação à comparação com institutos afins, a alienação fiduciária em garantia de bens imóveis revela-se sui generis. Apesar de guardar algumas semelhanças com algumas figuras, como, por exemplo, o negócio fiduciário, a alienação fiduciária tem características próprias.

No tocante à execução da garantia em caso de inadimplemento do devedor-fiduciante, verifica-se que a lei do SFI buscou conferir celeridade à recuperação do crédito pelo credor-fiduciário. O objetivo dessa medida foi justamente propiciar meios para o capital ser direcionado ao financiamento imobiliário da forma menos onerosa possível, já que o credor-fiduciário saberá que, na hipótese de inadimplemento do devedorfiduciante, seu crédito será satisfeito de forma célere e eficaz.

Assim, os leilões extrajudiciais revelam-se essenciais para o objetivo da lei, pois são eles que asseguram ao credor-fiduciário uma execução mais célere do que aquela promovida via judicial. Nesse contexto, foi possível apurar que a constitucionalidade dos leilões extrajudiciais ainda é objeto de questionamento pela doutrina e pela jurisprudência.

A nosso ver, o procedimento do leilão extrajudicial per si não é inconstitucional, porquanto é assegurado ao devedor-fiduciante o direito ao contraditório e à ampla defesa durante todo o procedimento.

Por outro lado, a previsão do $\S 2^{\circ}$ do artigo 27 , da lei do SFI, nos parece desmedida, razão pela qual entendemos que a teoria do adimplemento substancial deve ser aplicada à Lei $n^{\circ}$ 9.514/97 nas situações em que a inadimplência do devedorfiduciário for insignificante perante o todo, em respeito aos princípios da proporcionalidade, da boa-fé objetiva e da socialidade.

Neste aspecto, concordamos com a solução para a desproporcionalidade do $\S 2^{\circ}$ do artigo 27 para o fim perseguido apresentada por Manoel 
Justino Bezerra Filho ${ }^{329}$ mediante a alteração da redação do aludido dispositivo legal nos seguintes termos:

No segundo leilão, será aceito o maior lance oferecido, desde que seja igual ou superior a $75 \%$ do valor do imóvel, estipulado na forma do parágrafo anterior, mais as despesas, prêmios de seguros, encargos legais, inclusive tributos, e das contribuições condominiais.

Em relação à incidência do artigo 53 do $\mathrm{CDC}$, os tribunais brasileiros já se manifestaram pela a sua não aplicação aos contratos de alienação fiduciária, na medida em que a Lei $\mathrm{n}^{\circ}$ 9.514/97 contém estrutura legal específica para a execução da garantia e, caso o valor obtido no leilão extrajudicial ultrapasse o valor da dívida, é assegurado ao devedor-fiduciante o recebimento do saldo que sobejar. Portanto, a Lei $\mathrm{n}^{\circ}$ 9.514/97 prevalece sobre o CDC com fundamento no princípio da especialidade.

Ademais, pelo princípio da cronologia, depreende-se que a lei do SFI foi introduzida em nosso ordenamento seis anos depois da vigência do CDC. Sendo as duas leis hierarquicamente equivalentes (leis ordinárias), a lei do SFI prevalece sobre o CDC, nos termos do $\S 2^{\circ}$, do artigo $2^{\circ}$, da LINDB.

Do exposto, verifica-se que a propriedade fiduciária de bens imóveis é modalidade de garantia real sui generis, capaz de atender aos anseios do credor-fiduciário na hipótese de insolvência do devedor-fiduciante de forma célere e eficaz. Todavia, não se pode deixar de lado a busca por uma execução justa e equilibrada de forma a respeitar os direitos do devedor-fiduciante, notadamente o seu direito de permanecer no imóvel quando cumprida quase que totalmente a sua obrigação (teoria do adimplemento substancial).

${ }^{329}$ BEZERRA FILHO, op. cit., p. 75. 


\section{REFERÊNCIAS BIBLIOGRÁFICAS}

ABRÃO, Carlos Henrique. Alienação fiduciária imobiliária. Revista de Direito Bancário e do Mercado de Capitais, São Paulo, v. 3, n. 10, p. 251-256, out./dez. 2000.

ALVES, André Cordelli, Alienação fiduciária em garantia de bens imóveis, Revista de Direito Bancário e do Mercado de Capitais, vol. 56, p. 171, Abr/2012.

ALVES, Vilson Rodrigues. Alienação fiduciária. 3. ed. São Paulo: BH Editora, 2012. 807 p. ISBN 978-85-88239-72-2.

ANDRADE, José Alfredo Ferreira de, Da alienação fiduciária em garantia, São Paulo: Livraria e Editora Universitária de Direito Ltda., 1970.

ALMEIDA, José Raul Gavião de. Prisão civil em contrato de alienação fiduciária. Revista dos Tribunais, São Paulo, v. 71, n. 563, p. 42-47, set. 1982.

ALVIM NETTO, José Manoel de Arruda. Alienação fiduciária de bem imóvel. O contexto da inserção do instituto (Parecer). In: Alienação fiduciária e direito do consumidor. São Paulo: Abecip, (s.d), p. 4-36.

ASCARELLI, Tullio. Problemas das sociedades anônimas e direito comparado. $1^{\mathrm{a}}$ ed. Campinas (SP): Bookseller, 2001.

ASCENSÃO, José de Oliveira. Direitos reais. 5ª ed. Coimbra: Coimbra Editora, 2000.

AZEVEDO, Álvaro Villaça. Alienação fiduciária de bem imóvel. In: Direito civil e processual civil. Vol. 1. Porto Alegre: Magister, 2004. p. 41-49.

AZEVEDO, Álvaro Villaça. Alienação fiduciária em garantia de bem móvel e imóvel. Revista da Faculdade de Direito, São Paulo, Fundação Armando Álvares Penteado (Faap), ano 1, n. 1, p. 61-84, 2002. 
AZEVEDO, Álvaro Villaça, Contratos inominados ou atípicos e negócio fiduciário, 3. ed., Belém, CEJUP, 1988.

AZEVEDO, Álvaro Villaça, Prisão civil por dívida, 2. ed., rev., atual. e ampl., São Paulo: Ed. Revista dos Tribunais, 2000.

AZEVEDO, Álvaro Villaça. Teoria geral dos contratos típicos e atípicos. $3^{a}$ ed. São Paulo: Atlas, 2009.

AZEVEDO, Junqueira de, Insuficiências, deficiências e desatualização do projeto de Código Civil na questão da boa-fé objetiva nos contratos. Revista de Direito dos Tribunais, vol. 775, maio/2000.

AZEVEDO JÚNIOR, José Osório de. Compromisso de compra e venda. 5ed. rev. e atual. São Paulo: Malheiros, 2006.

BALBINO FILHO, Nicolau. Contratos e notificações no registro de títulos e documentos. $4^{\text {a }}$ ed. São Paulo: Saraiva, 2002.

BALBINO FILHO, Nicolau. Registro de imóveis: doutrina, prática, jurisprudência. $13^{\mathrm{a}}$ ed., rev. e atual. São Paulo: Saraiva, 2008.

BEZERRA FILHO, Manoel Justino. A execução extrajudicial do contrato de alienação fiduciária de bem imóvel: exame crítico da Lei 9.514, de 20.11.1997. Revista dos Tribunais - Papel, v. 93, n. 819, p. 65-76, jan. 2004.

BECK DA SILVA, Luiz Augusto. Alienação fiduciária em garantia: história, generalidades, aspectos processuais, ações, questões controvertidas, legislação e jurisprudência. Rio de Janeiro: Forense, 1998.

BESSONE, Darcy. Da compra e venda: promessa \& reserva de domínio. $3^{\text {a }}$ ed. São Paulo: Saraiva, 1998.

BESSONE, Darcy. Direitos reais. 1ª ed. São Paulo: Saraiva, 1988. 
BEVILÁQUA, Clóvis. Direito das coisas. 4ª ed. Rio de Janeiro: Forense, 1956.

BUNAZAR, Maurício. Do compromisso de compra e venda: uma estrutura naturalmente funcionalizada. In DELGADO, Mário Luiz; ALVES, Jones Figueiredo (coord.). Novo código civil: questões controvertidas - volume 7. São Paulo: Editora Método, 2006.

BUZAID, Alfredo. Ensaio sobre a alienação fiduciária em garantia. São Paulo: ACREDFI, 1969.

CAMBLER, Everaldo Augusto. O Sistema Financeiro Imobiliário e a execução extrajudicial no âmbito da lei n. 9514/1997. In: DIREITO imobiliário: questões contemporâneas. Rio de Janeiro: Elsevier, 2008. p. 181-193.

CAMINHA, Uinie. Securitização. 2. ed. São Paulo: Saraiva, 2007.

CHANAN, Guilherme Giacomelli. Alienação fiduciária: direito material e processual. Revista Jurídica, São Paulo, v. 54, n. 350, p. 39-53, dez. 2006.

CHALHUB, Melhim Namem. A fidúcia no sistema de garantias reais do direito brasileiro. Revista de Direito Bancário e do Mercado de Capitais, São Paulo, v. 1, n. 2, p. 113-139, Maio / Ago. 1998.

CHALHUB, Melhim Namem. A Lei 9.514, de 20.11.97. Os procedimentos de realização da garantia fiduciária à luz dos princípios enunciados pelo artigo 53 da Lei n. 8.078, de 11 de setembro de 1990 (Código de Defesa do Consumidor). (Parecer). In: Alienação fiduciária e direito do consumidor. São Paulo: Abecip, (s.d.). p. 57-88.

CHALHUB, Melhim Namem. Negócio fiduciário. 3ª ed. Rio de Janeiro: Renovar, 2006.

CHALHUB, Melhim Namem, Negócio fiduciário, 4. ed., rev. e atual. Rio de Janeiro: Renovar, 2009. 
CHALHUB, Melhim Namem. Trust: breves considerações sobre sua adaptação aos sistemas jurídicos de tradição romana. Revista dos Tribunais, São Paulo, v. 90, n. 790, p. 79-113, Ago. 2001.

CHALHUB, Melhim Namem; e Afranio Carlos Camargo Dantzger. Alienação Fiduciária de Bens Imóveis em segundo grau?, disponível em http://www.anoreg.org.br/index.php?option=com_content\&view=article\&id=13561:import ed_13551\&catid=32:artigos\&Itemid=12. Último acesso: 6 Jan. 2013.

CLÁPIS, Alexandre Laizo, A propriedade fiduciária imobiliária - aspectos gerais e registrários, 271 p. Dissertação (Mestrado) em Direito Civil. Faculdade de Direito. Pontifícia Universidade Católica de São Paulo, 2010.

COUTO e SILVA, Clóvis V. A obrigação como processo. Rio de Janeiro: Editora FGV.

CRETELLA JÚNIOR, José. Curso de direito romano: o direito romano e o direito civil brasileiro no Novo Código Civil. 30ª ed., rev., aum. Rio de Janeiro: Forense, 2007.

DANTAS, Francisco Clementino San Tiago, Programa de direito civil III: direito das coisas, Rev. do texto e anotações de José Gomes de Bezerra Câmara. Atualização de Laerson Mauro. Rio de Janeiro: Ed. Rio, 1979.

DANTZGER, Afranio Carlos Camargo. Alienação fiduciária de bens imóveis. São Paulo: Método, 2005.

DE CICCO, Maria Cristina. Alienazione fiduciaria in garanzia il modelo brasiliano. Napoli: Edizioni Scientifiche Italiane, 1996.

DINAMARCO, Cândido Rangel. Alienação fiduciária de bens imóveis (parecer). Revista de Direito Imobiliário, São Paulo, v. 24, n. 51, p. 235-252, Jul. / Dez. 2001.

DINIZ, Maria Helena. Curso de direito civil brasileiro - v. 4: direito das coisas. 22. ed. São Paulo/SP: Saraiva, 2007. 7 v. 
EAGER, Samuel W. The law of the chattel mortgages and sales and trust receipts with forms. 1941, Buffalo: Law Book Publishers.

ESPÍNOLA, Eduardo. Sistema do direito civil. Rio de Janeiro: Editora Rio, 1977.

FABRÍCIO, Adroaldo Furtado. A alienação fiduciária de imóveis segundo a Lei $\mathrm{n}^{\circ}$ 9.514/97. Revista da AJURIS, Porto Alegre, v. 26, n. 80, p. 354-376, dez. 2000.

FERRAZ, Patrícia André de Camargo. As novas oportunidades para o advogado, decorrentes do crescimento imobiliário. Revista do Advogado, São Paulo, n. 90, p. 120 127, Mar. 2007.

FIÚZA, César. Alienação fiduciária em garantia de acordo com a Lei no 9.514/97. Rio de Janeiro: Aide, 2000. p. 13-23.

FREITAS, Teixeira de. Código Civil (esboço). Vol. IV. Ministério da Justiça e Negócios Interiores, Brasil, 1952.

FRONTINI, Paulo Salvador. Alienação fiduciária. Revista de Direito Mercantil: industrial, econômico e financeiro., São Paulo, n. 33, p. 100-108, jan./mar. 1979.

GOMES, Orlando. Alienação fiduciária em garantia. São Paulo: Ed. Revista dos Tribunais, $3^{\mathrm{a}}$ ed., rev. e ampl., 1972.

GONÇALVES, Aderbal da Cunha. Da propriedade resolúvel. São Paulo: Editora Revista dos Tribunais, 1979.

HOLDSWORTH, W. S. Historical Introduction to the Land Law. Oxford at the Clarendon Press, 1927.

JACOMINO, Sérgio. Penhora. Alienação fiduciária de coisa imóvel. Algumas considerações sobre o registro. Revista de Direito Imobiliário, São Paulo, n. 59, Jul. / Dez. 2005. 
JOHNSON JR., Alex M., Preventing a return engagement: Eliminating the mortgage purchaser's status as a hold-in-due-course: Properly aligning incentives among the parties, In Pepperdine Law Review, vol. 37, n. 2, 2010.

JOHNSON JR., Alex M., Modern Real Estate, vol. 1, Charlottesville: University of Virginia School of Law, 2011.

JUNQUEIRA DE AZEVEDO, Antonio; TÔRRES, Heleno Taveira; CARBONE, Paolo (coord.), Princípios do Novo Código civil Brasileiro e Outros Temas - Homenagem a Tullio Ascarelli, 2. ed., São Paulo: Quarter Latin, 2010.

LACERDA, Paulo de. Manual do Código Civil Brasileiro: direito das coisas. Vol. VIII. Rio de Janeiro: Jacintho Ribeiro dos Santos, 1924.

LASALVIA, Carlos Virgilio. Do depósito na alienação fiduciária. "O Estado de São Paulo", São Paulo, pág. 58, publicado em 8 dez. 1968. Disponível em: http://acervo.estadao.com.br/pagina/\#!/19681208-28733-nac-0058-999-58not/busca/aliena\%C3\%A7\%C3\%A3o+fiduci\%C3\%A1ria. Acesso em 08 out 2012.

LIMA, Frederico Henrique Viegas de. A circulação do crédito hipotecário no Sistema Financeiro da Habilitação. Revista de Direito Imobiliário, São Paulo, v. 21, n. 43, p. 47 60, Jan. / Abr. 1999.

LIMA, Frederico Henrique Viegas de. Da alienação fiduciária em garantia de bens imóveis (notas para sua estruturação). Revista de Direito Imobiliário, São Paulo, v. 21, n. 44, p. 7 14, Mai. / Ago. 1998.

LIMA, Frederico Henrique Viegas de. Da alienação fiduciária em garantia de coisa imóvel. $2^{\mathrm{a}}$ ed., $3^{\mathrm{a}}$ tiragem. Curitiba: Juruá, 2003.

LIMA, Otto Sousa, Negócio Fiduciário. Tese para concurso à cátedra de Direito Civil da Faculdade de Direito da Universidade de São Paulo. Universidade de São Paulo, São Paulo, 1959, 
LIPARI, Nicolo. Negozio fiduciário. Milano: Giuffre, 1971.

LOPES, Miguel Maria de Serpa, Curso de direito civil: direito das coisas: princípios gerais, posse, domínio e propriedade imóvel, volume VI, 5. ed., rev. e atual., Rio de Janeiro: Freitas Bastos, 2001.

LOUREIRO, José Eduardo. Alienação fiduciária de coisa imóvel. Revista do Advogado, São Paulo, n. 63, p. 86-95, Jun. 2001.

MALUF, Carlos Alberto Dabus, Limitações ao Direito de Propriedade, 3. ed., rev. e atual., São Paulo: Ed. Revista dos Tribunais, 2011.

MARQUES, Cláudia Lima. Contratos no Código de Defesa do Consumidor. $4^{\text {a }}$ ed. São Paulo: Editora Revista dos Tribunais, 2002.

MIRANDA, Custodio da Piedade Ubaldino, Teoria geral do negócio jurídico, 2. ed., São Paulo: Atlas.

MIRANDA, Custódio da Piedade Ubaldino. Negocio jurídico indireto e negócios fiduciários. Revista de Direito Civil, Imobiliário, Agrário e Empresarial, São Paulo, v. 8, n. 29, p. 81-94, Jul. / Set. 1984.

MIRANDA, Pontes de. Tratado de direito privado. Tomos III, IV, V, XXI e LII. $1^{\mathrm{a}}$ ed. Campinas: Bookseller, 2000.

MONTEIRO, Washington de Barros; MALUF, Carlos Alberto Dabus, Curso de Direito Civil, v. 3: direito das coisas, 39. ed., São Paulo, Saraiva, 2009.

MOREIRA ALVES, José Carlos. Da alienação fiduciária em garantia. São Paulo: Saraiva, 1973.

MOREIRA ALVES, José Carlos Moreira. Da alienação fiduciária em garantia, 3. ed., rev., atual. e aum., Rio de Janeiro: Forense, 1987. 
MOREIRA ALVES, José Carlos. Direito Romano. Vol. I. 13ª ed. Rio de Janeiro: Forense, 2004.

MOREIRA ALVES, José Carlos. Da fidúcia romana à alienação fiduciária em garantia no direito brasileiro, In: Cahali, Y. S. (Coord.). Contratos nominados: doutrina e jurisprudência. São Paulo: Saraiva, 1995.

MOURA, Paulo Sérgio. Securitização de créditos imobiliários aspectos jurídicos. 181

p. Dissertação (Mestrado) em Direito. Faculdade de Direito. Universidade de São Paulo (USP). 2007.

NAVARRO MARTORELL, Mariano. La propiedad fiduciaria. La fiducia histórica. Los modernos negocios fiduciarios. Barcelona: Bosch, 1950.

NERY JUNIOR, Nelson. Código brasileiro de defesa do consumidor: comentado pelos autores do anteprojeto. 8. ed., Rio de Janeiro: Forense Universitária, 2005.

NEWMAN, Ralph A. Newman on trusts. 2. ed., Brooklin: The Foundation Press, 1955.

OLIVEIRA NETO, Pedro Cecilio, Alienação fiduciária em garantia. 1. ed., São Paulo: Livraria e Editora Universitária de Direito Ltda., 1975.

PELLEGRINI, Luiz Fernando Gama. Alienação fiduciária - Ação de depósito - Prisão civil - Inadmissibilidade: jurisprudência comentada. Revista dos Tribunais, São Paulo, v. 86, n. 745, p. 111-117, nov. 1997.

PEREIRA, Caio Mário da Silva, Instituições de direito civil, v. 1, Introdução ao direito civil: teoria geral do direito civil, 24. ed., Rio de Janeiro, Ed. Forense, 2011.

PEREIRA, Caio Mário da Silva, Instituições de direito civil, v. 4, Rio de Janeiro: Ed. Forense, 2009. 
PEREIRA, Hélio do Valle, A nova alienação fiduciária em garantia - aspectos processuais, 2. ed., rev., atual., Conceito Editoral, 2008.

PEREIRA, Lafayette Rodrigues. Direito das coisas. Tomo I. $1^{\text {a }}$ ed. Campinas: Russell, 2003.

PINHEIRO, Luís Lima, A cláusula de reserva de propriedade, Coimbra: Livraria Almedina, 1988.

PRATES, Homero. Atos simulados e atos em fraude da lei. São Paulo: Freitas Bastos, 1958.

RABELLO, José Geraldo de Jacobina. Alienação fiduciária em garantia. Revista dos Tribunais, São Paulo, v. 82, n. 693, p. 77-92, jul. 1993.

RESTIFFE NETO, Paulo. Alienação fiduciária imóvel: aspectos processuais. Revista do Advogado, São Paulo, v. 27, n. 90, p. 128-134, Mar. 2007.

RESTIFFE NETO, Paulo. Garantia fiduciária: direito e ações: manual teórico e prático com jurisprudência. $3^{\mathrm{a}}$ ed. rev., atual. e ampl. São Paulo: Editora Revista dos Tribunais, 2000.

RESTIFFE NETO, Paulo; RESTIFFE, Paulo Sérgio, Propriedade fiduciária imóvel, São Paulo: Malheiros Editores, 2009.

REYMOND, Claude. Essai sur la nature et les limites de l'acte fiduciaire. Montreux: Ganguin et Laubscher, 1948.

RIZZARDO, Arnaldo. Contratos. Rio de Janeiro: Forense, 2004.

RIZZARDO, Arnaldo. Direito das coisas. Rio de Janeiro: Forense, 2003. 
ROCHA, Eduardo de Assis Brasil. Algumas considerações sobre a alienação fiduciária de coisa imóvel. Revista de Direito Imobiliário, São Paulo, v. 21, n. 45, p. 95-103, Set. / Dez. 1998.

RODRIGUES Netto, Nelson, A evolução fiduciária em garantia, In: Revista do Curso de Direito do Centro Universitário das Faculdades Metropolitanas Unidas, UniFMU, ano XVIII, nº $26,2004$.

SAAD, Renan Miguel. A alienação fiduciária sobre bens imóveis. Rio de Janeiro: Renovar, 2001.

SALOMÃO NETO, Eduardo. Sistema financeiro imobiliário. Revista de Direito Mercantil, Industrial, Econômico e Financeiro, São Paulo, v. 36, n. 110, p. 155-166, Abr. / Jun. 1998.

SALOMÃO NETO, Eduardo. O trust e o direito brasileiro. São Paulo: Ed. LTR, 1996.

SANTA MARIA, José Serpa de, Curso de direito civil, v. VII: direitos reais limitados, Rio de Janeiro: Freitas Bastos, 1998.

SANTOS, J. M. de Carvalho. Código Civil brasileiro interpretado: parte geral .Vol. II.

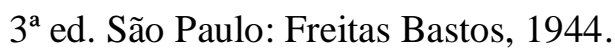

SANTOS, J. M. de Carvalho. Código Civil brasileiro interpretado: direito das coisas. Vol. VIII. Rio de Janeiro: Freitas Bastos, 1988.

SANTOS, Francisco Cláudio de Almeida. A regulamentação da alienação fiduciária de imóveis em garantia. Revista de Direito Bancário e do Mercado de Capitais, São Paulo, v. 2, n. 04, p. 28-36, jan./abr. 1999.

SILVA, Regina Beatriz Tavares da (coord.). Código Civil comentado. Coordenador até a $5^{\mathrm{a}}$ ed. Ricardo Fiuza - $6^{\mathrm{a}}$ ed., rev. e atual.. São Paulo: Saraiva, 2008. 
TÁCITO, CAIO. Alienação fiduciária - código do consumidor - leilão: o art. 27 da lei n. 9.514/97 é compatível com o art. 53 do código de proteção ao consumidor. Revista de Direito Administrativo, Rio de Janeiro, n. 215, p. 291-294, jan./mar. 1999.

TARTUCE, Flávio; SIMÃO, José Fernando. Direito civil, v. 4: Direito das coisas. São Paulo: Método, 2008.

TAVARES, Zilda. Código de Defesa do Consumidor e alienação fiduciária imobiliária. São Paulo: Método, 2005.

TEIXEIRA, Maria P. Q. Brandão; SENISE, Fernando Dizero. Alienação fiduciária em garantia de imóveis. Visão Jurídica, São Paulo, n. 70, fev. 2012. Execução Extrajudicial, p. $10-11$.

TERRA, Marcelo. Alienação fiduciária de imóvel em garantia. Porto Alegre: Safe, 1998.

TREVELIM, Ivandro Ristum. A alienação fiduciária em garantia e sua aplicação no mercado financeiro imobiliário. 213 p. Dissertação (Mestrado) em Direito. Faculdade de Direito. Universidade de São Paulo, 2008.

TRISTÃO, Eduardo. Compromisso de compra e venda: contribuições para o estudo de sua natureza, Revista do Direito Imobiliário, São Paulo, ano 32, n. 67, p-19-69, jul-dez/2009.

VENOSA, Sívio de Salvo, Direito Civil: direitos reais, vol. 5, 7. ed., São Paulo: Atlas, 2007.

VENOSA, Sílvio de Salvo. Direito civil: contratos em espécie, vol. 3. 6 ed. São Paulo: Atlas, 2006.

WALD, Arnoldo. Alguns aspectos do regime jurídico do sistema financeiro imobiliário (lei 9.514/97). Revista de Direito Bancário e do Mercado de Capitais, São Paulo, v. 2, n. 4, p. 13-27, Jan. / Abr. 1999. 
WALD, Arnoldo. Da alienação fiduciária. Revista dos Tribunais, São Paulo, ano 58, v. 400, Fev. 1969.

WALD, Arnoldo. Algumas considerações a respeito da utilização do "trust" no direito brasileiro. Revista de Direito Mercantil Industrial, Econômico e Financeiro, Ed. Revista dos Tribunais, n. 99, julho-setembro/1995, p. 110.

WITZ, Claude. La fiducie en droit privé français. Paris: Econômica, 1981. 